$5_{2}^{0}$

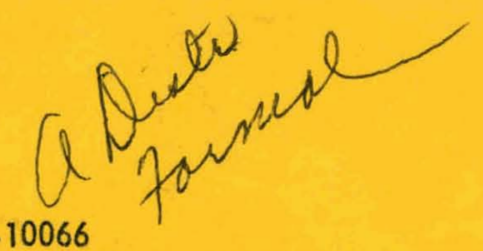

GEAP- 10066

AEC RESEARCH AND

DEVELOPMENT REPORT

JULY 1969

\title{
MECHANICAL PROPERTIES EVALUATION OF AUSTENITIC STAINLESS STEELS IRRADIATED IN EBR-II
}

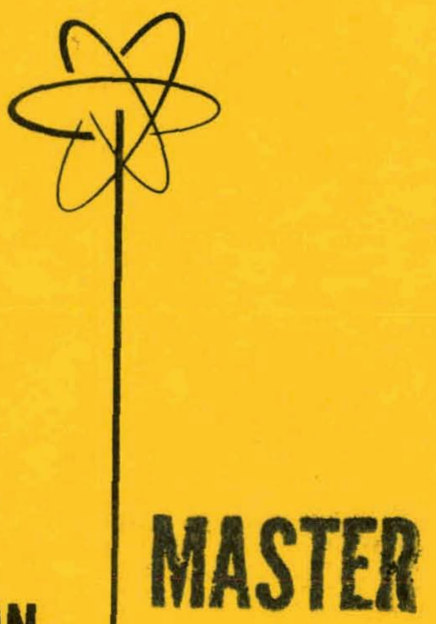

THIS DOCUMENT CONFIRMED AS

T. LAURITZEN

A. WITHOP

G.P. FERGUSON

DIVISION OF CLASSI ICATION

BY

DATE

U.S. ATOMIC ENERGY COMMISSION

CONTRACT AT(04-3)-189

PROJECT AGREEMENT 10

BREEDER REACTOR DEVELOPMENT OPERATION

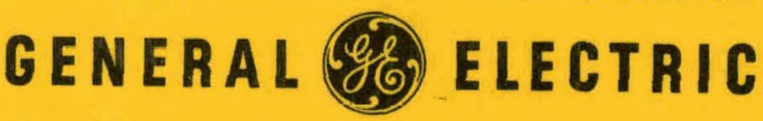

SUNNYVALE, CALIFORNIA 


\section{DISCLAIMER}

This report was prepared as an account of work sponsored by an agency of the United States Government. Neither the United States Government nor any agency Thereof, nor any of their employees, makes any warranty, express or implied, or assumes any legal liability or responsibility for the accuracy, completeness, or usefulness of any information, apparatus, product, or process disclosed, or represents that its use would not infringe privately owned rights. Reference herein to any specific commercial product, process, or service by trade name, trademark, manufacturer, or otherwise does not necessarily constitute or imply its endorsement, recommendation, or favoring by the United States Government or any agency thereof. The views and opinions of authors expressed herein do not necessarily state or reflect those of the United States Government or any agency thereof. 


\section{DISCLAIMER}

Portions of this document may be illegible in electronic image products. Images are produced from the best available original document. 
GEAP-10066

AEC Research and

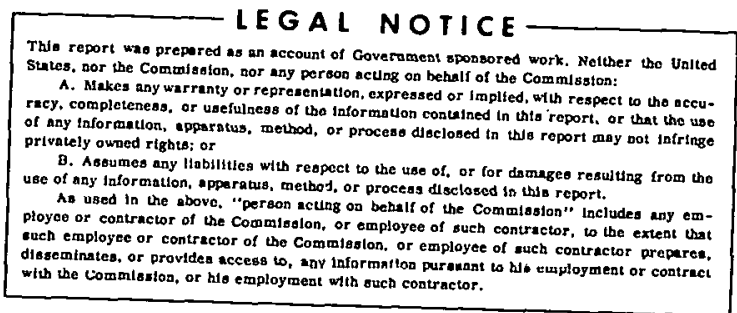

\section{MECHANICAL PROPERTIES EVAI,UATION OF AUSTENITIC STAINLESS STEELS IRRADIATED IN EBR-II}

\section{T. Lauritzen}

A. Withop

G.P. Ferguson

Approved:

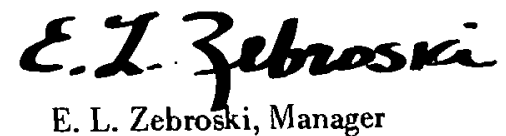

Sodium Reartor Teshnology
Approved:

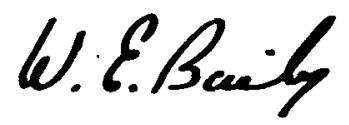

W. E. Baily, Project Engineer Fast Ceramic Reactor Development Program

Prepared for the

U. S. Atomic Energy Commission

Under Contract Number AT(04-3)-189

Project Agreement 10

Printed in U.S. A. Available from the Clearing House for Federal Scientific and Technical Information National Bureau of Standards, U.S. Department of Commerce

Springfield, Virginia

Price: $\$ 3.00$ per copy

\section{BREEDER REACTOR DEVELOPMENT OPERATION \\ GENERAL ELECTRIC \\ SUNNYVALE, CALIFORNIA}




\section{LEGAL NOTICE}

This report was prepared as an account of Government sponsored work. Neither the United States, nor the Commission, nor any person acting on behalf of the Commission:

A. Makes any warranty or representation, expressed or implied, with respect to the accuracy, completeness, or usefulness of the information contained in this report, or that the use of any information, apparatus, method, or process disclosed in this report may not infringe privately owned rights; or

B. Assumes any liabilities with respect to the use of, or for dam. ages resulting from the use of any information, apparatus, method, or process disclosed in this report.

As used in the above, "person acting on bebalf of the Commission" includes any employee or contractor of the Commission, or employee of such contractor, to the extent that such employee or contractor of the Commission, or employee of such contractor prepares, disseminates, or provides access to, any information pursuant to bis employment or contract with the Commission, or bis emplovment witb such contractor. 


\section{TABLE OF CONTENTS}

Abstract ......................... - . 1-

1. Summary .......................... . . . 1-

2. Conclusions . . . . . . . . . . . . . . . . . . 2 -

3. Introduction . . . . . . . . . . . . . . . . . . - 2

4. Experimental Procedure . . . . . . . . . . . . . . . . -2-

4.1 Materials .. . . . . . . . . . . . . . . . . . -2

4.2 Irradiation Capsule . . . . . . . . . . . . . . . . . -17-

4.3 History of Irradiation . . . . . . . . . . . . . . . . . - 17-

4.3.1 EBR-II History . . . . . . . . . . . . . . . . . . . . . -17-

4.3.2 Dosimetry . . . . . . . . . . . . . . . . . . -18-

4.3.3 Evaluation of Temperature During Exposure . . . . . . . - 18-

5. Results ... . . . . . . . . . . . . . . . . . 37 -

5.1 In-Reactor Deformation . . . . . . . . . . . . . . . -37-

5.2 Burst Tests on EBR-II Capsule Tubes . . . . . . . . . . . . . . . 37-

5.2.1 Test Procedure . . . . . . . . . . . . . . . . . . . . . 46 .

5.2.2 Results and Discussion . . . . . . . . . . . . . . . . 46 -

5.3 Tensile Evaluation . . . . . . . . . . . . . . . . . . -56 -

5.3.1 Properties of Alloys in the Mill-Annealed Condition . . . . . $\quad-56$ -

5.3.2 Propertics of Alloys in the Carbidc-Agglomeratcd Condition . . 75

Appendix ......................... 81 - .

References ....................... ${ }^{85}$

Acknowledgments . . . . . . . . . . . . . . . . 85 -

Distribution ..................... ${ }^{85}$ 


\section{LIST OF ILLUSTRATIONS}

4-1 Flow Diagram for Fabrication of Tensile Samples from Commercial Tube . . . . . . . . - 5-

4.2 Tensile Coupon . . . . . . . . . . . . . . . . . . . 6-

4-3 Microstructure of Type-304 Stainless Steel, Mill Annealed.

Etchant: $\mathrm{HCl}+\mathrm{H}_{2} \mathrm{O}_{2}$ (Reduced to $\sim 75 \%$ for

reproduction purposes) . . . . . . . . . . . . . . . . 7-

4-4 Microstructure of Type-304 Stainless Steel, Carbide Agglomerated.

Elchant: Modified Glyceregia (Reduced to $\sim 75 \%$ for reproduction

purposes) ....................... . . . . . . .

4.5 Microstructure of Type-316L Stainless Steel, Mill Annealed.

Etchant: $\mathrm{HCl}+\mathrm{H}_{2} \mathrm{O}_{2}$ (Reduced to $\sim 75 \%$

for reproduction purposes) . . . . . . . . . . . . . . . . . .9-

4-6 Microstructure of Type-316 Stainless Steel, Carbide Agglomerated.

Etchant: Modified Glyceregia (Reduced to $\sim 75 \%$ for reproduction

purposes)

4-7 Microstructure of Type-321 Stainless Steel, Mill Annealed.

Etchant: $\mathrm{HCl}+\mathrm{H}_{2} \mathrm{O}_{2}$ (Reduced to $\sim 75 \%$

for reproduction purposes) . . . . . . . . . . . . . - 11-

4-8 Microstructure of Type-321 Stainless Steel, Carbide Agglomerated.

Etchant: Modified Glyceregia (Reduced to $\sim 75 \%$ for reproduction

purposes)

4-9 Microstructure of Type-347 Stainless Steel, Mill Annealed. Etchant:

$\mathrm{HCl}+\mathrm{H}_{2} \mathrm{O}_{2}$ (Reduced to $\sim 75 \%$ for

reproduction purposes)

4-10 Microstructure of Type-347 Stainless Steel, Carbide Agglomerated.

Etchant: Modified Glyceregia (Reduced to $\sim 75 \%$ for reproduction

purposes)

4-11 Microstructure of Incoloy 800, Mill Annealed. Etchant: 10\% Oxalic

Acid-Tubular Coupon, $\mathrm{HCl}+\mathrm{H}_{2} \mathrm{O}_{2}$-Tensile Coupon

(Reduced to $\sim 75 \%$ for reproduction purposes)

4-12 Microstructure of Incoloy-800, Carbide Agglomeraled. Etchant: 10\%

Oxalic Acid (Reduced to $\sim 75 \%$ for reproduction purposes) . . . . . . . . . . . . . -16 .

4-13 Series L-2' Irradiation Capsule: Assembly . . . . . . . . . . . . . . . . . . .

4-14 Series L-2' Irradiation Capsule: Test Specimen . . . . . . . . . . . . . . . 21-

4-15 Series L-2' Irradiation Capsule: Sentinel . . . . . . . . . . . . . . . . . 22- 


\section{LIST OF ILLUSTRATIONS (Continued)}

Figure

Title

4-16 Series L-4/L-4' Irradiation Capsule: Assembly . . . . . . . . . . . . . . . . . . . -23-

4-17 Series L-4/L-4' Irradiation Capsule: Test Specimen ～. . . . . . . . . . . . . . . . -25-

4-18 Series L-4/L-4' Irradiation Capsule: Sentinel _. . . . . . . . . . . . . . . . . . . - 26-

4-19 EBR-II Loading Pattern . . . . . . . . . . . . . . . . . . . . . . . . . . -27.

4-20 Subassembly Diagram, XG06 . . . . . . . . . . . . . . . . . . . . . . . . 28.

4-21 Subassembly Diagram, X009 . . . . . . . . . . . . . . . . . . . . . . 29.

4-22 Subassembly Diagram, X014 . . . . . . . . . . . . . . . . . . . . . . .30.

4-23 EBR-II Neutron Fluence Distribution for Capsule Series L-2, L-4, and L.4' . . . . . . . . $\quad .8 .3$

4-24 Temperature Distribution in Materials Capsule L4B . . . . . . . . . . . . . . . . . . 34

4-25 Metallographic Cross Section, L4F-4 . . . . . . . . . . . . . . . . . . . . . . . -35-

4-26 Metallographic Cross Section, L20-2 . . . . . . . . . . . . . . . . . . . . . . . -36-

5-1 Post-Irradiation Profilometer Tracc for Tubular Test Section L-4A-1

(Incoloy 800) . . . . . . . . . . . . . . . . . . . . . . . -40

5-2 Post-Irradiation Profilometer Trace for Tubular Test Section L-4A-4

(Incoloy-800) . . . . . . . . . . . . . . . . . . . . . . . 41

5-3 Photomicrographs of Failed Tubular Test Section L-4C-4 (Typc 316)

Transverse Section . . . . . . . . . . . . . . . . . . . . . . . . . . . . . . 42

5-4. Transverse Section of Tubular Test Section L-4C-4 (Type 316) Seam Weld Region . . . 43

5-5 Expoouro History of F2 Capsule Tulies in EBR-II . . . . . . . . . . . . . . . . . -44-

5-6 Microstructure of Type-304 Capsule Tubes Used in FCR Fuels Irradiation

Capsule Serics F2 . . . . . . . . . . . . . . . . . . . . . . . . . . . . . 45-

5.7 Dynamic Burst Apparatus . . . . . . . . . . . . . . . . . . . . . . . . . . . . . . . 47

5-8 Rupture Characteristics of Irradiated Type-304 Burst Specimens . . . . . . . . . . . -48-

5-9 Rupture Characteristics of Unirradiated Type-304 Burst Specimens . . . . . . . . . . 49-

5-10 Microstructure of Representative Control Specimens, Annealed. Burst

Temperature was $900^{\circ} \mathrm{F}$. . . . . . . . . . . . . . . . . . . . . . . 50 -

5-11 Effect of Post-Irradiation Test Temperature on Burst Strength of Type-304

'Tubing ....... . . . . . . . . . . . . . . . . . . 


\section{LIST OF ILLUSTRATIONS (Continued)}

\section{Figure}

Title

5-12 Effect of Irradiation on High Temperature Rupture Strength of Type-304

Tubing. Comparison with other data . . . . . . . . . . . . . . . . . . 52 -

5-13 Effect of Irradiation on the High-Temperature Ductility of Type-304 Tubing . . . . - . - -53-

5-14 Effect of Fluence and Test Temperature on Rupture Strength of Type-304 Tubing . . . -61-

5-15 Radiation Strengthening of Austenitic Stainless Steel at $1300^{\circ} \mathrm{F}$ versus Fluence . . . . . . . . . . . . . . . . . . . . . . . . 62 .

5-16 Radiation Embrittlement of Austenitic Stainless Steel at $1300^{\circ} \mathrm{F}$ versus Fluence . . . . . . . . . . . . . . . . . . . . . 62 -

5-17 Temperature Dependence of Type 304 Tensile Properties _ . . . . . . . . . . . . . . -63-

5-18 Temperature Dependence of Type 316L Tensile Properties ～. . . . . . . . . . . . . -64-

5-19 Temperature Dependence of Type 321 Tensile Properties . . . . . . . . . . . . . . -65-

5-20 Temperature Dependence of Type 347 Tensile Proptrties . . . . . . . . . . . . . . . -66-

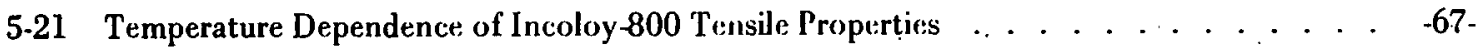

5-22 Rate Dependence of $1300^{\circ} \mathrm{F}$ Tensile Properties for Type $304 \ldots$. . . . . . . . . . . . . -

5-23 Rate Dependence of $1300^{\circ} \mathrm{F}$ Tensile Properties for Type 316L _ . . . . . . . . . . . . . . $\quad-69$.

5-24 Rate Dependence of $1300^{\circ} \mathrm{F}$ Tensile Properties for Type $321 \ldots$. . . . . . . . . . . . $\quad-70$

5-25 Rate Dependence of $1300^{\circ} \mathrm{F}$ Tensile Properties for Tym: $347 \quad$. . . . . . . . . . . . . .

5-26 Rate Dependence of $1300^{\circ} \mathrm{F}$ Tensile Properties for Incoloy $800 \quad \ldots \quad$. . . . . . . . .

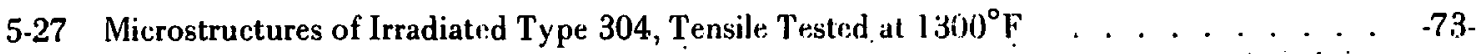

5-28 Effect of Strain Rate on the $1300^{\circ} \mathrm{F}$ Flow Curves of Mill-Anneaded Type 304 , Irradiated at $>1220^{\circ} \mathrm{F}$ to $6.2 \times 10^{21}\left(\mathrm{E}_{\mathrm{n}}>1 \mathrm{M}: \mathrm{V}\right) \quad$. . . . . . . . . . . . -74-

5-29 Transmission Electron Micrograph from Gage Section of Failed Specimen* No. 218 (Mill-Annealed Type 304) _. . . . . . . . . . . . . . . . . . . . . . 76 -

5-30 Surface Microstructure of Failed Specimen No. 218 (Mill-Anmealeal Type 304) . . . . . - -76-

5-31 Surface Microstructure of Failed Specinen No. 211 (Mill-Annealed Type 304) . . . . . 77.

5-32 Post-Irradiation Strain Properties of Type: 304 at $1300^{\circ} \mathrm{F}$ verius Fluence . . . . . . . . . . . . . . . . . . . . . . . 78 


\section{LIST OF ILLUSTRATIONS (Continued)}

Figure

Title

5-33 Comparison of Microstructure for (a) Mill-Annealed and (b) Carbide-Agglomerated

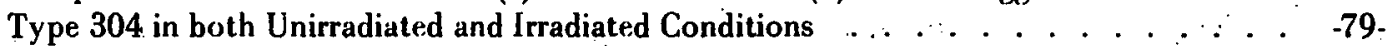

5-34 Replica Electron Micrographs of (a) Arnealed, and (b) Carbide-Agglomerated Type 304 Irradiated in EBR.II

\section{LIST OF TABLES}

Table

Title

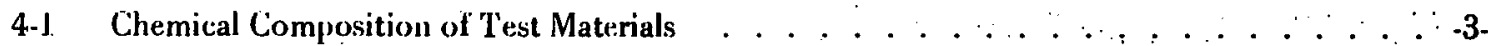

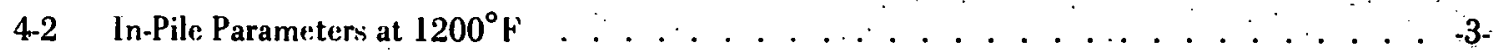

4-3 Summary of 'Temperature Monitor Data $\ldots \ldots \ldots \ldots \ldots \ldots \ldots \ldots \ldots \ldots$

5-1 Diametral Growth of Tubular $\mathrm{T}$ est Sections From Series L-2' $\quad \ldots \ldots \ldots \ldots$

5-2 Diametral (Growth of T'ubular Test Sertions From Series L-4 and L-4' $\ldots \ldots$. . . . . .

5-3 Certified Chemistry of Type-304 Capsule Tube . . . . . . . . . . . 46-

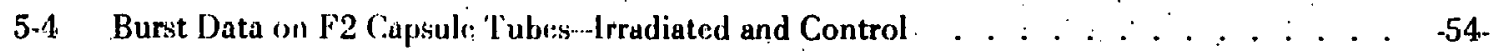

5-5 Post-Burst Diamelral (Changes In Control and Irradiated Type-304 Tubing ． . . . . . . $\quad-55$

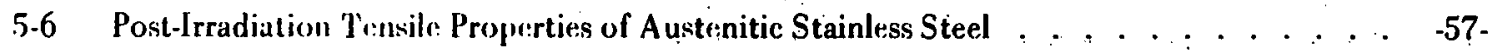




\begin{abstract}
Tensile coupons of five austenitic materials (Types 304, 316, 321, 347 and Incoloy-800) prepared from thin-wall tubing were irradiated in EBR-II. The maximum accumulated neutron exposure was $3.4 \times 10^{22} \mathrm{n} / \mathrm{cm}^{2}$, total, at temperatures ranging from 1000 to $1300^{\circ} \mathrm{F}$. The mechanical properties of the irradiated coupons were determined; the results are reported here. Fost-irradiation mechanical testing included uniaxial tensile and burst (biaxial) tests at temperatures ranging from 900 to $1500^{\circ} \mathrm{F}$. Light optical and. electron metallography studies were conducted to characterize the mode of failure.

Heat treatment for Type-304 stainless steel to produce a "carbide agglomerated" state was found to promote increased residual ductilities after reactor exposure. This observation, which need's confirmation, is in contrast to larger reductions in ductility (measured by percent elongation) found for all five commercial austenitic alloys used in these experiments in the as-received or mill-annealed condition.
\end{abstract}

\title{
1. SUMMARY
}

This report describes the first phase of a comprehensive experimental program directed toward the characterization of the effects of irradiation on austenitic stainless steels. This work complements the irradiation testing of fuel pins in that it permits assessment of a greater number of variables-as well as isolation of some variables-than pin testing. The ultimate objective of this work is the selection of the most appropriate austenitic alloy for use in a sodium-cooled fast breeder reactor as cladding for mixed urania-plutonia fuel. Of particular importance in this application is the degradation in mechanical properties due to long-term exposure to high fast-neutron fluxes at elevated temperatures. The work discussed here was designed to establish the magnitude of damage incurred under these. conditions.

Five austenitic alloys-Types 304, 316, 321, 347 and Incoloy-800-were irradiated as tubular and sheet tensile specimens in EBR-II. Two microstructures were investigated: Annealed (pre-irradiation microstructure free of intergranular carbides), and carbide-agglomerated (preirradiation microstructure consisting of large discrete intergranular carbides). The capsules containing these specimens accumulated maximum fluences ranging from 1.7 to $3.4 \mathrm{X}$ $10^{22} \mathrm{n} / \mathrm{cm}^{2}\left(\mathrm{E}_{\text {Total }}\right)$ at temperatures as high as $1300^{\circ} \mathrm{F}$. Post-irradiation examination of these specimens included metallography to establish the effect of irradiation on alloy microstructure, and uniaxial and biaxial mechanical properties tests to assess the magnitude of damage.

Tensile test results showed that, within the neutron fluence range investigated, all annealed materials exhibited decreases in total strain with increasing fluence and decreasing strain rate. For Types 304 and $316 \mathrm{~L}$, total strains recorded were in the range of 3.6 to $7.7 \%$, while those for
Types 321,347 , and Incoloy-800 were 1.0 to $5.8 \%$. Total strain values for all unirradiated materials in the annealed condition were 30 to $44 \%$ at $1300^{\circ} \mathrm{F}$. In the carbide ag. glomerated condition, Type-304 stainless steel exhibits an increase in fracture strain. Although this observation is encouraging, it needs further confirmation before it acquires enough significance to be considered in the selection of an appropriate fuel cladding.

Significant increases in yield strength were noted for all materials with the strengthening effect increasing with fluence, except for Incoloy-800 which remains relatively constant. The degree of strengthening decreased with test temperature, with recovery occurring at 1500 to $1600^{\circ} \mathrm{F}$ for all alloys.

Elevated temperature bursting of tubular specimens revealed substantial increases in burst strength and reductions in circumferential ductility with irradiation. At a test temperature of $1300^{\circ} \mathrm{F}$, the core and blanket specimens exhibited increases in burst strength to $40 \%$ and $17 \%$, respectively, relative to unirradiated annealed specimens. This disparity diminishes with increasing test temperature, and indicates complete recovery at approximately $1600^{\circ} \mathrm{F}$.

The effects of carbide morphology and distribution on the embrittlement of Type 304 during irradiation was also investigated. In the annealed (unirradiated) condition, the alloy was free of grain-boundary carbides, but exhibited a continuous grain-boundary precipitation after irradiation. In the carbide-agglomerated condition, the microstructure consisted of large, discrete intergranular carbides both before and after irradiation. Post-irradiation results at $1300^{\circ} \mathrm{F}$ indicate that specimens in both structural conditions were embrittled; however, the carbide-agglomerated material showed a lower degree of embrittlement. 


\section{CONCLUSIONS}

Specimens of five austenitic alloys (304, 316, 321, 347, and incoloy-800) were irradiated in EBR-II to accumulated fluences of up to $3.4 \times 10^{22} \mathrm{n} / \mathrm{cm}^{2}$ (total) and peak temperatures as high as $1300^{\circ} \mathrm{F}$. Post-irradiation examination of both strip tensile and tubular specimens yielded the following results:

a. Embrittlements ranging from 70 to $98 \%$, as monitored by reduction in total tensile strain, were measured on all alloys investigated.

b. Intergranular carbides of the morphology and distribution found in carbidc-agglomcratcd materials caused an increase in total tensile elongation of irradiated Type-304 stainless steel. (This observation, however, requires further confirmation before carbide agglomeration can be considered as a specification for LMFBR cladding.)

c. Except for Incoloy 800 , all alloys tested after irradiation exhibited increases in yield strength. The degree of strengthening was reduced by postirradiation annealing, with full recovery occurring between 1500 and $1600^{\circ} \mathrm{F}$. However, most of the embrittlement remained.

d. The yield strengths of all irradiated alloys were observed to vary with the strain rate used in tensile testing. A reduction in strain rate caused a corresponding reduction in yield.

\section{INTRODUCTION}

Current fuel cladding designs for a Liquid Metal Fast Breeder Reactor (LMFBR) call for cladding to operate with (a) fast-neutron fluxes near $10^{16} \mathrm{n} / \mathrm{cm}^{2}-\mathrm{sec}$, (b) total fluences over $10^{23} \mathrm{n} / \mathrm{cm}^{2}$, (c) peak cladding temperatures up to $1300^{\circ} \mathrm{F}$, (d) a variety of stress systems arising from fuel swelling, clad swelling, fission-gas pressure, thermal gradients, and power and temperature cycling, and (e) close contact with fuel and flowing sodium.
Thus far, the austenitic stainless steels are considered to be the most promising cladding materials for the first generation of LMFBR's. Those alloys receiving attention in this program are Type 304, Type 316, Type 321, Type 347, and Incoloy 800 . The objective of this report is to describe the irradiation history and the post-irradiation mechanical and physical properties of these alloys, exposed as tensile specimens in the Experimental Breeder Reactor No. II (EBR-II).

\section{EXPERIMENTAL PROCEDURE}

\subsection{MATERIALS}

These experiments comprised three subassemblies irradiated in EBR-II. A total of 12 materials capsules were incorporated into these subassemblies. Series $\mathrm{L}-2^{\prime}$ contained five capsules, one each of five commercial alloys of austenitic stainless steel: Types 304, 316L, 321, 347, and Incoloy-800. Type 316 was used exclusively in the two capsules of series L4. The five materials capsules irradiated in series $L-4{ }^{\prime}$ were fabricated from Incoloy-800 (2 capsules), and Types 304, 321, and 347 (one capsule of each). All alloys were purchased as welded and drawn tubing. The chemical compositions of the six alloys used in. this investigation are listed in Table 4-1.

The test section material was irradiated in two configurations: thin-wall tubing and thin-sheet tensile coupons. Two structural conditions were studied: mill annealed and carbide agglomerated. The mill-annealed structure is defined as the as-received condition; the carbide-agglomerated structure was developed by heat- treating as-received material at $1650^{\circ} \mathrm{F}$ for 24 hours in a helium atmosphere. The heat-treatment schedule for tensile coupons is shown in Figure 4-1. Tensile coupons were fabricated from flattened tubing and stamped out to conform to the dimensions shown in Figure 4-2. Microstructure of the materials prior to irradiation are shown in Figures 4-3 through 4-12. Transverse sections of tubular samples and longitudinal sections of tensile coupons were selected to show the material structure in the direction corresponding to the direction of principal stress during subsequent mechanical testing.

Type 304 microstructures are seen in Figures 4.-3 (mill-annealed) and 4-4 (carbide-agglomerated). The grain size is ASTM 7 to 8 . Slight grain growth occurred in the tensile coupon, resulting from the $1800^{\circ} \mathrm{F}$ anneal given to the coupon after flattening and stamping.

The mill-annealed Type 316L (Figure 4-5) has a grain size of ASTM 7; the grain size in the weld region is somewhat finer (not fully recrystallized). A duplex grain 
TABLE 41

CHEMICAL COMPOSITION OF TEST MATERIALS

\begin{tabular}{|c|c|c|c|c|c|c|c|c|c|c|c|c|c|c|c|}
\hline Alloy & Heat No. & $\mathbf{N i}$ & $\mathrm{Cr}_{r}$ & $\mathbf{F e}$ & C & $\mathbf{M n}$ & Si & Cu & Mo & $\mathbf{P}$ & s & $\mathbf{B}^{*}$. & $\mathrm{N}^{*}$ & Other & \\
\hline Type 304 & 125653 & 9.15 & 18.42 & Balance & 0.06 & 1.55 & 0.41 & 0.27 & 0.50 & 0.025 & 0.010 & 16 & 540 & & \\
\hline Type 316 & 850145 & 13.16 & 17.63 & Balance & 0.04 & 1.90 & 0.52 & 0.16 & 2.81 & 0.021 & 0.006 & 7.8 & 630 & & 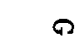 \\
\hline Type 316L & 133310 & 13.31 & 17.39 & Balance & 0.02 & 1.80 & 0.66 & 0.07 & 2.20 & 0.017 & 0.008 & 9.5 & 500 & & 5 \\
\hline Type 321 & 800738 . & 9.53 & 17.13 & Balance & 0.05 & 1.35 & 0.64 & 0.16 & 0.29 & 0.019 & $0.0 \mathrm{rl}$ & 18.5 & 110 & $0.53 \mathrm{Ti}$ & 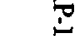 \\
\hline Type 347 & 99973 & 9.32 & 18.20 & Balance & 0.05 & 1.16 & 0.72 & 0.20 & 0.14 & 0.023 & 0.009 & 12.0 & 560 & $0.91 \mathrm{Cb}+\mathrm{Ta}$ & 8 \\
\hline Incoloy -800 & 4167 & 32.00 & 20.44 & 46.09 & 0.05 & 0.99 & 0.25 & 0.33 & N.D: & N.D. & 0.007 & 12 & 930 & $0.5 \mathrm{l} \mathrm{Ti}+0.40 \mathrm{Al}$ & হু \\
\hline
\end{tabular}

* Impurities in ppm. 
TABLE 4-2

IN-PILE STRESS PARAMETERS AT $1200^{\circ} \mathrm{F}$

Test Material

Type 304

Type 316L

Type 316

Type 321

Type 347

Incoloy -800
- In-Pile Stress Level

(psi)

8,000

9,000

13,000

10,000

12,000

12,000 
STARTING MATERIAL

0.0250-inch-0.d. x 0.015-inch-WALL TUBING

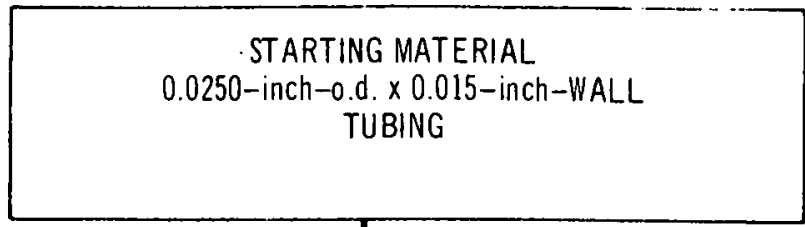

ANNEALED AT $1800^{\circ} \mathrm{F} i$

SLIT AND FLATTENED TUBING

MILL-ANNEALED

15 MINUTES,AIR-COOLED

\section{PUNCHED-OUT TENSILE}

SAMPLES TO CONFORM TO

FIGURE 4-2

ANNEALED AT $1650^{\circ} \mathrm{F} /$

24 HOURS,AIR-COOLED

CARBIDE-AGGLOMERATED SAMPLES

Figure 4-1. Flow Diagram for Fabrication of Tensile Samples from Commercial ''ube 


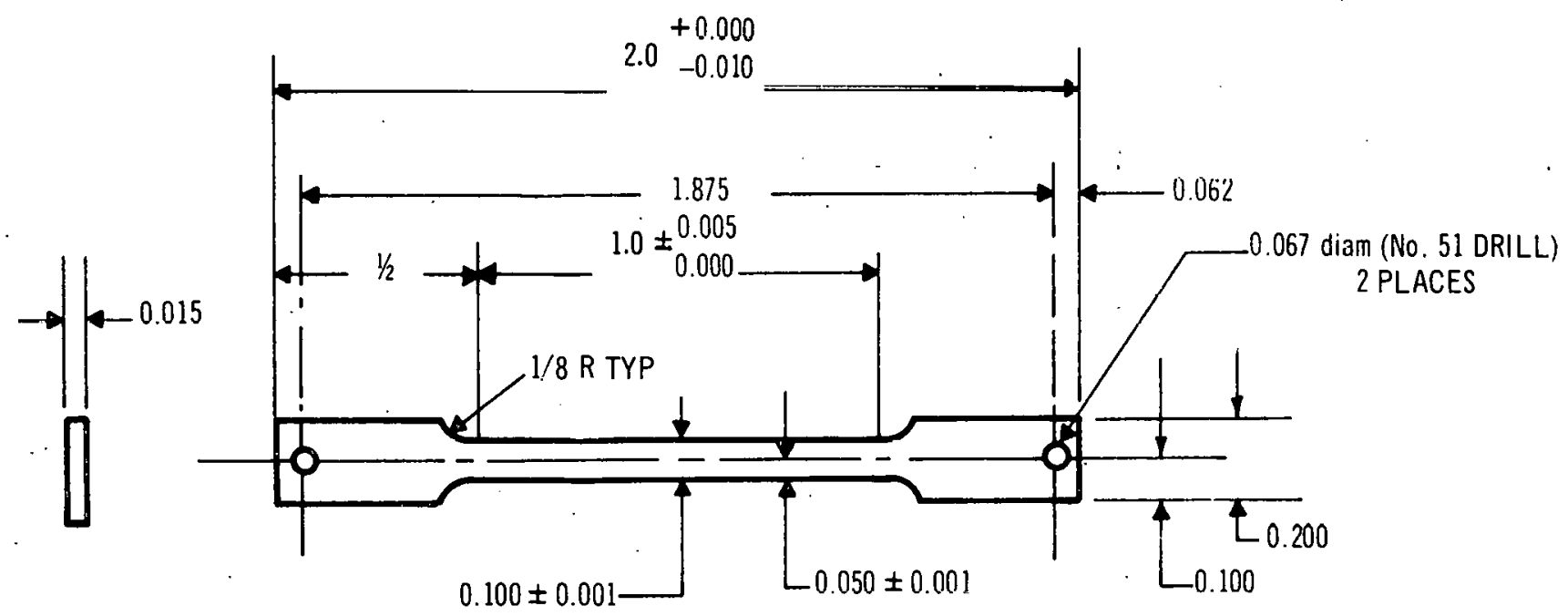

SURFACES: 63

TOLERANCES ON MACHINED DIMENSIONS:

r RACTIONS- $\pm 1 / 32$

DECIMALS - \pm 0.010

Figure 4-2. Tensile Coupon

$-6$ 
TUBULAR COUPON

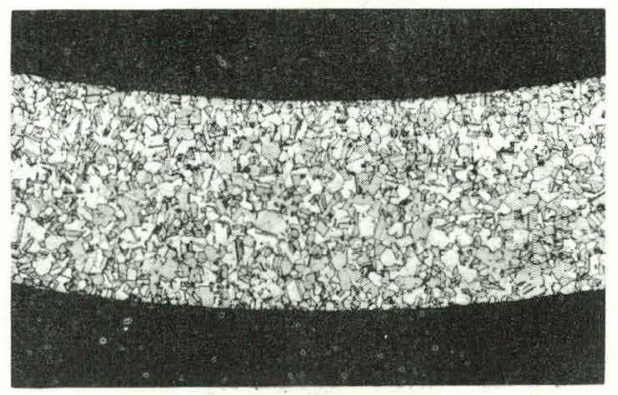

SECTION: TRANSVERSE MAGNIFICATION: $100 \mathrm{X}$

ATSM GRAIN SIZE NO。 7

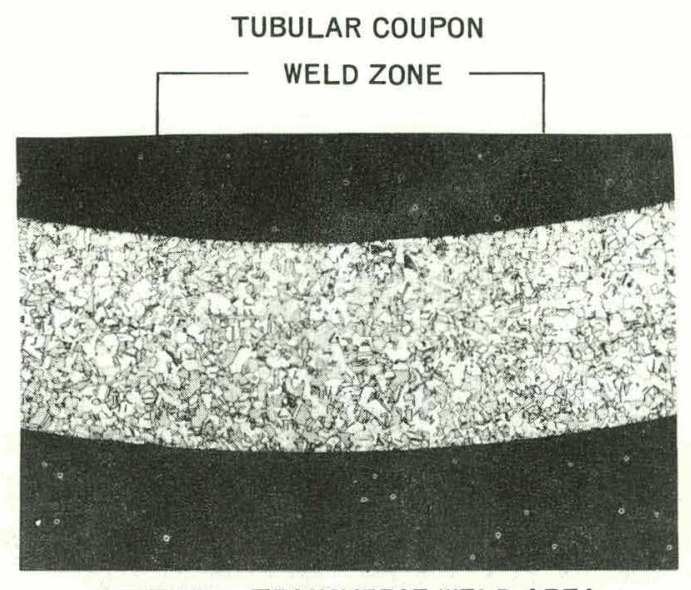

SECTION: TRANSVERSE-WELD AREA MAGNIFICATION: $\quad 100 \mathrm{X}$

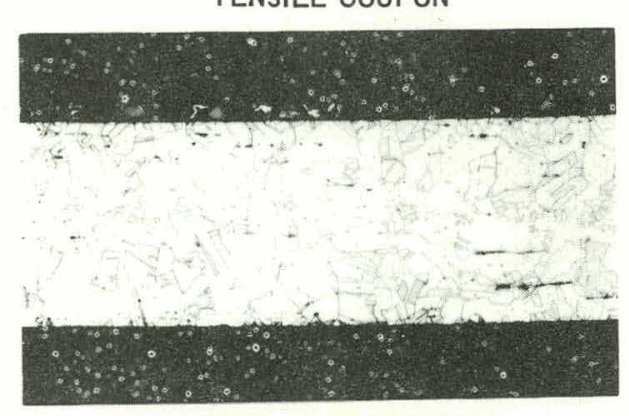

SECTION: LONGITUDINAL

MAGNIFICATION: $\quad 100 \mathrm{X}$

ATSM GRAIN SIZE NO. 6
TUBULAR COUPON

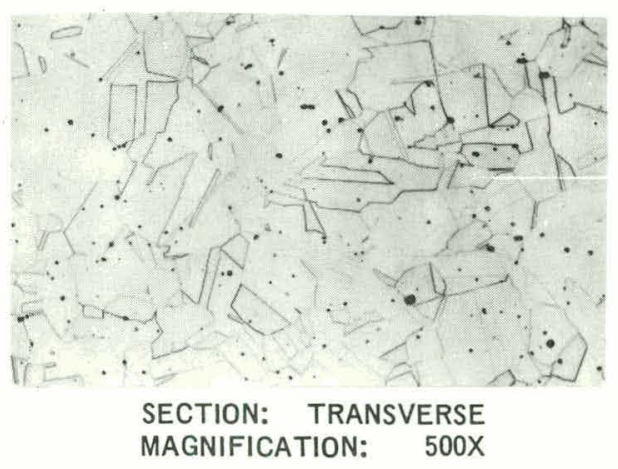

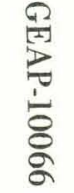

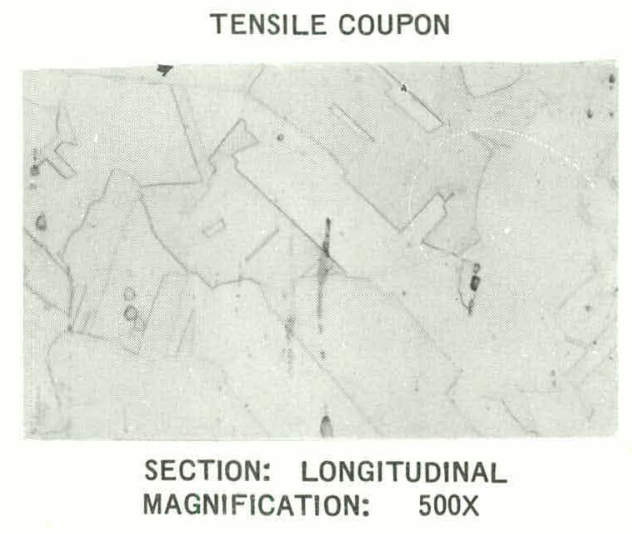

Figure 4-3. Microstructure of Type-304. Stainless Steel, Mill Annealed. Etchant: $\mathrm{HCl}+\mathrm{H}_{2} \mathrm{O}_{2}$ (Reduced to $\sim 75 \%$ for reproduction purposes) 
TUBULAR COUPON

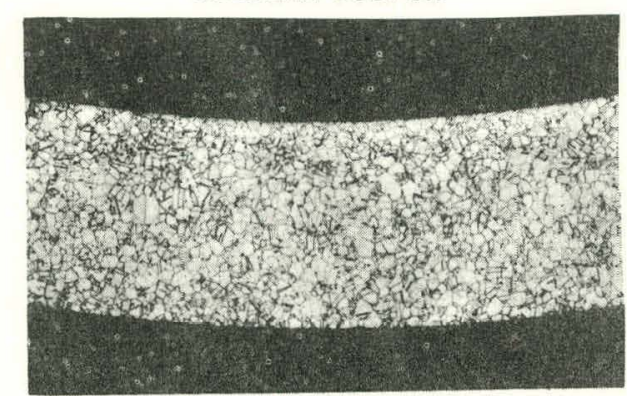

SECTION: TRANSVERSE MAGNIFICATION: 100X

ASTSM GRAIN SIZE NO. 8

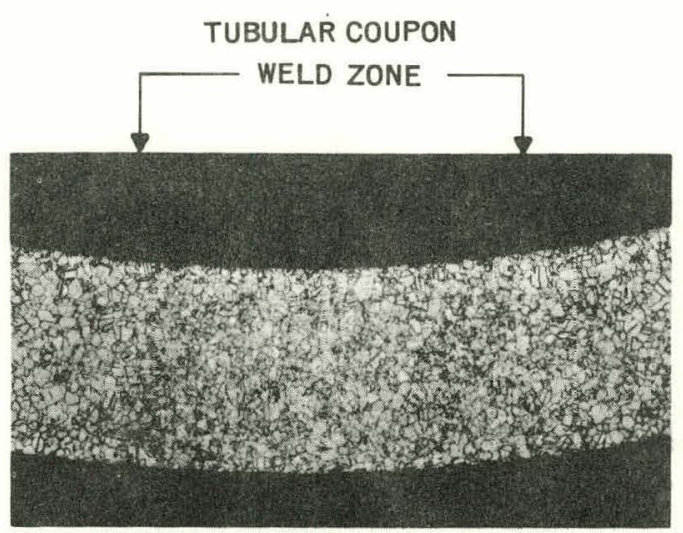

SECTION: TRANSVERSE-WELD AREA MAGNIFICATION:

$$
100 \mathrm{X}
$$
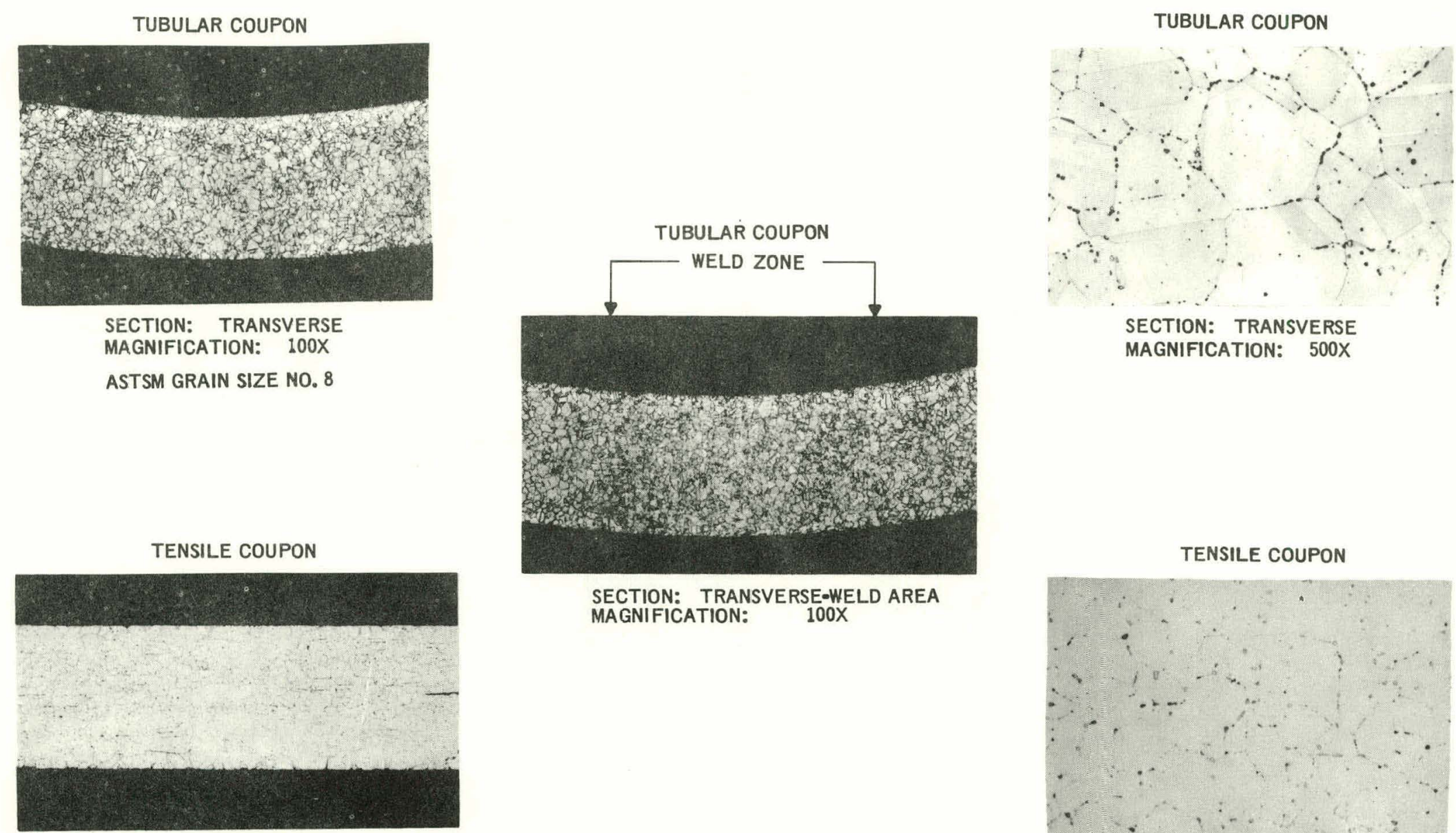

SECTION: LONGITUDINAL

MAGNIFICATION:

$100 \mathrm{X}$

ATSM GRAIN SIZE NO. 7

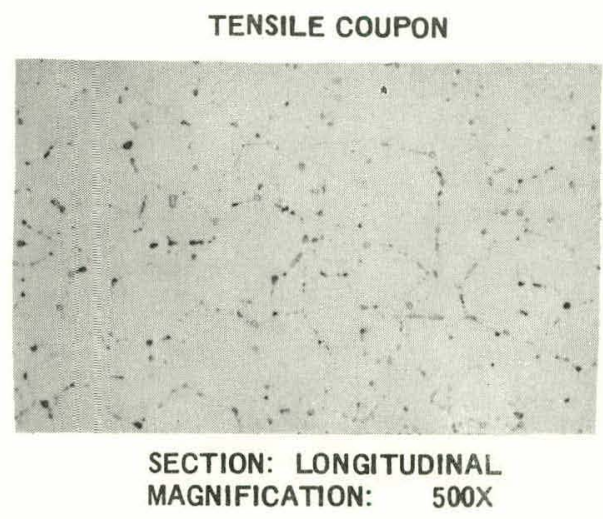

Figure 4-4. Microstructure of Type-304 Stainless Steel, Carbide Agglomerated. Etchant: Nrodified Glyceregia (Reduced to $\sim 75 \%$ for reproduction purposes) 
TUBULAR COUPON
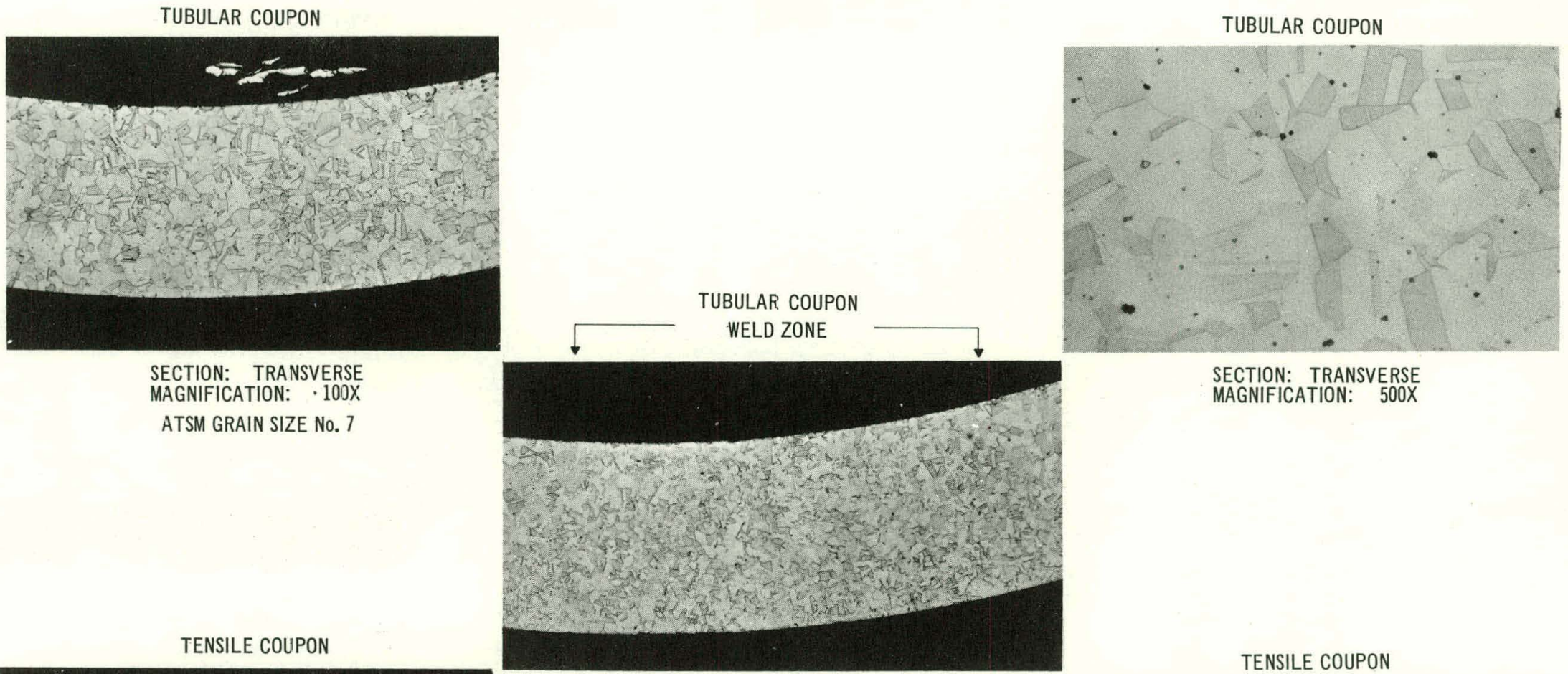

SECTION: TRANSVERSE

MAGNIFICATION: ' $100 X$

ATSM GRAIN SIZE No. 7

TENSILE COUPON

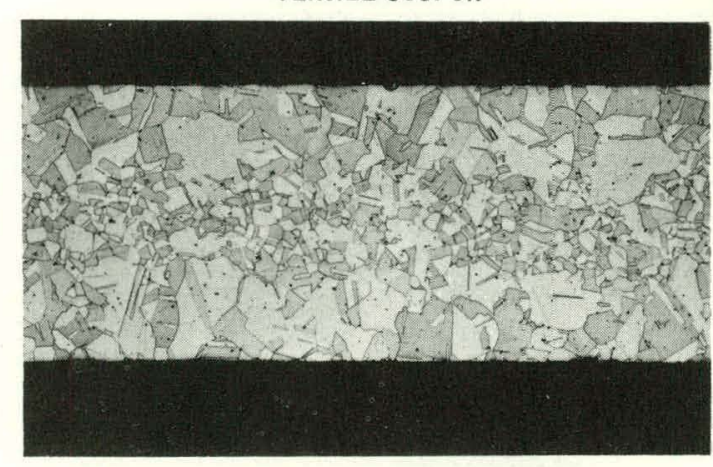

SECTION: LONGITUDINAL MAGNIFICATION: $\quad 100 \mathrm{X}$
SECTION: TRANSVERSE-WELD AREA MAGNIFICATION:

\section{$\leftarrow$ DUPLEX GRAIN SIZE}

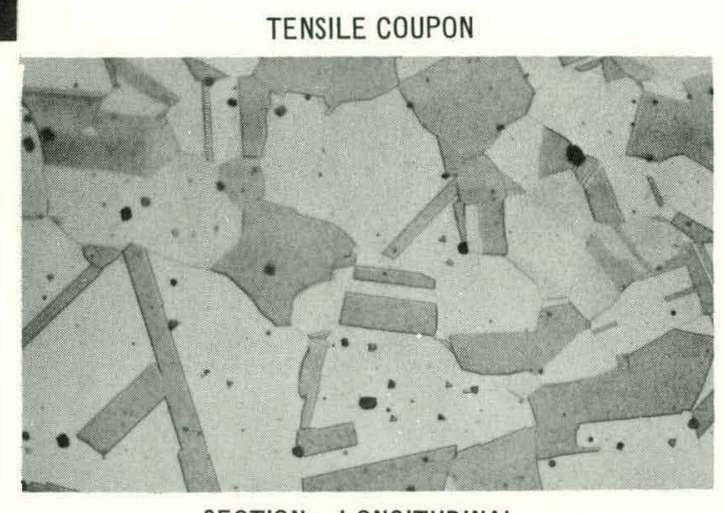

SECTION: LONGITUDINAL MAGNIFICATION: $500 \mathrm{X}$

Figure 4-5. Microstructure of Type-316L Stainless Steel, Mill Annealed. Etchant: $\mathrm{HCl}+\mathrm{H}_{2} \mathrm{O}_{2}$ (Reduced to $\sim 75 \%$ for reproduction purposes) 
TUBULAR COUPON

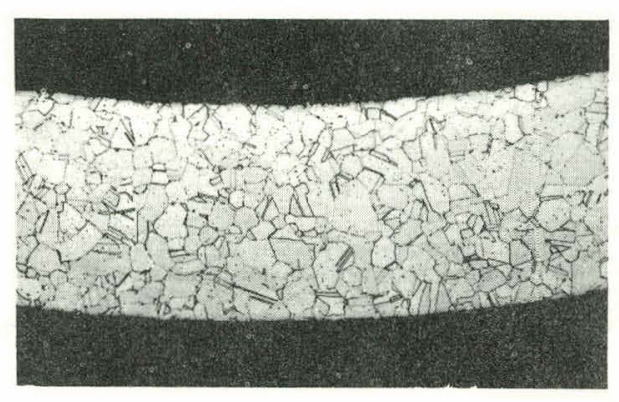

SECTION: TRANSVERSE MAGNIFICATION: $100 \mathrm{X}$

ATSM GRAIN SIZE NO. 6

TENSILE COUPON

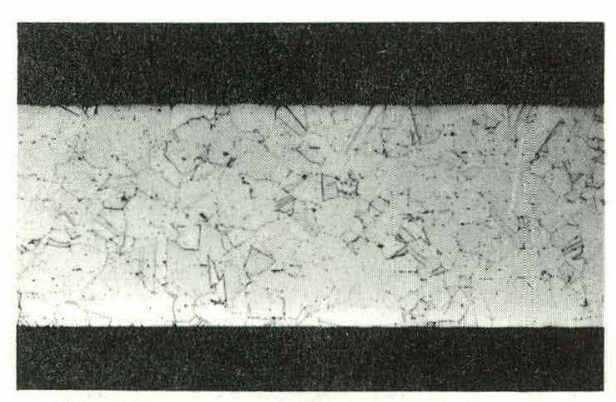

SECTION: LONGITUDINAL MAGNIFICATION: $\quad 100 \mathrm{X}$

ATSM GRAIN SIZE NO. 6
TUBULAR COUPON

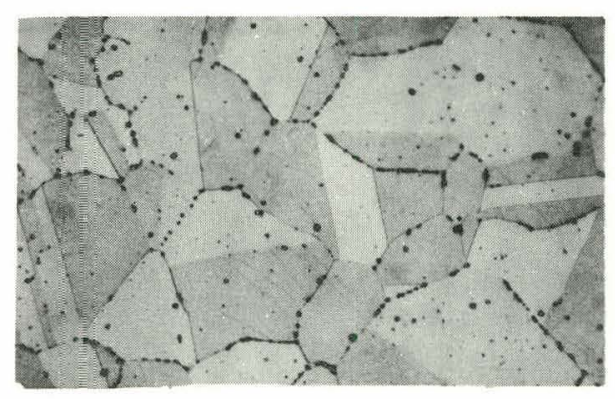

SECTION: TRANSVERSE

MAGNIFICATION: $500 \mathrm{X}$

TENSILE COUPON

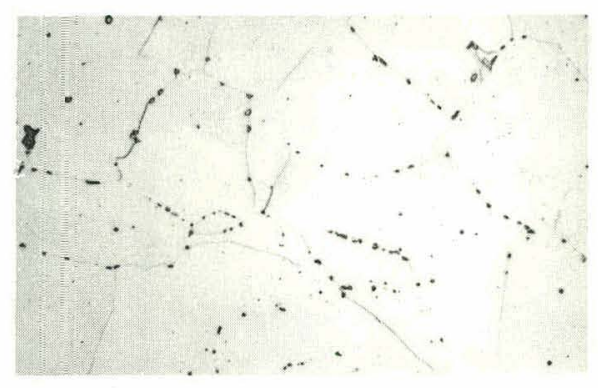

SECTION: LONGITUDINAL MAGNIFICATION: 
TUBULAR COUPON

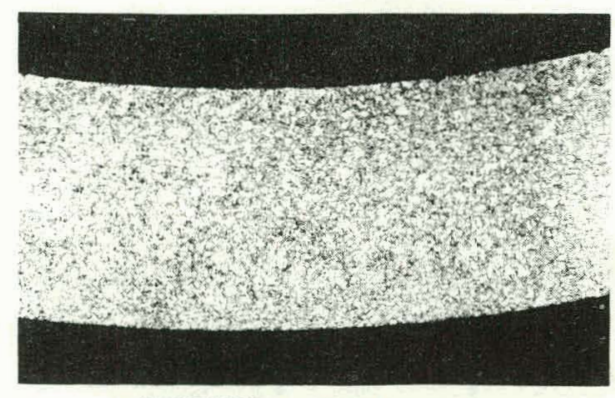

SECTION: TRANSVERSE MAGNIFICATION: $100 \mathrm{X}$

ATSM GRAIN SIZE NO。10
TENSILE COUPON

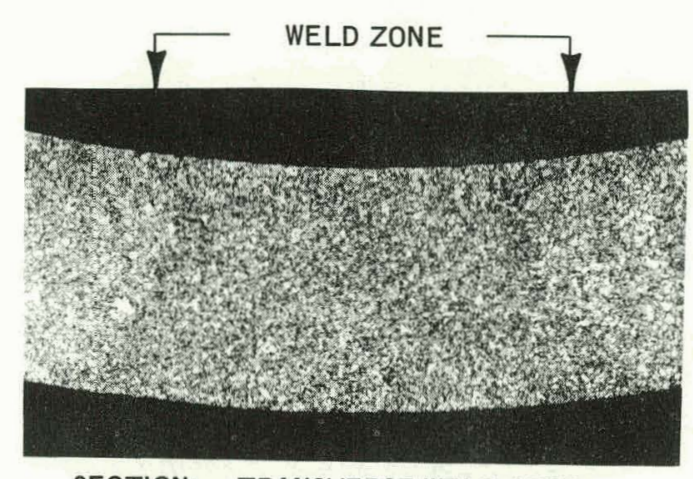

SECTION: TRANSVERSE-WELD AREA MAGNIFICATION:

$$
100 \mathrm{X}
$$

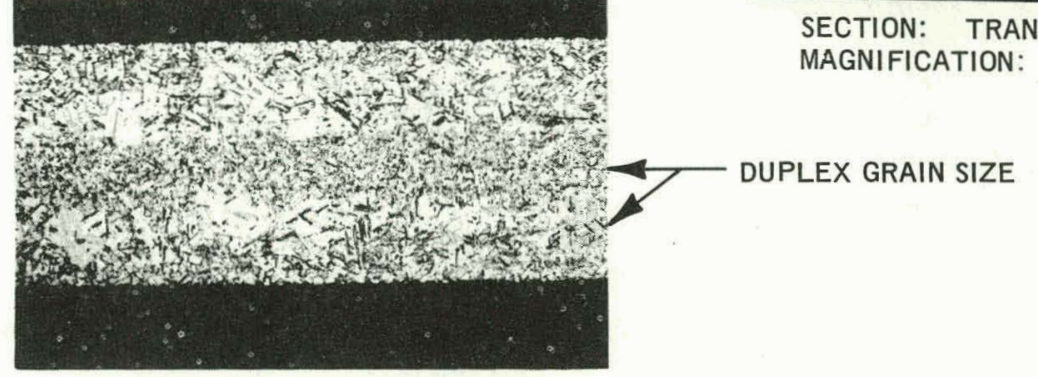

SECTION: LONGITUDINAL MAGNIFICATION:

$100 \mathrm{X}$

TENSILE COUPON

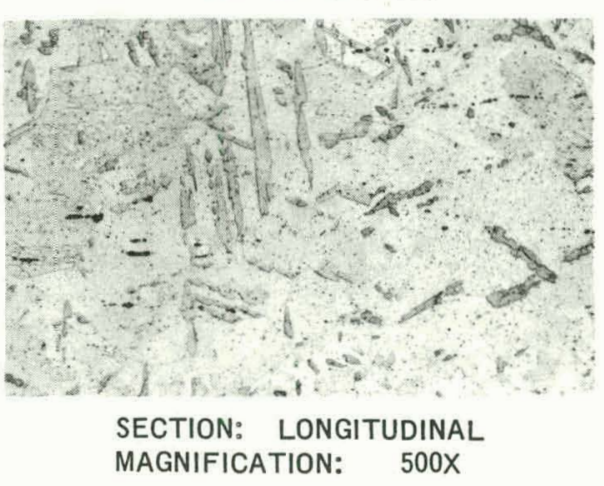

Figure 4-7. Microstructure of Type-321 Stainless Steel, Mill Annealed. Etchant: $\mathrm{HCl}+\mathrm{H}_{2} \mathrm{O}_{2}$ (Reduced to $\sim 75 \%$ for reproduction purposes) 
TUBULAR COUPON

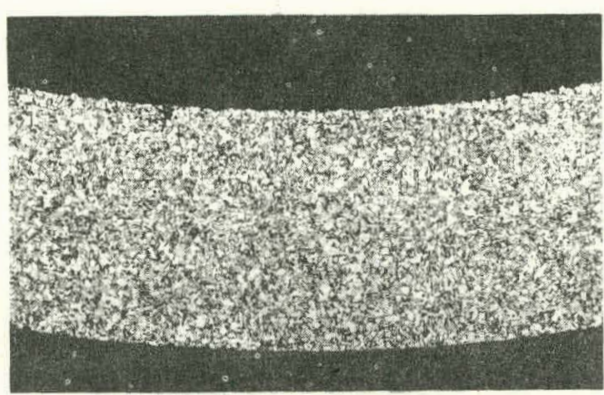

SECTION: TRANSVERSE MAGNIFICATION: $100 x$

ATSM GRAIN SIZE NO. 10

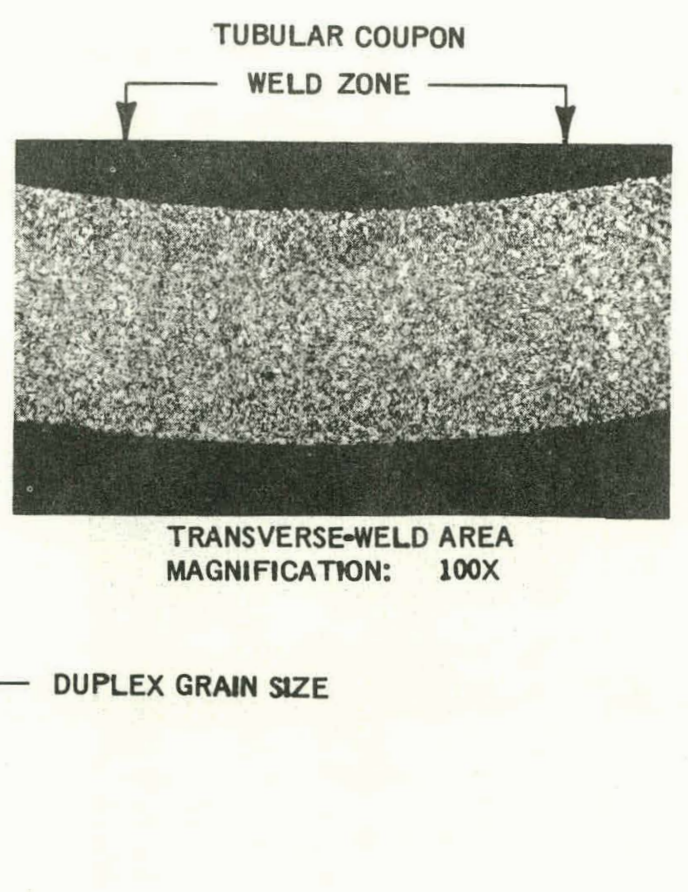

SECTION: LONGITUDINAL

MAGNIFICATION: $100 \mathrm{X}$
TUBULAR COUPON

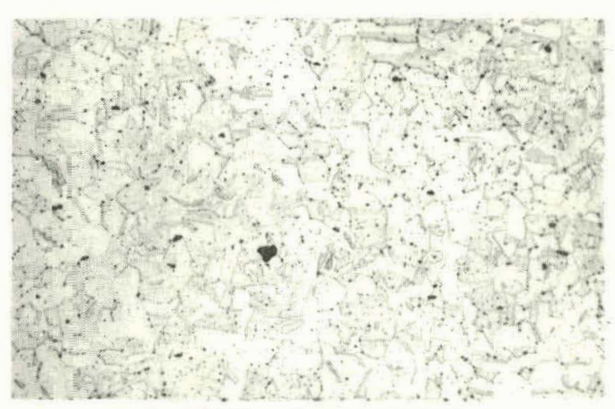

SECTNON: TRANSVERSE

MAGMFICATION: $500 \mathrm{X}$

TENSILE COUPON

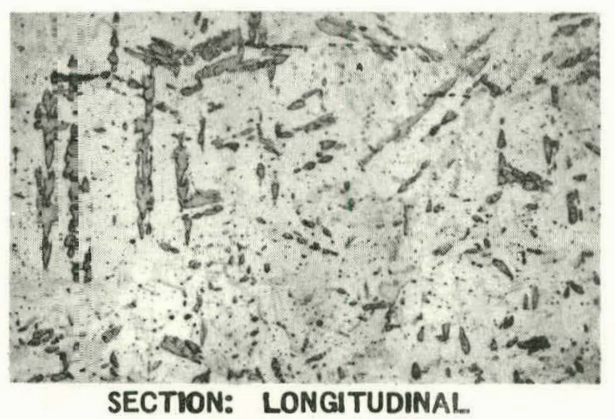

N: LONGITUDINAL

Figure 4-8. Microstructure of Type-321 Stainless Steel, Carbide Agglomerated. Etchant: Modifiti Glyceregia (Reduced to $\sim 75 \%$ for reproduction purposes) 
TUBULAR COUPON

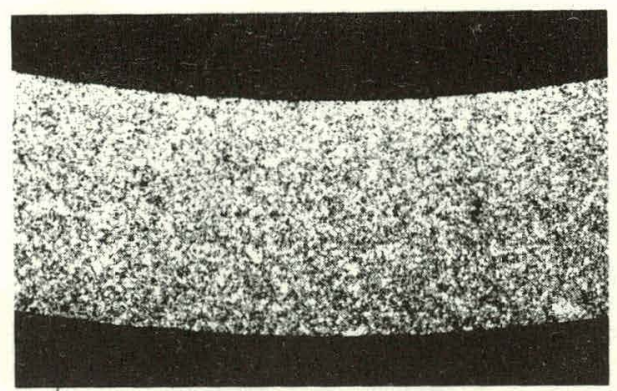

SECTION: TRANSVERSE MAGNIFICATION: 100X

ATSM GRAIN SIZE NO. 10

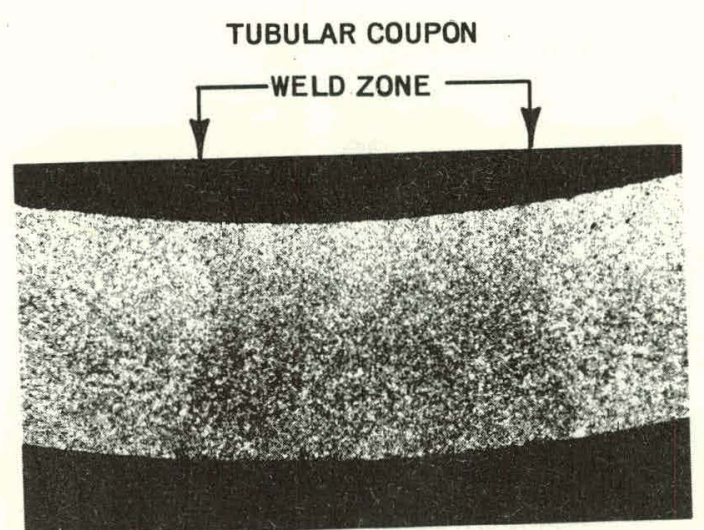

SECTION: TRANSVERSE - WELD AREA MAGNIFICATION: IOOX

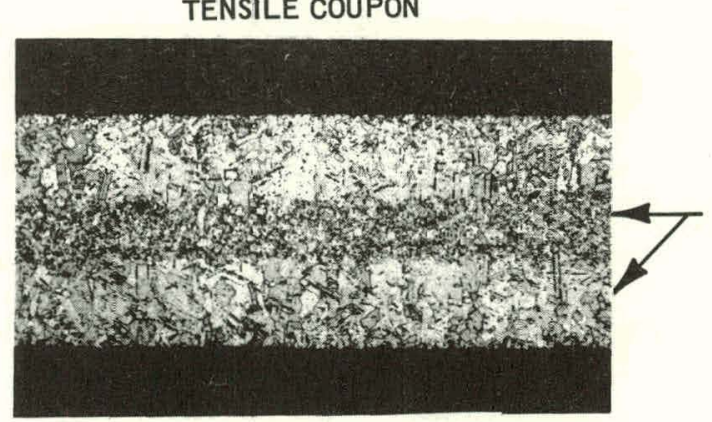

SECTION: LONGITUDINAL MAGNIFICATION:
TUBULAR COUPON

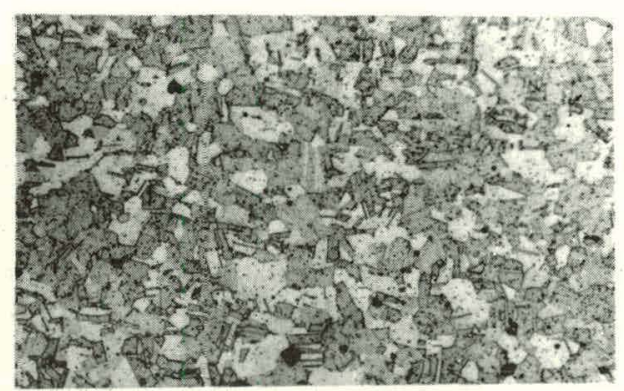

SECTION: TRANSVERSE

MAGNIFICATION: $500 \mathrm{X}$

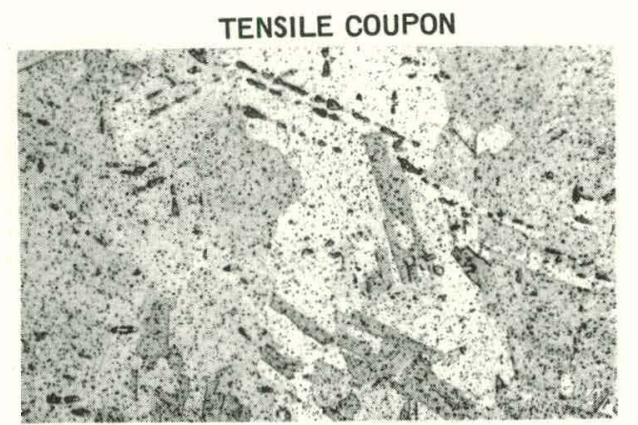

SECTION: LONGITUDINAL MAGNIFICATION:

Figure 4-9. Microstructure of Type-347 Stainless Steel, Mill Annealed. Etchant: $\mathrm{HCl}+\mathrm{H}_{2} \mathrm{O}_{2}$ (Reduced to $\sim 75 \%$ for reproduction purposes) 
TUBULAR COUPON

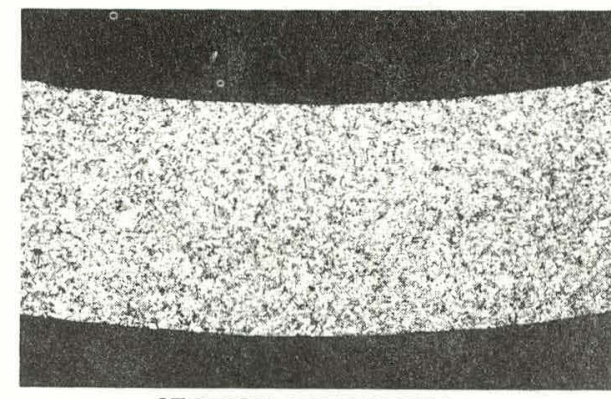

SECTION: TRANSVERSE MAGNIFICATION: $100 \mathrm{X}$

ATSM GRAIN SIZE NO. 10

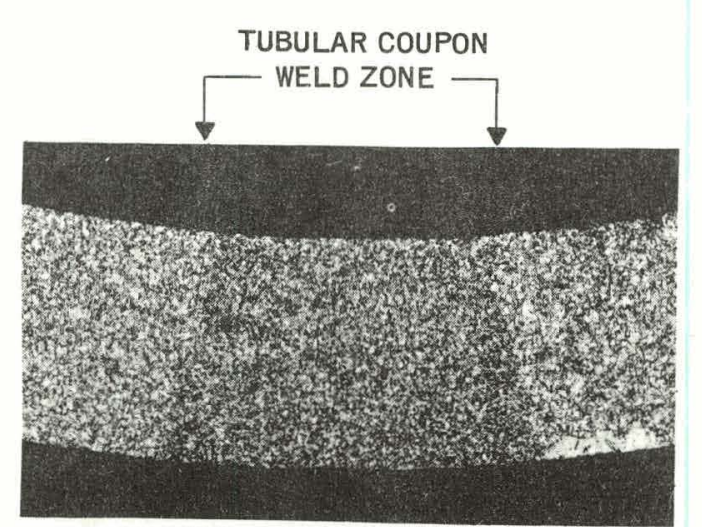

SECTION: TRANSVERSE -WELD AREA MAGNIFICATION: $100 \mathrm{X}$

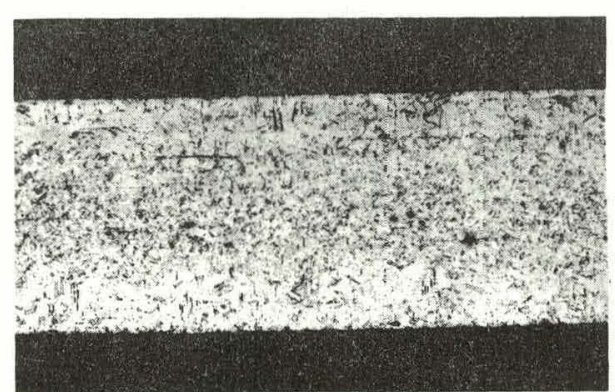

SECTION: LONGITUDINAL

MAGNIFICATION: $100 \mathrm{X}$
TUBULAR COUPON

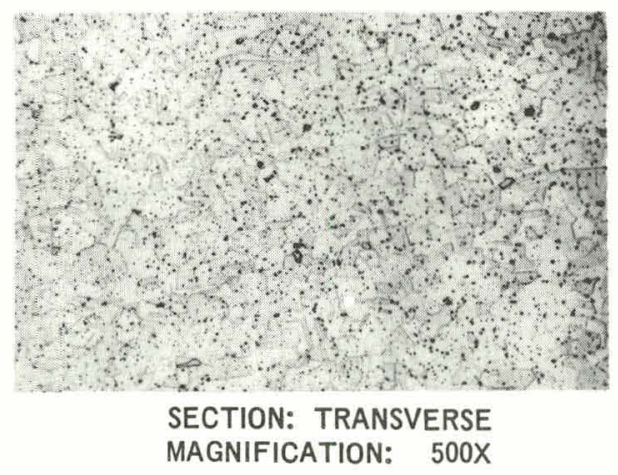

紫

TENSILE COUPON

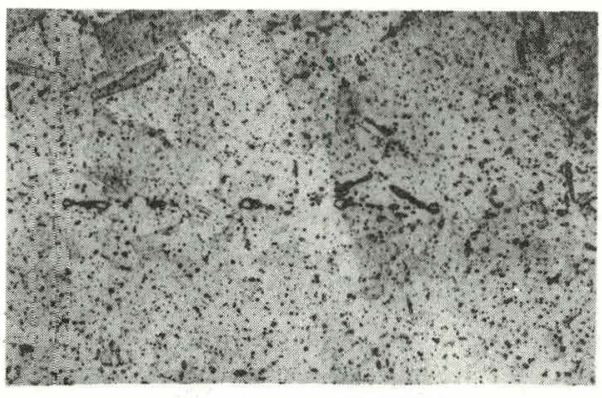

SECTION: LONGITUDINAL

MAGNIFICATION: $500 \mathrm{X}$

Figure 4-10. Microstructure of Type-347 Stainless Steel, Carbide Agglomerated. Etchant: Modified Glyceregia (Reduced to $\sim 75 \%$ for reproduction purposes) 
TUBULAR COUPON

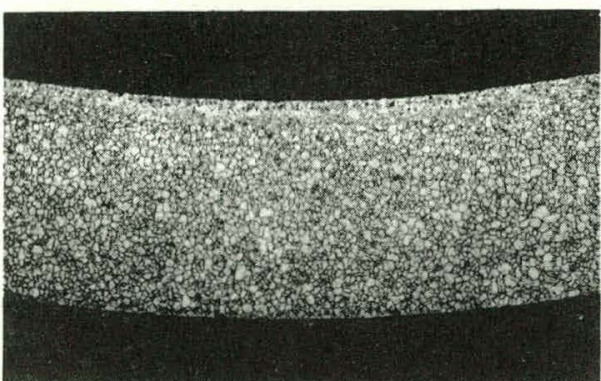

SECTION: TRANSVERSE MANGIFICATION: $100 \mathrm{X}$

ATSM GRAIN SIZE NO: 10

TENSILE COUPON

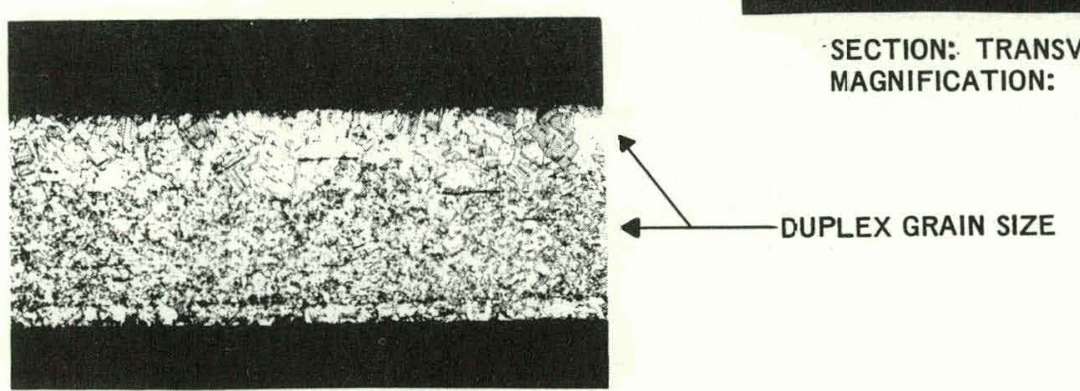

SECTION: LONGITUDINAL MAGNIFICATION: $100 \mathrm{X}$
TUBULAR COUPON

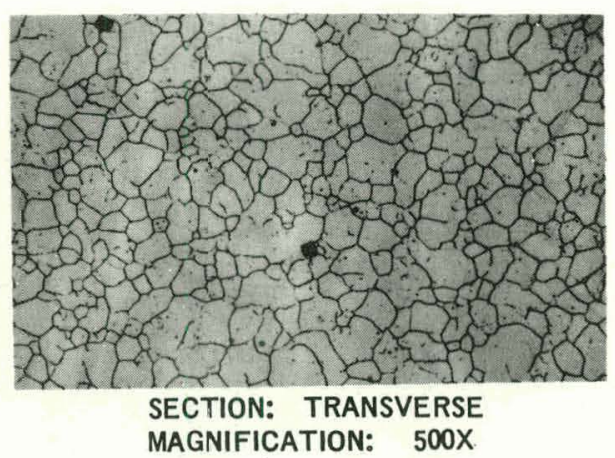

MAGNIFICATION: $500 \mathrm{X}$

TENSILE COUPON

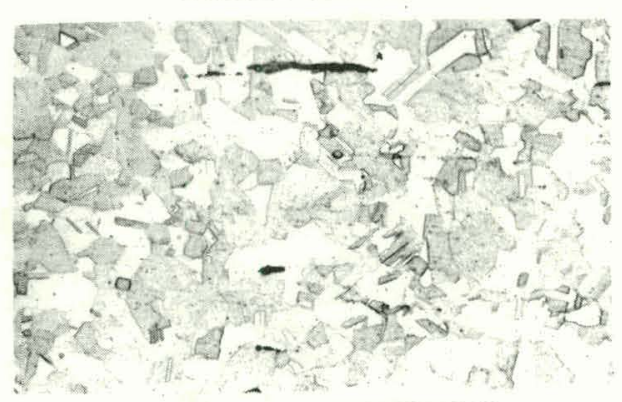

SECTION: LONGITUDINAL MAGNIFICATION: $500 \mathrm{X}$ 
TUBULAR COUPON

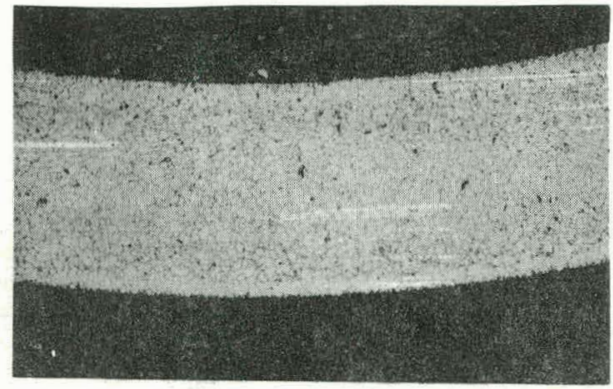

SECTION: TRANSVERSE

MAGNIFICATION: $100 X$

ATSM GRAIN SIZE NO.9
NOTE: WELD WAS FULLY RECRYSTALLIZED: THUS, NO SEAM-WELD COULD BE LOCATED.

TENSILE COUPON

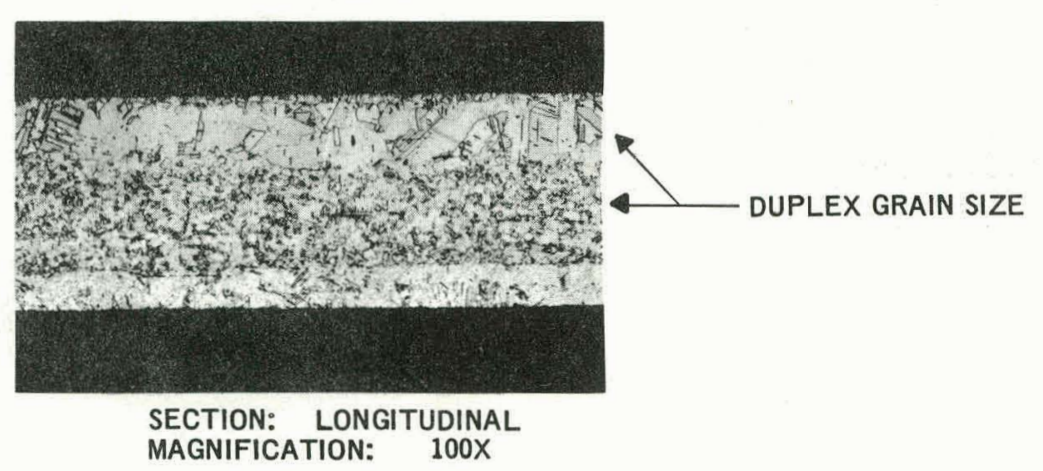

TUBULAR COUPON

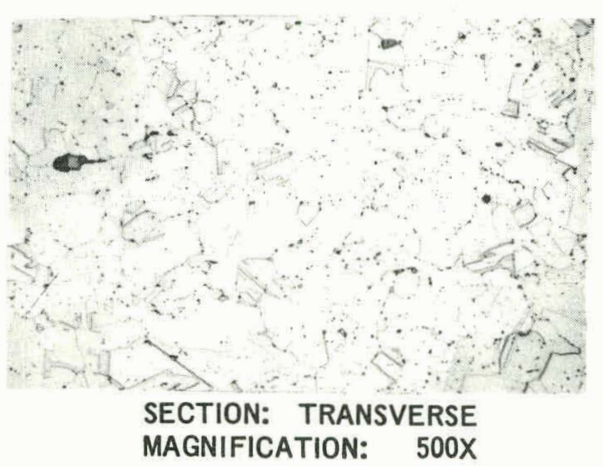

1
10
8
8
8

Figure 4-12. Microstructure of Incoloy-800, Carbide Agglomerated. Etchant: 10\% Oxalic Acid (Reduced to 75\% for reproduction purposes)

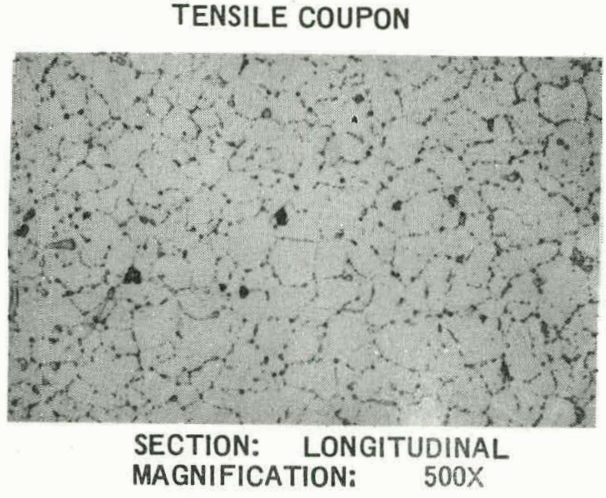


structure is apparent in the tensile coupon section. This structure also appears in tensile coupons of Types 321 (Figure 4-7 and 4-8), 347 (Figures 4-9 and 4-10), and Incoloy-800 (Figures 4-11 and 4-12). Consistently large grains are at the outer surfaces, with a fine-grain structure near the centroid. The outer and inner fibers are regions of maximum strain (during the flattening and stamping operation), and the middle region is one of minimum deformation. It is possible, therefore, that the $1800^{\circ} \mathrm{F}$ anneal caused recrystallization and grain growth to occur at the regions of maximum strain. The center region was unaffected because of the lack of appreciable cold work.

The carbide-agglomerated Type 316 is shown in Figure 4-6. The structure is similar to mill-annealed Type $316 \mathrm{~L}$, except that carbide precipitation is now evident at grain boundaries in discrete locations-somewhat comparable to the carbide-agglomerated Type 304.

A very fine grain size (ASTM 10) was observed in both structural conditions of Type 321 (Figures 4-7 and 4-8), and the weld region was fully recrystallized. Type 347 , in both the mill-annealed (Figure 4,-9) and carbideagglomerated (Figure 4-10) structures, was nearly identical in grain size to Type 321. The weld area in Type 347, however, was not fully recrystallized. Types 321 and 347 did not respond to the carbide-agglomeration heattreatment to the extent shown by Types 304 and 316 . In these specimens, stabilized carbides were uniformly distributed throughout the structure.

Mill-annealed Incoloy-800 (Figure 4-11) has a grain size of ASTM 10, and the carbide-agglomerated structure (Figure 4-12) is about ASTM 9. The weld region was not easily observed in the mill-annealed material and could not be located in the material which was heat-treated for agglomeration of carbides. That this heat treatment was partially successful in forming discrete intergranular carbides is illustrated in Figure 4-12, but continuous grainboundary precipitates are also in evidence.

\subsection{IRRADIATION CAPSULE}

The capsule configuration used in all three subassemblies consisted of several tubular test sections axially strung together in a "piggy-back" fashion. Series L-2' (Figures 4-13 through 4-15) contained three test sections per capsule; series I -4 and L-4' each had five (Figures 4-16 through 4-18). The test section consisted of a 0.250 -inch-o.d. by 0.220 -inch-i.d. tube which encased several tensile coupons, a tungsten holder for gamma heating, a thermometer capsule containing fusible metal rods to provide indications of temperature of irradiation, and sodium to promote axial and radial heat transfer from the tungsten to the tubular test section.

By balaneing the heat generated by gamma heating of all metal components in the capsule with the heat loss across an argon-filled annulus, the capsule was designed to operate at $1200^{\circ} \mathrm{F}$. Since no external instrumentation was possible on these capsules, approximate indications of temperatures attained were provided by fusible metal thermometry. This technique is based on the judicious selection of metals or alloys with well-established melting points in the temperature range of interest. Meltdown of the alloys is then observed by radiography or, when recovery of the thermometer is possible, by direct observation.

Internal pressure at temperature was provided as follows: The assembled test sections and sodium reservoir were flushed with helium prior to sodium filling, to purge the system of air. Liquid sodium was then allowed to fill the test sections from the capsule bottom to a set level in the sodium reservoir, and then solidified. The level of solid sodium in the reservoir was then measured with an eddycurrent probe. The test coupon assembly was then filled with helium gas to a preselected pressure level associated with the measured sodium level. This initial pressure is designed to increase to a higher pressure level during reactor operation due to the temperature increase and volume decrease of the gas (caused by the expanding sodium). This higher pressure level was selected to produce a hoop stress in the tubular test section of approximately $80 \%$ of the reported 10,000 -hour stress-rupture value at $1200^{\circ} \mathrm{F}$. These target stress levels are listed in Table 4-2.

\subsection{HISTORY OF IRRADIATION}

\subsubsection{EBR-II History}

Capsule series $1,-2^{\prime}$ was loaded into EBR-II (S/A X(,06) on September 3, 1965, and removed on February 20, 1967. During its residence in the reactor (Runs 9 through 24), the subassembly occupied position 4E2 (Row 4) and accumulated 9317 megawatt days (MWD). This corresponds to a fluence (based on reactor physics calculations) $^{*}$ of $3.4 \times 10^{22} \mathrm{n} / \mathrm{cm}^{2}$, total, at the core midplane-approximately 207 effective full-power days (EFPD).

Series L-4 (S/A X009) was inserted into the core at the beginning of Run 15 (March 24, 1966), and was removed at the completion of Run 22 (November 14, 1966). The subassembly occupied position 4A2 (Row 4) for 119 EFPD and reached an exposure of 5355 MWD or $1.9 \times$ $10^{22} \mathrm{n} / \mathrm{cm}^{2}$, total.

A Row-2 core position (2D1) was used to irradiate series L-4' (S/A X014). Loaded on July 17, 1966, and removed on April 10, 1967, the L-4' capsules were exposed in the reactor for Runs 20 to 24 . The total neutron fluence was $1.7 \times 10^{22} \mathrm{n} / \mathrm{cm}^{2}$ (3674 MWD) at 82 EFPD.

* The accumulated exposure based on reactor physics calculations is reported on a quarterly basis in the EBR-II Operations Report: also is mentioned in Reference 6 of this report. 
The EBR-II grid loading pattern for these three experiments is shown in Figure 4-19. The location of each of the capsules within each subassembly is presented in Figures 4-20, 4-21, and 4-22 for series L-2', L-4, and L-4', respectively.

\subsubsection{Dosimetry}

Fast-neutron damage to austenitic stainless steels at elevated temperatures is thought to be associated with the production of helium gas and cavities (Ref. 1-4). Although mechanisms regarding the formation of cavities are still subject to question, it is generally agreed that they are the result of a combination of two discrete phenomena: gas producing neutronic reactions $[(n, \alpha)$ reactions $]$ with alloy constituents, and vacancy-producing displacement collisıons.

Lattice displacements begin to occur at neutron energies around $10 \mathrm{keV}$ (Ref. 5), and helium production is believed to have a threshold reaction at about $6 \mathrm{MeV}$. Thus, knowledge of the total flux, as well as the high-energy region of the neutron spectrum in an experimental fast reactor, is necessary in order to assess the degree of fastneutron damage in austenitic stainless steels.

Materials irradiation experiments in the EBR-II have used flux wires as a means for determining the flux spectra during reactor exposure. In this experiment, the integrated fast-neutron exposure was monitored by the reaction $\mathrm{Fe}^{54}$ $(\mathrm{n}, \mathrm{p}) \mathrm{Mn}^{54}$, which has a half-life of 303 days, and $\mathrm{Ni}^{58}$ $(n, p) \operatorname{Co}^{58}$ with a half-life of 71 days. The dosimetry results from the three-capsule series were reported previously (Ref. 6) and are summarized in Figure 4-23. Subassemblies XG06 (L-2'), X009 (L-4) and X014 (1-4') were irradiated to fast fluences $(\mathrm{En}>1 \mathrm{MeV})$ of $6.7 \times 10^{21}, 3.9$ $\times 10^{21}$, and $3.0 \times 10^{21}, \mathrm{n} / \mathrm{cm}^{2}$, respectively, as determined by flux wire analysis.*

\subsubsection{Evaluation of Temperature During Exposure}

As discussed in subsection 4.2 , each materials test section contained a temperature monitor consisting of fusible metal alloys (sentinels) which have well established melting points in the temperature range of interest. The configurations of the two types of monitors used are illustrated in Figures 4-15 and 4-18.

All $\mathrm{l}_{-}-2^{\prime}$ pins contained three monitors, equally spaced along the pin (approximately $51 / 2$ inches apart) as shown in Figure 4-13. Each monitor contained three sentinels capped with stainless steel dises. In both the upper and middle

This method for determining neutron fluence in EBR-II yields total fluence values for row 2 and row 4 locations that are $60 \%$ and $40 \%$ lower, respectively, than those values based on the power normalization method used by ANL. ${ }^{6}$ monitor (test sections 1 and 2) the sentincls consisted of the following materials:

$$
\begin{aligned}
& \text { Pure aluminum }\left(\mathrm{MP}=1220^{\circ} \mathrm{F}\right) \\
& \mathrm{Al}-11.7 \mathrm{Si}\left(\mathrm{MP}=1070^{\circ} \mathrm{F}\right) \\
& \mathrm{Al}-33 \mathrm{Cu}\left(\mathrm{MP}=1018^{\circ} \mathrm{F}\right)
\end{aligned}
$$

Of the five pins discussed here, four contained a monitor in the lower test section in which the Al-Si sensor was replaced by the low-temperature eutectic Ag-4.5Sb (MP = $\left.903^{\circ} \mathrm{F}\right)$.

All L4 and L4' pins contained five monitors, spaced approximately 3-1/2 inches along the pin (Figure 4-16). Each monitor contained three sentinels capped with stainless steel spherical balls. The sentinels consisted of the same materials as were used in test sections 1 and 2 of the $L 22$ pins.

The detailed evaluation of each alloy sentinel (or indicator disc) used in the $L 2^{\prime}, L-4$, and $L 4^{\prime}$ series of materials capsules is listed in Table 4-3. Also shown are the maximum temperatures attained in each test section. A typical temperature distribution curve (from the data of $\mathrm{LAB}$ ) is shown in Figure 4-24.

The uncertainties associated with this technique are related primarily to uncertainty in the axial heat transfer from test section to temperature monitors, and the lack of adequate sensitivity during the post-irradiation measurement. Several kinds of events are suspected that can invalidate occasional measurements. Indicator hangup or melting of the fusible alloy during fabrication welding are two possibilities.

To confirm the nondestructive readout of temperature monitors, post-irradiation metallography was also conducted on selected sentinels. The results showed that all sensors positioned in the core region had undergone melting, indicating that a temperature greater than $1200^{\circ} \mathrm{F}$ was attained. Monitors in the upper blanket region (test section No. 1 for the $\mathrm{L}_{2}$ ' series), on the other hand, showed that only the $\mathrm{Al}-33 \mathrm{Cu}$ sentinel melted, indicating that a temperature greater than $1018^{\circ} \mathrm{F}\left(548^{\circ} \mathrm{C}\right)$ but less than $1070^{\circ} \mathrm{F}^{\prime}\left(577^{\circ} \mathrm{C}\right)$ was reached in this position. A schematic of a representative monitor, a neutron radiograph and metallographic cross sections of the monitors used in test sections L.4F-4 and L20-2 are shown in Figures 4-25 and 4-26.

Although the fusible metal thermometers used in these test capsules provided valuable information on the temperature of irradiation, the uncertainties mentioned above emphasize the need for direct monitoring of temperature-a need that can be satisfied only by using externally instrumented capsules. 


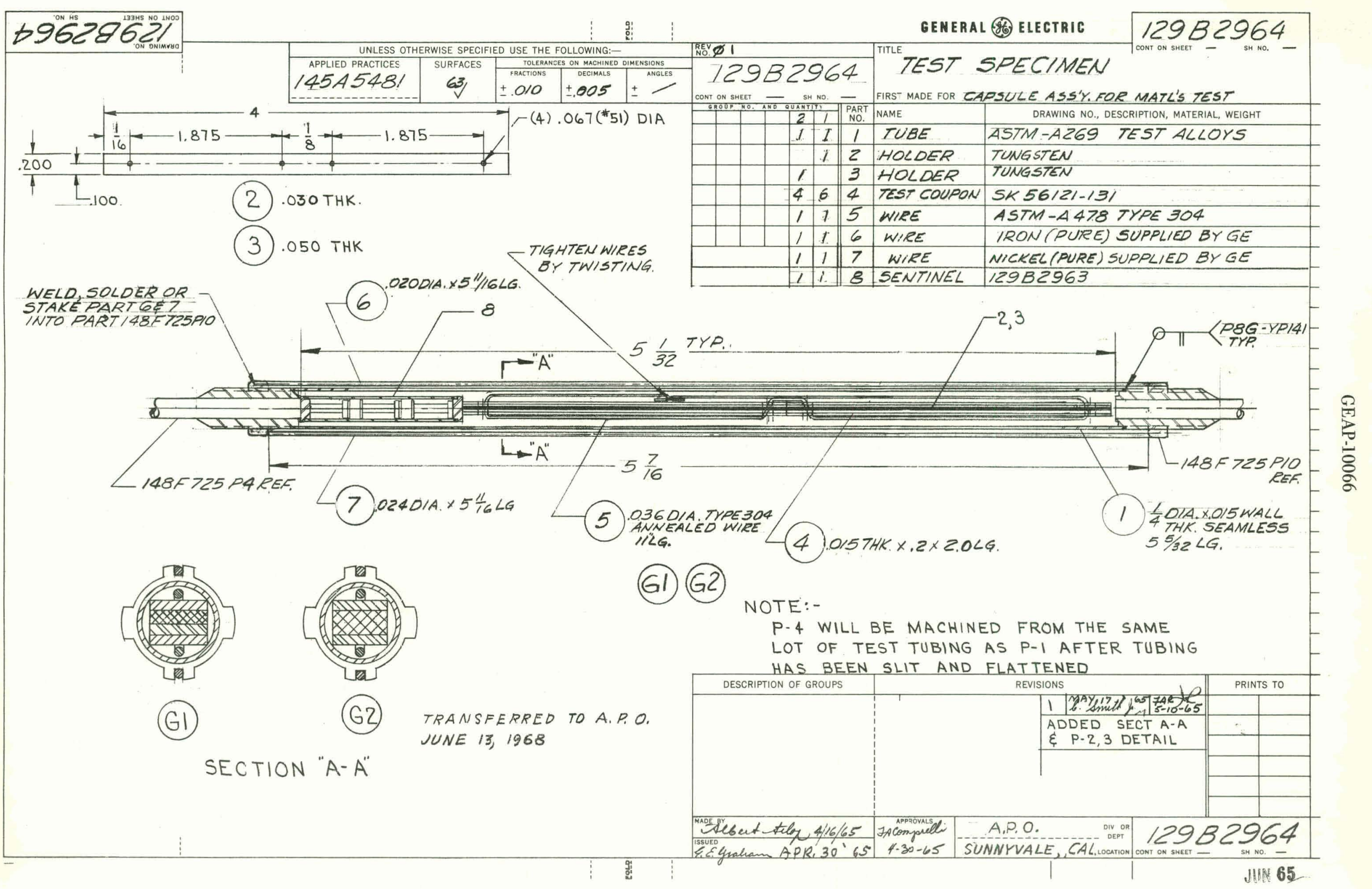

Figure 4-14. Series L-2' Irradiation Capsule: Test Specimen 


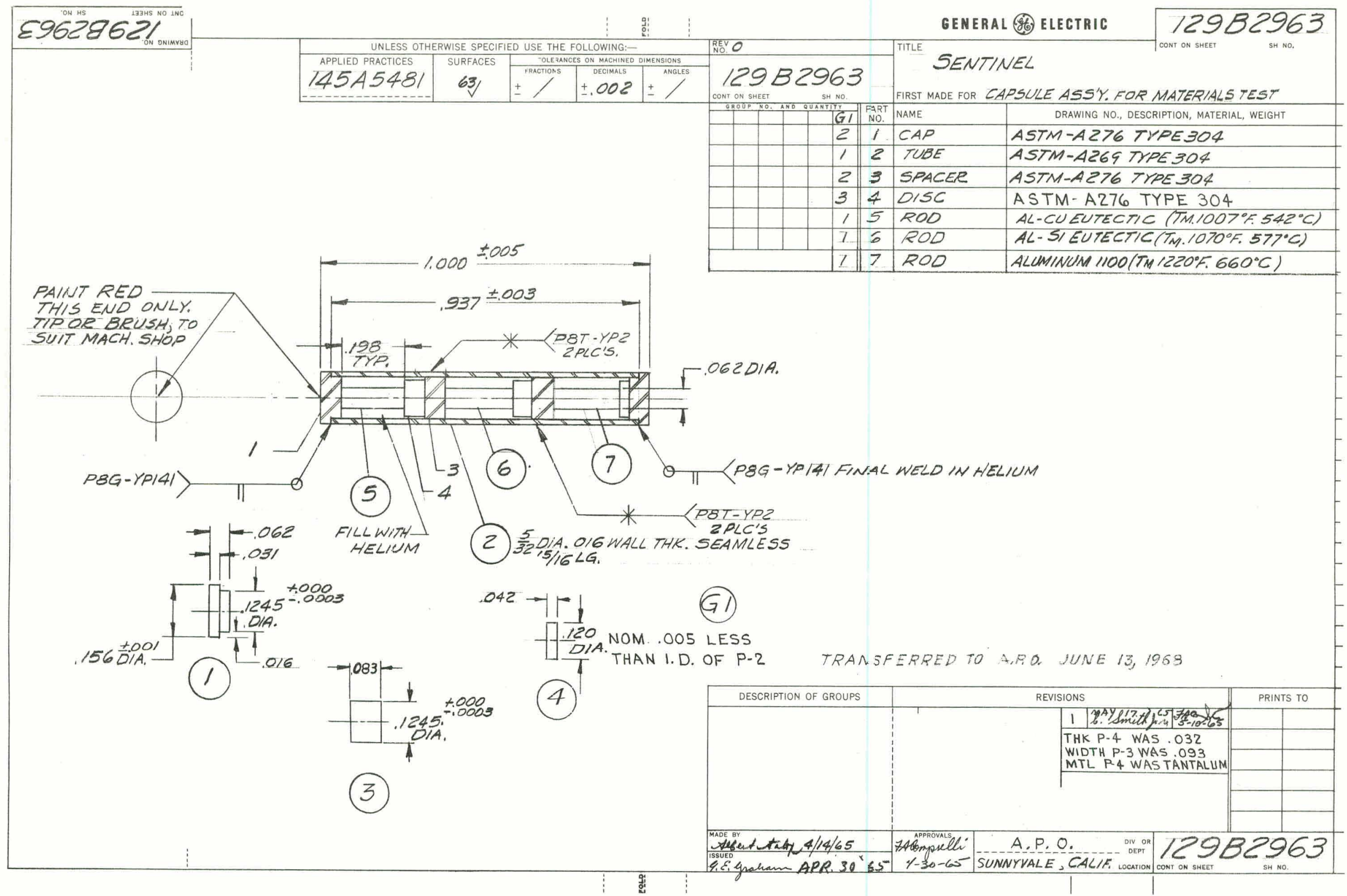




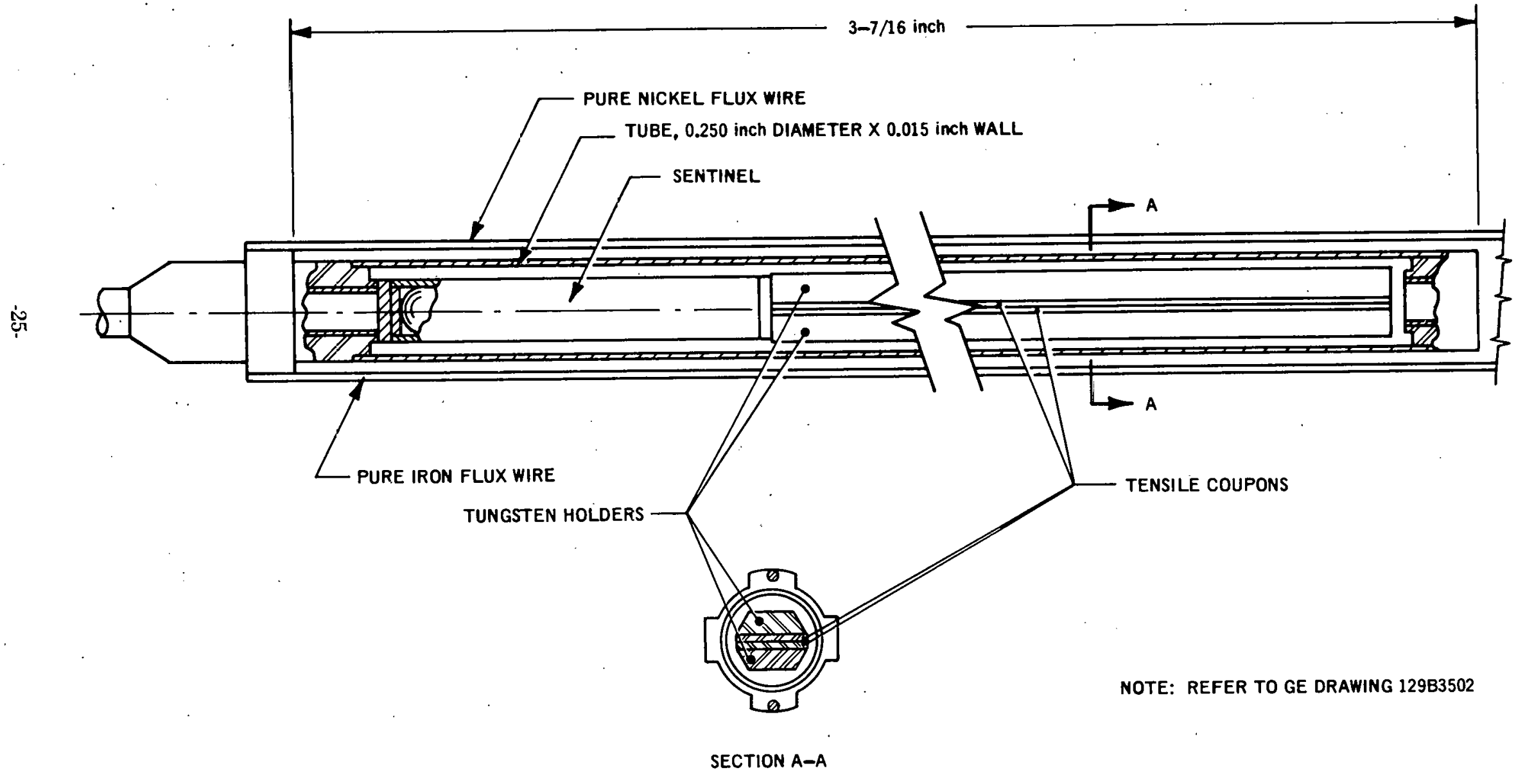




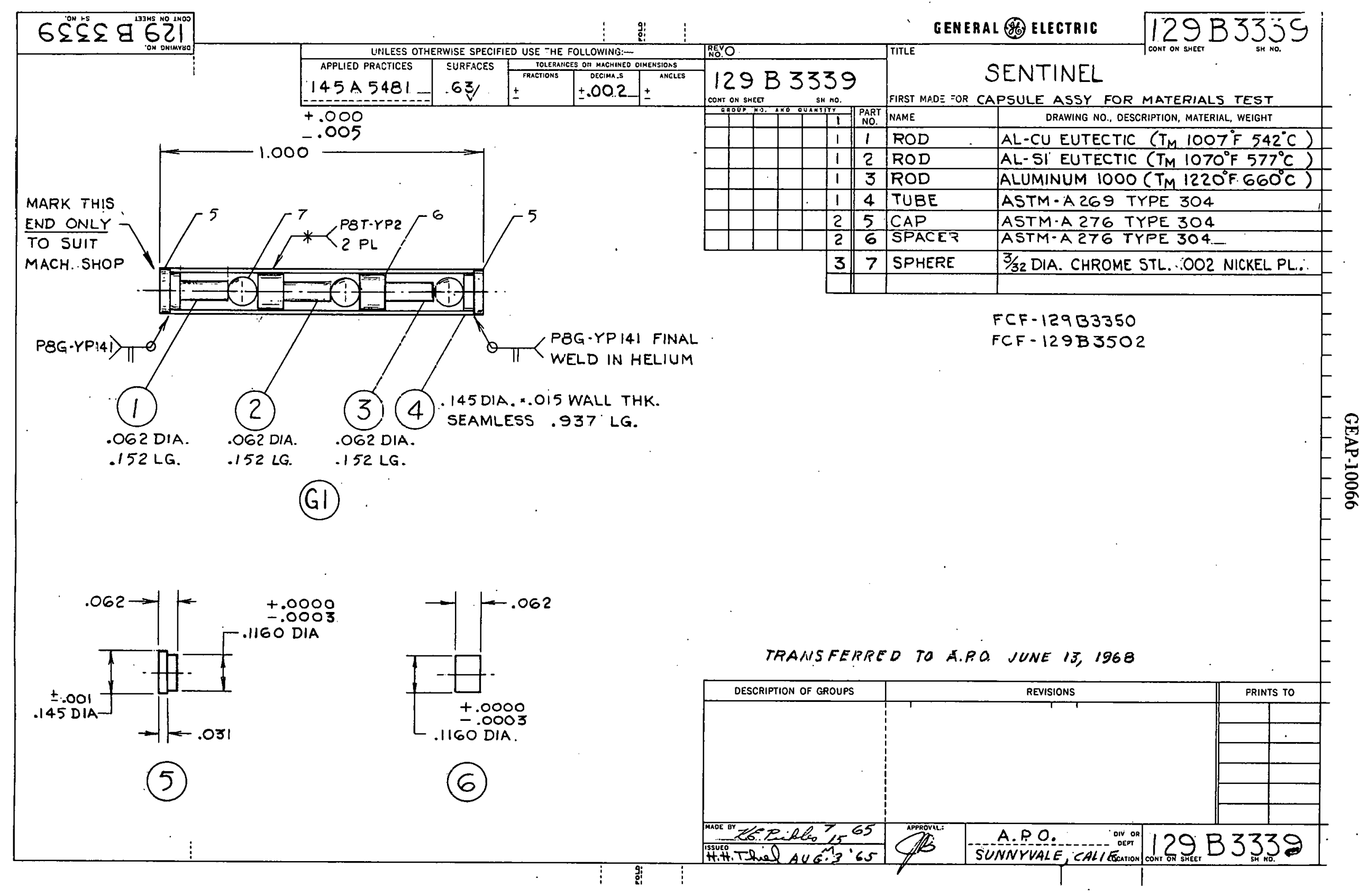

Figure 4-18. Series L-4/L-4' Irradiation Capsule: Sentinel 


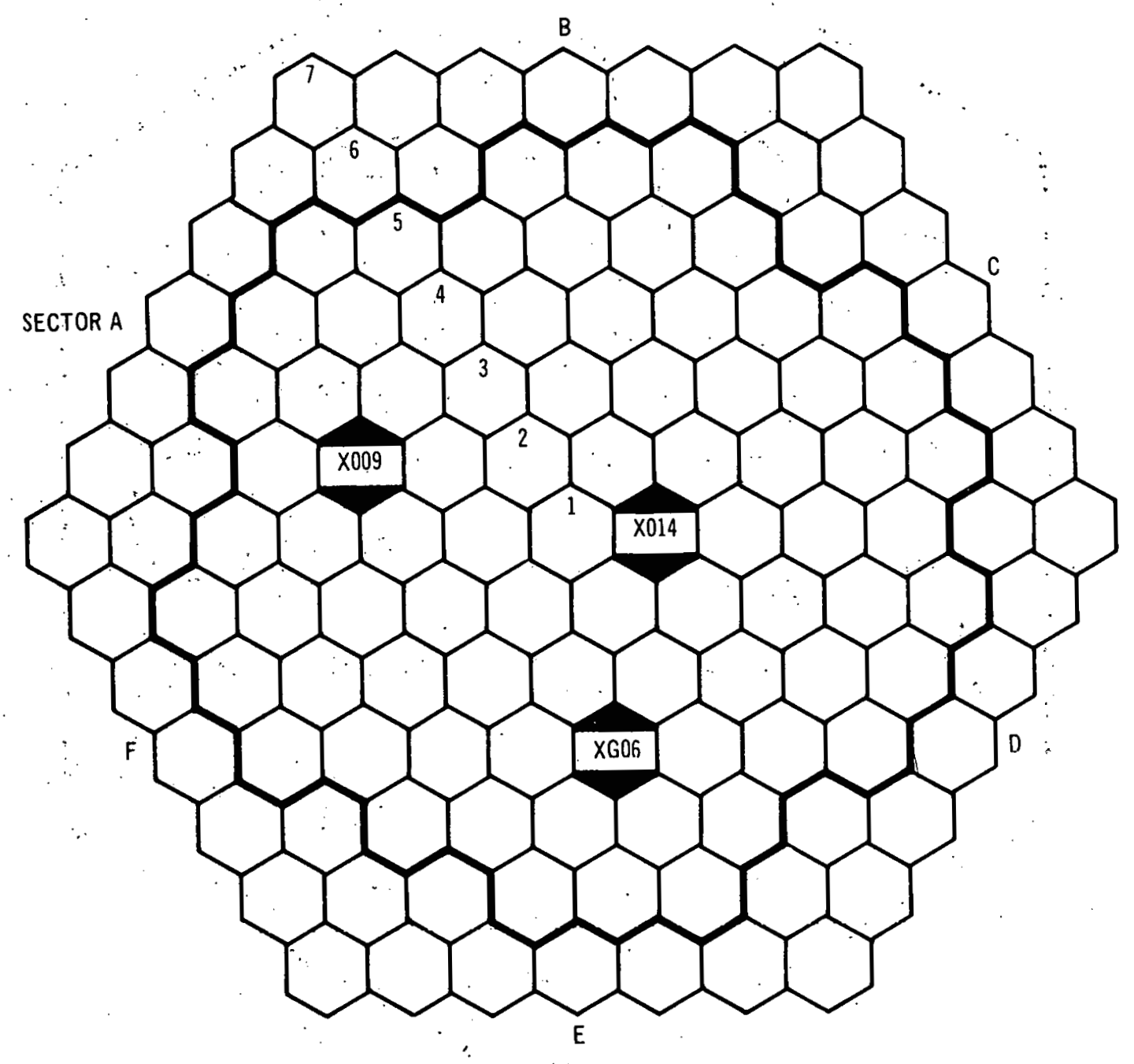

Figure 4-19. EBR-II Loading Pattern 


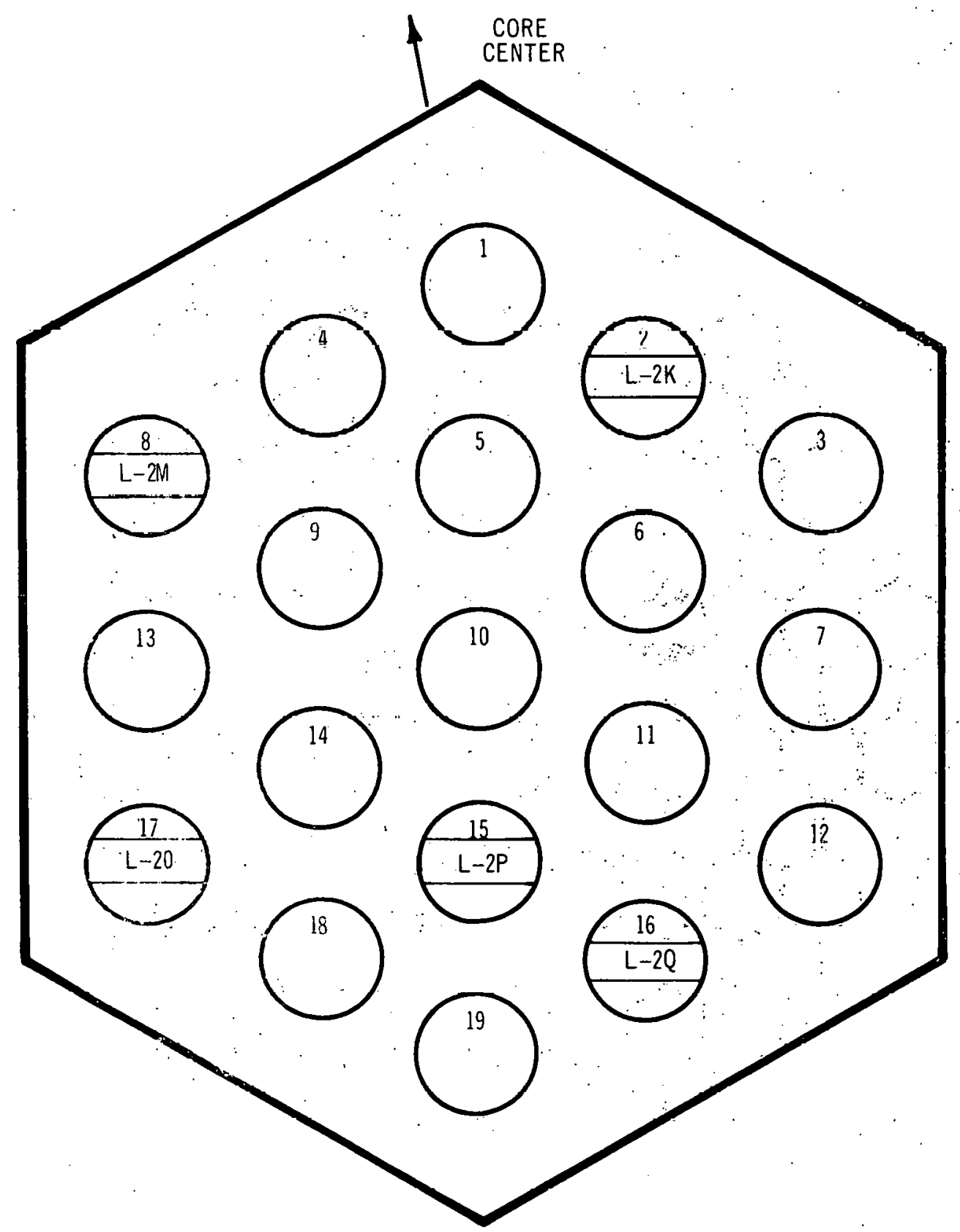

SUBASSEMBLY NO. XGO6

CORE LOCATION $4 E$ ?

Figur: 1-20. Subassembly Diagram, XG06 
1

GEAP.10066

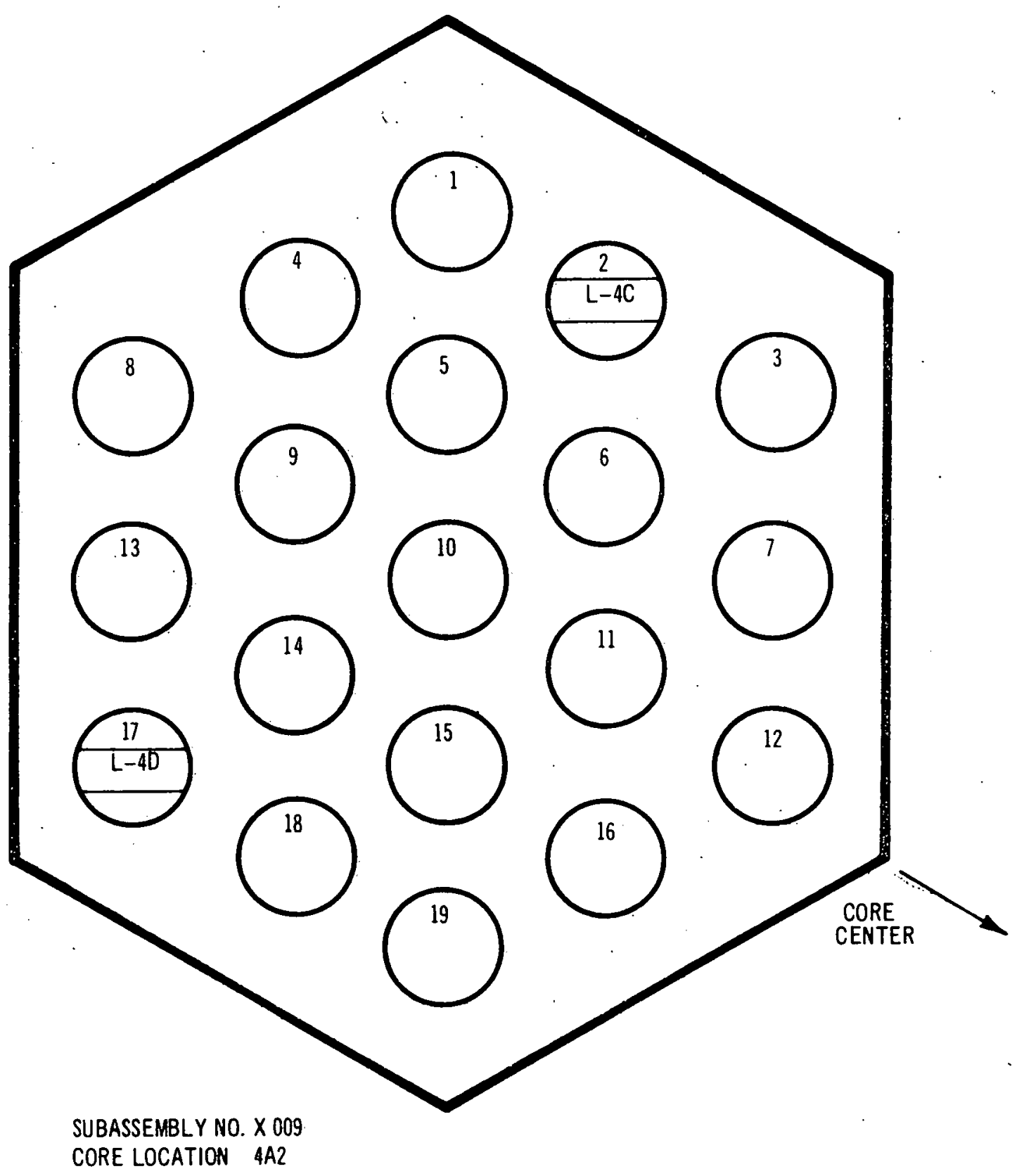

Figure 4-21. Subassembly Diagram, XOO9

$-29$. 


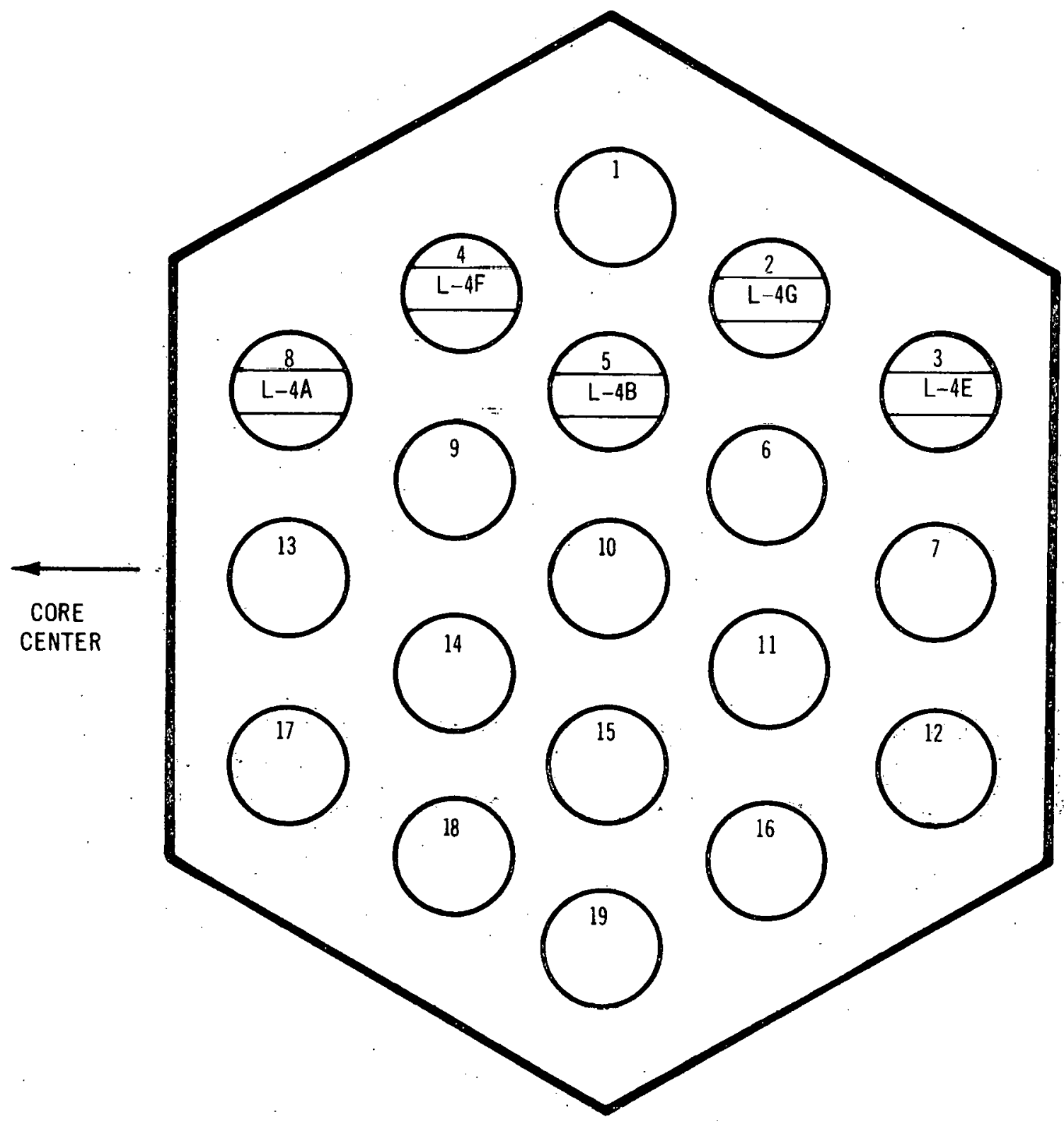

SUBASSEMBLY NO. X014

CORE LOCATION 2D1

Figure 4-22. Subassembly Diagram, XO14 
TABLE 4-3

SUMMARY OF TEMPERATURE MONITOR DATA

\begin{tabular}{|c|c|c|c|}
\hline Pin Number & Region & $\begin{array}{l}\text { Maximum Temperature } \\
\text { Attained }\left({ }^{\circ} \mathbf{F}\right)\end{array}$ & $\begin{array}{l}\text { Pin Maximum } \\
\text { Temperature } \\
\left({ }^{\circ} \mathrm{F}\right)\end{array}$ \\
\hline $\mathrm{l}, 2 \mathrm{~K}$ & $\begin{array}{l}\text { No portion } \\
\text { high as the I } \\
\text { (MP = } 1018\end{array}$ & $\begin{array}{l}\text { ned a temperature as } \\
\text { ing sentinel, } \mathrm{Al}-33 \mathrm{Cu}\end{array}$ & $<1018$ \\
\hline $\mathrm{L} .2 \mathrm{M}$ & $\begin{array}{l}\text { Upper } 1 / 3 \\
\text { Middle } 1 / 3 \\
\text { Lower } 1 / 3\end{array}$ & $\begin{aligned}< & 1018 \\
& 1070>\mathrm{T}>1018 \\
& 1220>\mathrm{T}>1018\end{aligned}$ & $1220>\mathrm{T}>1018$ \\
\hline 1.20 & $\begin{array}{l}\text { Upper } 1 / 3 \\
\text { Middle } 1 / 3 \\
\text { Lower } 1 / 3\end{array}$ & $\begin{array}{l}1070>T>1018 \\
1.070>T>1018 \\
1018>T>903\end{array}$ & $1070>T>1018$ \\
\hline L2P & $\begin{array}{l}\text { Upper } 1 / 3 \\
\text { Middle } 1 / 3 \\
\text { Lower } 1 / 3\end{array}$ & $\begin{aligned} & 1,070>T>1018 \\
& 1070>1>1018 \\
&> 1.220\end{aligned}$ & $>1220$ \\
\hline $1.2 Q$ & $\begin{array}{l}\text { Upper } 1 / 3 \\
\text { Middle } 1 / 3 \\
\text { Lower } 1 / 3\end{array}$ & $\begin{array}{l}1070>T>1018 \\
1.070>\Gamma>1018 \\
1018>\Gamma>903\end{array}$ & $1070>T>1018$ \\
\hline $\mathrm{L} 4 \mathrm{C}$ & $\begin{array}{l}\text { Upper } 1 / 5 \\
\text { Second } 1 . / 5 \\
\text { Middle } 1 / 5 \\
\text { Fourth } 1 / 5 \\
\text { Lower } 1 / 5\end{array}$ & $\begin{aligned}< & 1018 \\
& 1.220>\mathrm{T}>1070 \\
> & 1.220 \\
> & 1018 \\
& 1070>\mathrm{T}>1018\end{aligned}$ & $>1220$ \\
\hline L4D & $\begin{array}{l}\text { Upper } 1 / 5 \\
\text { Second } 1 / 5 \\
\text { Middle } 1 / 5 \\
\text { Fourth } 1 / 5 \\
\text { Lower } 1 / 5\end{array}$ & $\begin{aligned}< & 1018 \\
& 1220>1>1.070 \\
& 1220>\mathrm{T}>1070 \\
& 1.220>\mathrm{T}>1.070 \\
> & 1220\end{aligned}$ & $>1220$ \\
\hline
\end{tabular}

NOTE

Since there is evidence to suggest that the aluminum sentinel had melted on a number of L4 monitors during welding, the apparent indication of melting in the lower $\mathrm{L} 4 \mathrm{D}$ monitor and the middle $\mathrm{L} 4 \mathrm{C}$ monitor should be disregarded. The probable pin temperature should be considered to be 1220>' $>1070$.

Pin Number

L4A
Region

Upper test section

Second test section

Middle test section

Fourth test section

Lower test section

\section{Maximum Temperature} Attained $\left({ }^{\circ} \mathbf{F}\right)$

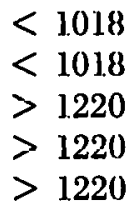


TABLE 4-3 (Continued)

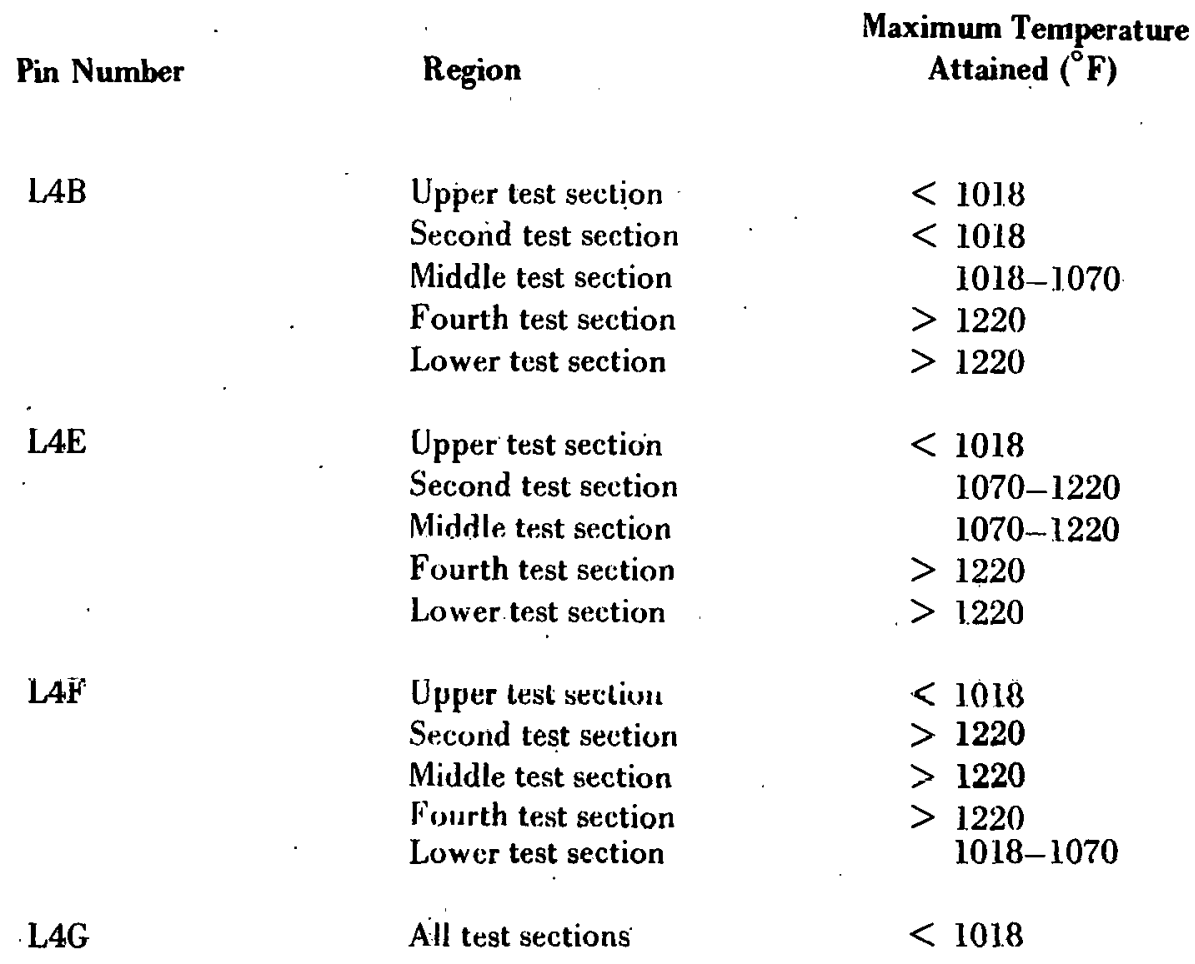

\section{Significant Observations}

a. The maximum temperature attained in all pins except L4G was in excess of $1220^{\circ} \mathrm{F}$.

b. The positions of the lower three monitors bracketed the highest temperature region of the cure pusilion.

c. The maximum temperature attained in $L 4 G$ was below the minimum melting temperature of $1018^{\circ} \mathrm{F}$. d. The temperature of the region occupied by the upper monitor was below the minimum detectable terlperaturc in all pins.

e. The effeclive temperature during irradiation oan be catimatod to $\pm 50^{\circ} \mathrm{F}$ with a reasonahle degree of confidence. 


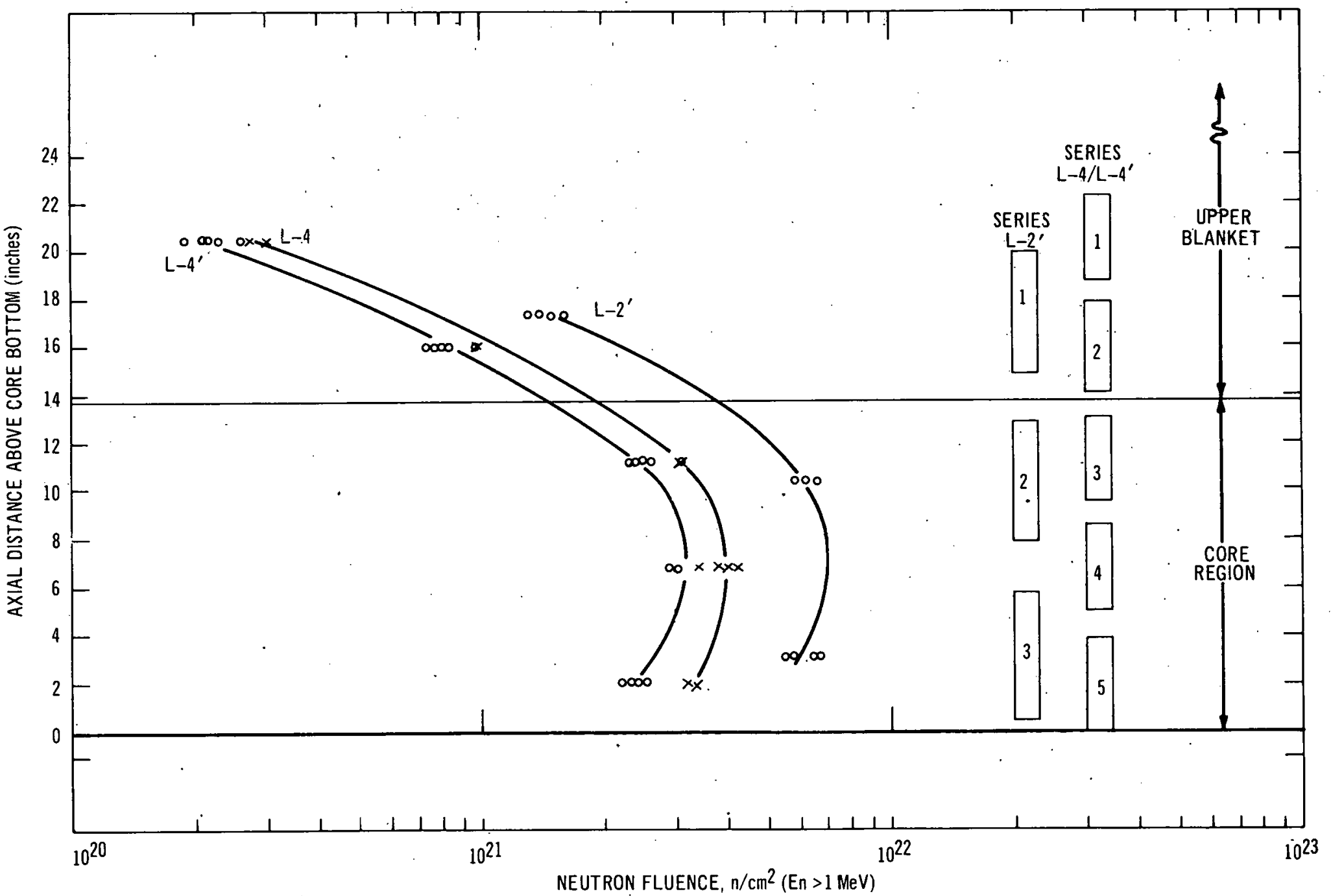

Figure 4-23. EBR-II Neutron Fluence Distribution for Capsule Series L-2, L-4, and L-4 ' 


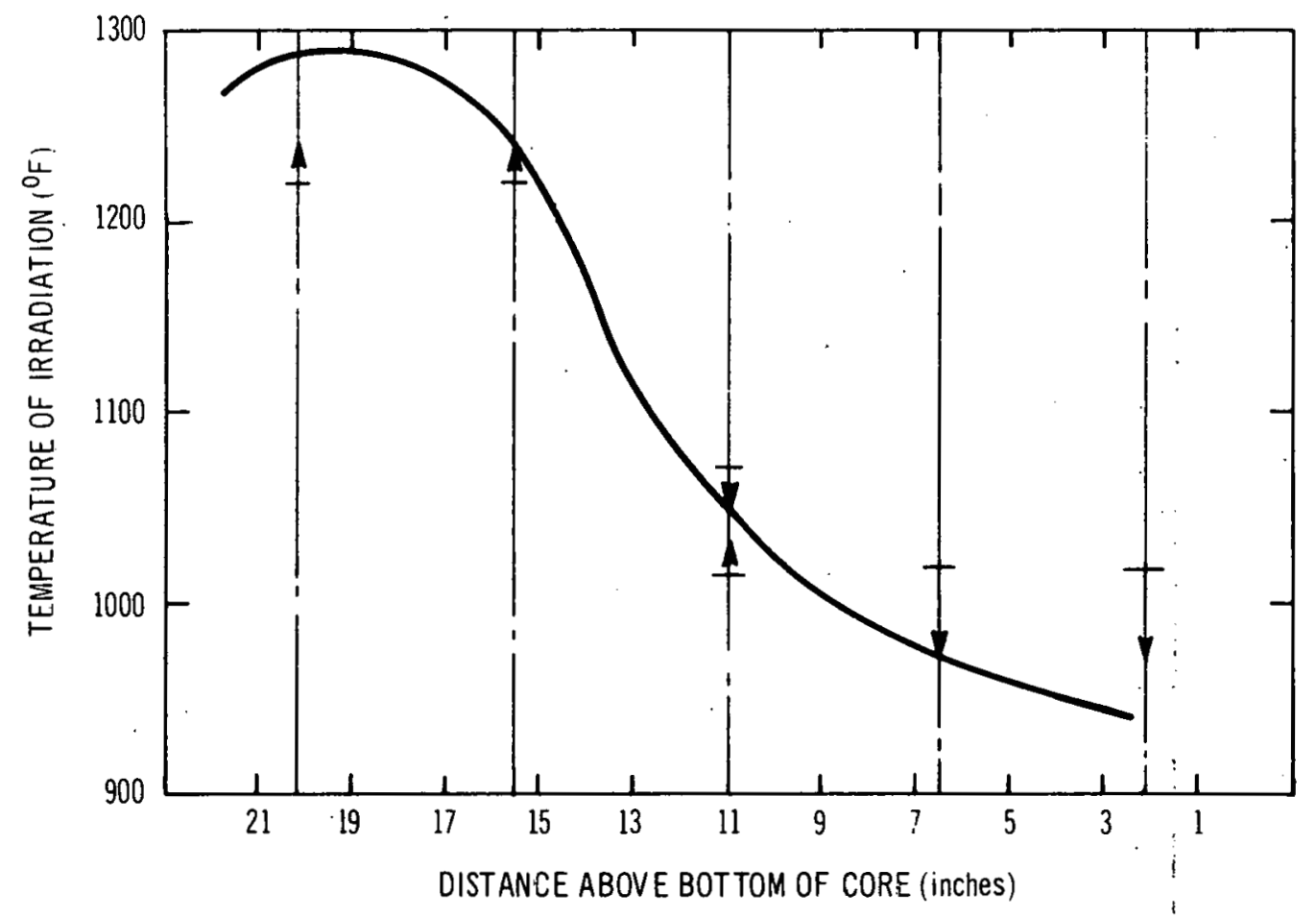

$\frac{O}{2}$

Figure 4-24. Temperature Distribution in Materials Capsule L4B 


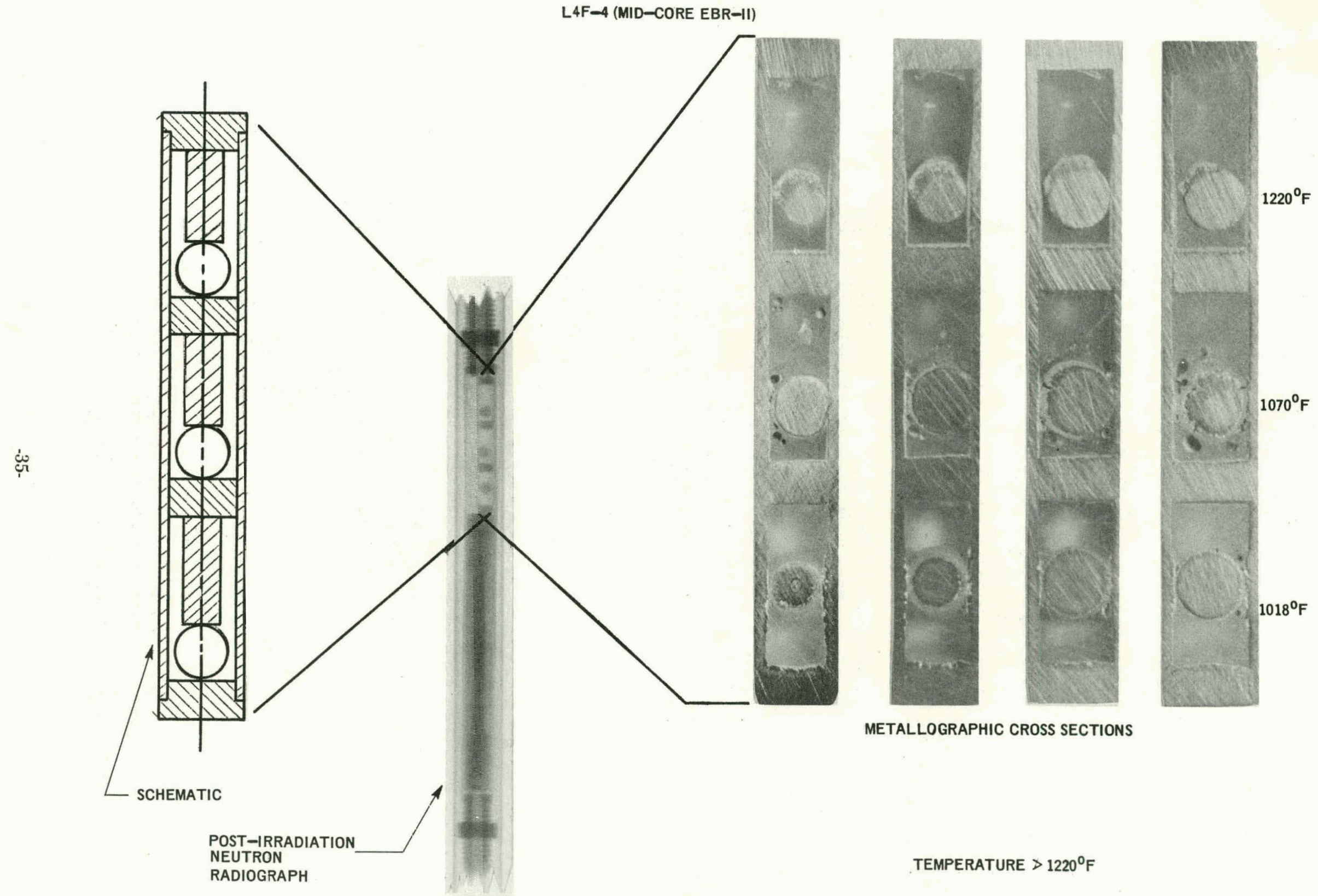

园

Figure 4-25. Metallographic Cross Section, L4F-4 
L20-2 (UPPER CORE)
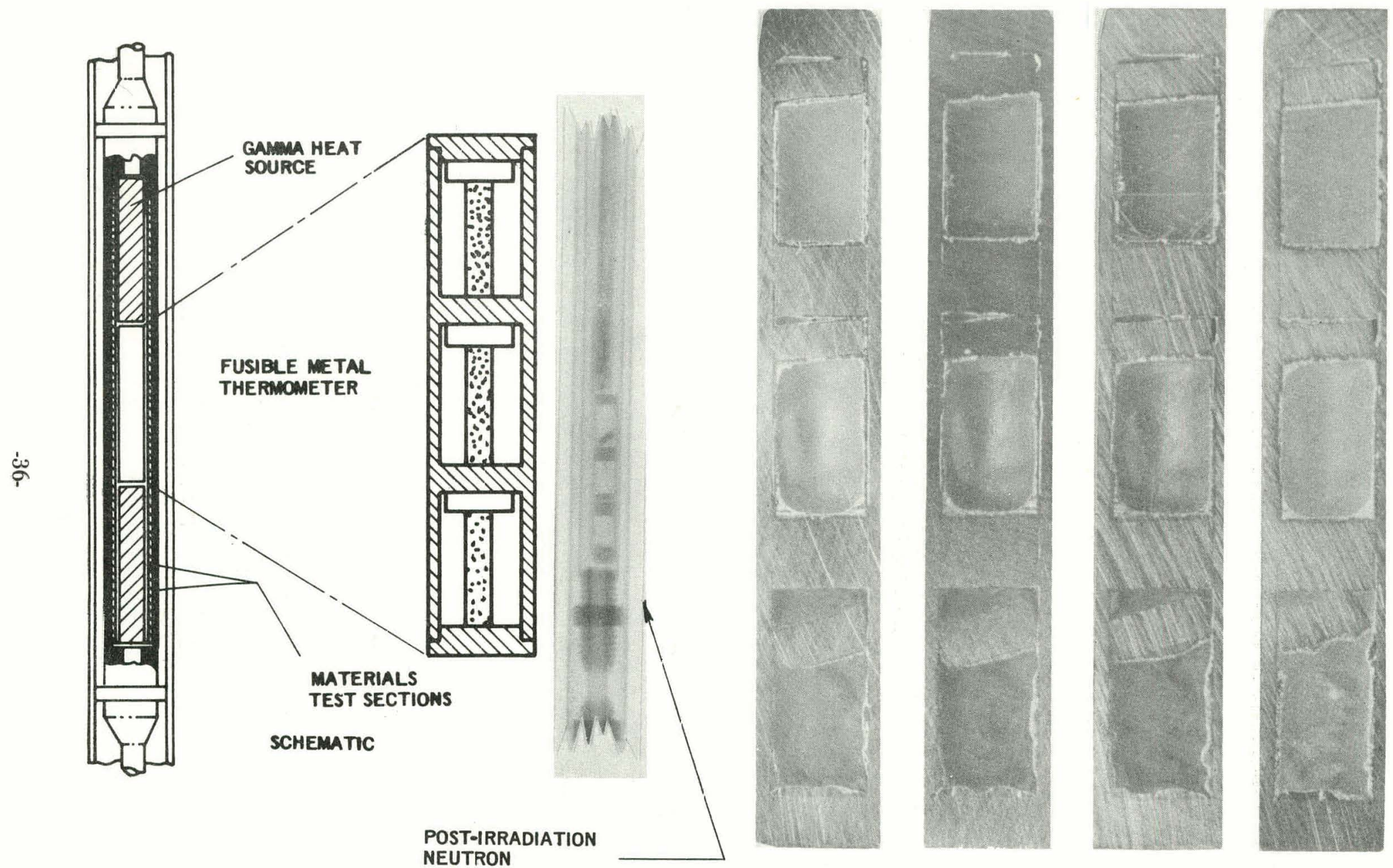

$1220^{\circ} \mathrm{F}$

NEUTRON

METALLOGRAPHIC CROSS SECTIONS

等

TEMPERATURE $>1220^{\circ} \mathrm{F}$

Figure 4-26. Metallographic Cross Section, L20-2 


\section{RESULTS}

Mechanical properties data were obtained from postirradiation tensile (uniaxial) and burst (biaxial) tests, perfiormed at temperatures from 900 to $1500^{\circ} \mathrm{F}$. Optical and electron metallographic techniques were used to support or interpret the results.

\subsection{IN-REACTOR DEFORMATION}

Considerable difficulty was experienced in removing scveral test section arrays from the capsule assembly. Subsequent examination showed the presence of sodium in the annulus between the test sections and the capsule assembly tubc, which prior to irradiation was filled only with argon gas. This indicated that some of the walls of the sodiumfilled tubular sections had been breached during irradiation.

An attempt was made to locate the failure regions by pressurizing the test sections and helium leak-checking at room temperature. Several were located in either a weld joint or in the test section wall. This information is summarized in Tables 5-1 and 5-2. Only eight failures were observed; however, it is believed that, since all capsule assemblies showed evidence of sodium leakage, other test sections had through-cracks which were open only at clevated temperatures.

Micrometer and profilometer measurements were performed on the outside diameter of each of the tubular test sections to determine the extent of deformation that oc. curred during the reactor exposure. These measurements are listed in Tables 5-1 and 5-2 for capsule scries $L-2 '$ and L-4/L-4', respectively. In general, the diametral growth resulting from pre-pressurization was either substantial and localized, or was negligible. Maximum diametral change usually was associated with the in-core test sections, which experienced the highest exposure temperatures. Figure 5-1 shows a profilometer trace for an Inculuy -800 test scction from series L-4', which was located in the upper blanket of the EBR-II. No deformation was observed. However, a profilometer trace from a similar Incoloy 800 test section, located in the core region (Figurc, 5-2), shows lucalized deformation and substantial diametral increase (15\%).

A melallographic examination was made in an effort to establish the failure modc for those specimens that showed through-cracks. Test section LAC-4 (carbideagglomerated Type 316) was selected because a breach in the tube wall had been located in this section using helium-leak detection methodf. The rcsulting plotumicrographs are shown in Figure 5-3. Cracking was observed throughout the section. The failure was intergranular, with many voids locuted at triple points and at grain boundaries. It appears that discrete voids grow and link together to form cracks. As would be expected, these voids and cracks were nearly perpendicular to the principal stress direction. Also evident was substantial sigma formation at triple points and carbides at grain boundaries. Localized necking and intergranular cracking were observed in the seam weld of this test section (Figure 5-4).

Because of the unusual deformation observed in the test sections, an effort was made to recalculate the preirradiation stress conditions and estimate the causes of the in-reactor deformation. It was concluded that the large amounts of deformation observed were due mainly to a higher temperature of irradiation than that used in the initial stress analysis.

The relatively high incidence of cracks in the weld zone of these tubes suggests that welded and drawn tubing may not perform satisfactorily under conditions of internal pressure and low deformation rates. If the weld zone is the weakest area in the material, the applicability of the in-core diametral growth changes is limited as an estimate of incort creep behavior. However, if diametral strains are small, the specimens are useful for post-irradiation testing (uniaxial and biaxial) at medium-range strain rates.

\subsection{BURST TESTS ON EBR-II CAPSULE TUBES}

The tubes used in the encapsulation of all materials and fuel pins irradiated in EBR-II are welded and drawn Type-304 stainless steel, with nominal dimensions of 0.375 inch o.d. and 0.020-inch wall. The material utilized in the tests discussed here had an average ASTM grain size 8 , and chenuical composition as shown in Table 5-3. The tubing was irradiated in the as-received (solution-annealed) condition.

The irradiation history of the capsule tubes is identical to that of the $\mathrm{L}-2$ ' materials capsules, as discussed in subsection 4.3. A representative axial temperature profile and its relation to the fluence profile are shown in Figure 5-5 for capsule tubing containing fuel pins. Post-irradiation metallographic examination of a typical capsule tube revealed that

a. The tube is lightly sensitized throughout the cross section;

b. The grain structure is uniform, with an average grain size of ASTM 7;

c. Neither the outer tube surface, exposed to flowing sodium, nor the inner tube surface, exposed to static sodium, shows any evidence of attack, compositional disturbance, or unusual precipitation behavior.

The as-received material, in comparison, shows austenitic grains with numerous annealing twins, typical of a fully-annealed austenitic stainless steel, and a grain size of ASTM 8. When it is realized that the two tubing sections are not directly comparable except in heat number, the difference in grain size between as-received and irradiated material is not considered significant. Representative microstructures of as-received and irradiated materials are shown in Figure 5-6. 
TABLE 5-1

DIAMETRAL GROWTH OF TUBULAR TEST SECTIONS FROM SERIES L-2'

Test Section $^{(c)}$

Designation

L-2K-1

$\mathrm{L}-2 \mathrm{~K}-2$

L-2K-8(a)

L-2M-1

L-2M-2

L-2M-3

L-20-1

L-2O-2(b)

L-2O-3

L-2P-1

L-2P-2

L-2P-3

L-2Q-1

L-2Q-2

L-2Q-3

$$
\text { Material (d) }
$$

\author{
Maximum Diametral \\ Growth (\%)
}

Neutron Exposure $(\mathrm{f})$

$(E n>1 \mathrm{MeV}) \mathrm{n} / \mathrm{cm}^{2}$

$\times 10^{21}$

(a) Failure located in weld zone between autoclave nipple and tube.

(b) Failure in test section; location unidentified.

(c) (-1) indicates top test section (upper blanket region).

(-2) indicates middle test section (in corc).

$(-3)$ indicates bottom test section (in core).

(d) Material was in as-received condition (mill annealed).

(e) Measurements made with micrometer; all other measurements werc pcrformed with a profilometer.

(f) The L-2' series of materials capsules have 207 effective full-power days (EFPD) in the EBR-II.

$\begin{array}{ll}\text { None } & 1.3 \\ 0.8(\mathrm{e}) & 6.7 \\ 1.0^{(\mathrm{e})} & 6.2 \\ \text { None } & 1.3 \\ 14.4 & 6.7 \\ 3.6 & 6.2 \\ 1.0^{(\mathrm{e})} & 1.3 \\ 9.6^{(\mathrm{e})} & 6.7 \\ 6.4 & 6.2 \\ 1.6 & 1.3 \\ 14.8 & 6.7 \\ 14.8(\mathrm{e}) & 6.2 \\ 0.4(\mathrm{e}) & 1.3 \\ 12.4 & 6.7 \\ 8.0 & 6.3\end{array}$

1.3

6.2

1.3

6.7

6.2

13

6.7

6.2

1.3

6.7

6.2

1.3

6.3 
TABLE 5:2

DIAMETRAL GROWTH OF TUBULAR TEST SECTIONS FROM SERIES L-4 AND L-4'

\begin{tabular}{|c|c|}
\hline $\begin{array}{c}\text { Test Section } \\
\text { Designation }\end{array}$ & Material $^{(d)}$ \\
\hline L-4A-1 & Incoloy-800 \\
\hline L-4A-2 & Incoloy -800 \\
\hline L-4A-3 & Incoloy-800 \\
\hline $\mathrm{L}-4 \mathrm{~A}-4^{(\mathrm{a})}$ & Incoloy-800 \\
\hline L-4A-5 & Incoloy -800 \\
\hline L-4B-1 & Incoloy-800 \\
\hline $\mathrm{L}-4 \mathrm{~B}-2$ & Incoloy -800 \\
\hline L-4B-3 ${ }^{(a)}$ & Incoloy-800 \\
\hline$L-4 B-4$ (a) & Incoloy-800 \\
\hline L-4B-5 (a) & Incoloy -800 \\
\hline L-4C-1 & Type 316 \\
\hline $\mathrm{L}-4 \mathrm{C}-2$ & Type 316 \\
\hline L-4C-3 & Type 316 \\
\hline $\mathrm{L}-4 \mathrm{C}-4$ & Type 316 \\
\hline L-4C-5 & Type 316 \\
\hline L-4D-1 & Type 316 \\
\hline L-4D-2 & Type 316 \\
\hline L-AD-3 & Type 316 \\
\hline L-4D-4 & Type 316 \\
\hline L-4D-5 & Type 316 \\
\hline L-4E-1 & Type 347 \\
\hline L-4E-2 & Type 347 \\
\hline $\mathrm{L}-4 \mathrm{E}-3$ & Type 347 \\
\hline L-4E-4 & Type 347 \\
\hline L-4E-5 & Type 347 \\
\hline L-4F-1 & Type 304 \\
\hline L-4F-2 & Type 304 \\
\hline L-4F-3 & Type 304 \\
\hline $\mathrm{L}-\mathbf{4} \mathbf{F}-\mathbf{4}$ & Type 304 \\
\hline L-4F-5 & Type 304 \\
\hline L-4G-1 (2) & Type 321 \\
\hline L-4G-2 & Type 321 \\
\hline$L-1 G-3$ & Type 321 \\
\hline $\mathrm{L}-4 \mathrm{G}-4$ & Type 321 \\
\hline L-4G-5 & Type 321 \\
\hline
\end{tabular}

\section{Maximum Diametral \\ Growth (\%)}

None

None

3.6

15.2

10.0

None

None

8.8

7.2

2.8

None

None $(f)$

$1.0^{(\mathrm{e})}$

$5.2^{(\mathrm{e})}$

$2.0(\mathrm{f})$

None ${ }^{(f)}$

None ${ }^{(e)}$

-(f)

None ${ }^{(f)}$

-(f)

None

None

$16.8(\mathrm{f})$

20.8

$16.8(f)$

-(g)

None

None

None

None

1.2

1.2

1.2

1.2

1.2
Neutron Exposure $(\mathrm{g})$

$($ En $>1 \mathrm{MeV}) \mathbf{n} / \mathrm{cm}^{2}$

$\times 10^{21}$.

0.22

0.76

2.4

3.0

2.5

0.22

0.76

2.4

3.0

2.5

0.3

0.96

3.1

3.9

3.3

0.3

0.96

3.1

3.9

3.3

0.22

0.76

2.4

3.0

2.5

0.22

0.76

2.4

3.0

2.5

0.22

0.76

2.4

3.0

2.5

(a) Failure located in tube wall.

(b) Failure located in weld zone between autoclave nipple and tube.

(c) (-1) indicates top test section (upper blanket region).

(-2) indicates second test section (upper blanket region).

$(-3)$ indicates middle test section (in core).

(-4) indicates fourth test section (in core).

(-5) indicates bottom test section (in core).

(d) Material is in carbide-agglomerated condition (1650F-24, hours).

(e) Measurements made with micrometer; all other measurements were performed with a profilometer.

(f) Test section was scratched and possibly deformed during disassembly.

(g) All materials capsules have 81.6 effective full power days (EFPD) in EBR-II except Type $316(\mathrm{~L}-4 \mathrm{C}$ and $\mathrm{L}-4 \mathrm{D})$ ) which have $119 \mathrm{EFPD}$. 


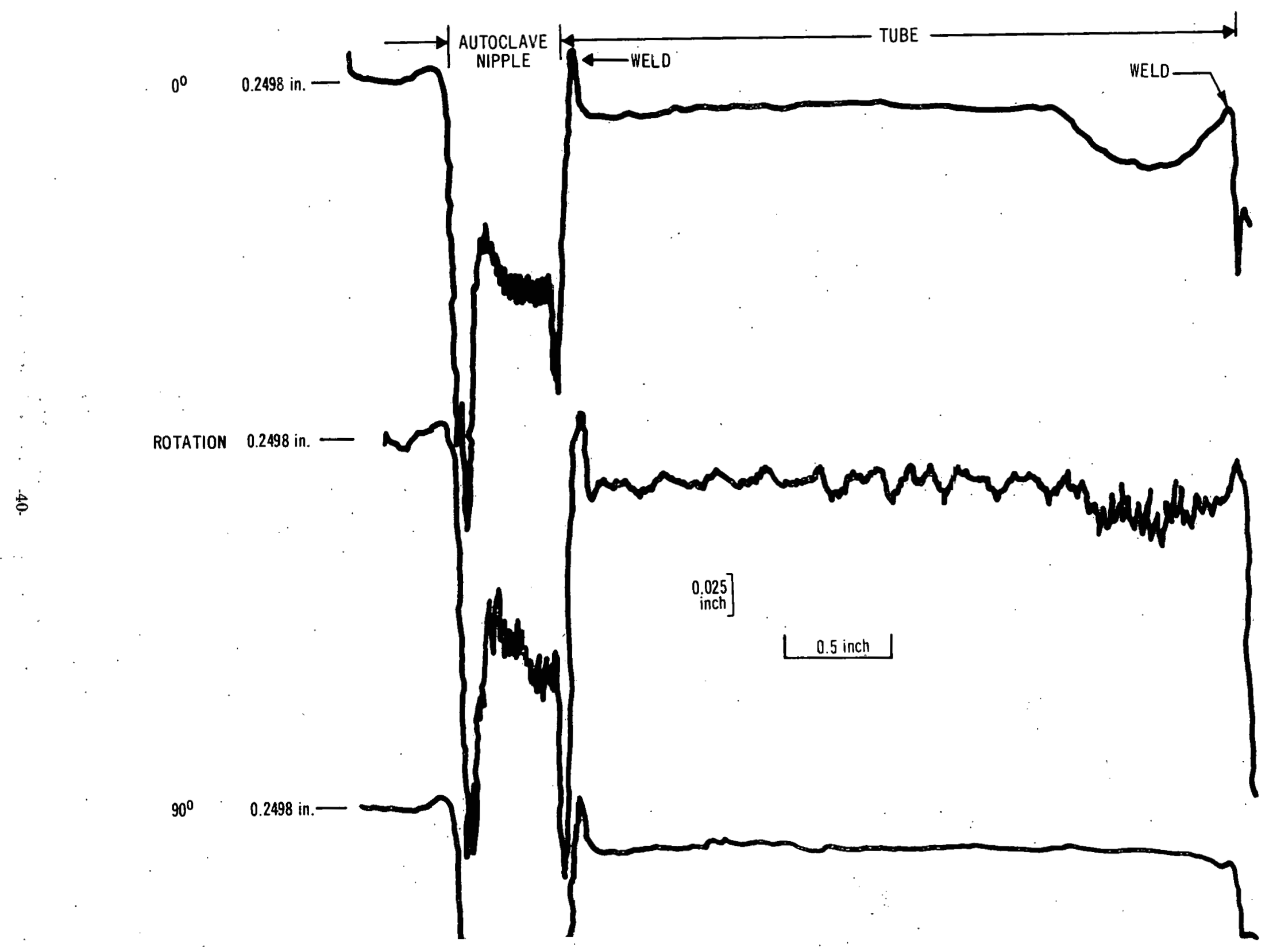

Figure 5-1. Post-Irradiation Profilometer Trace for Tubular Test Section L-4A-1 (Incoloy-800) 


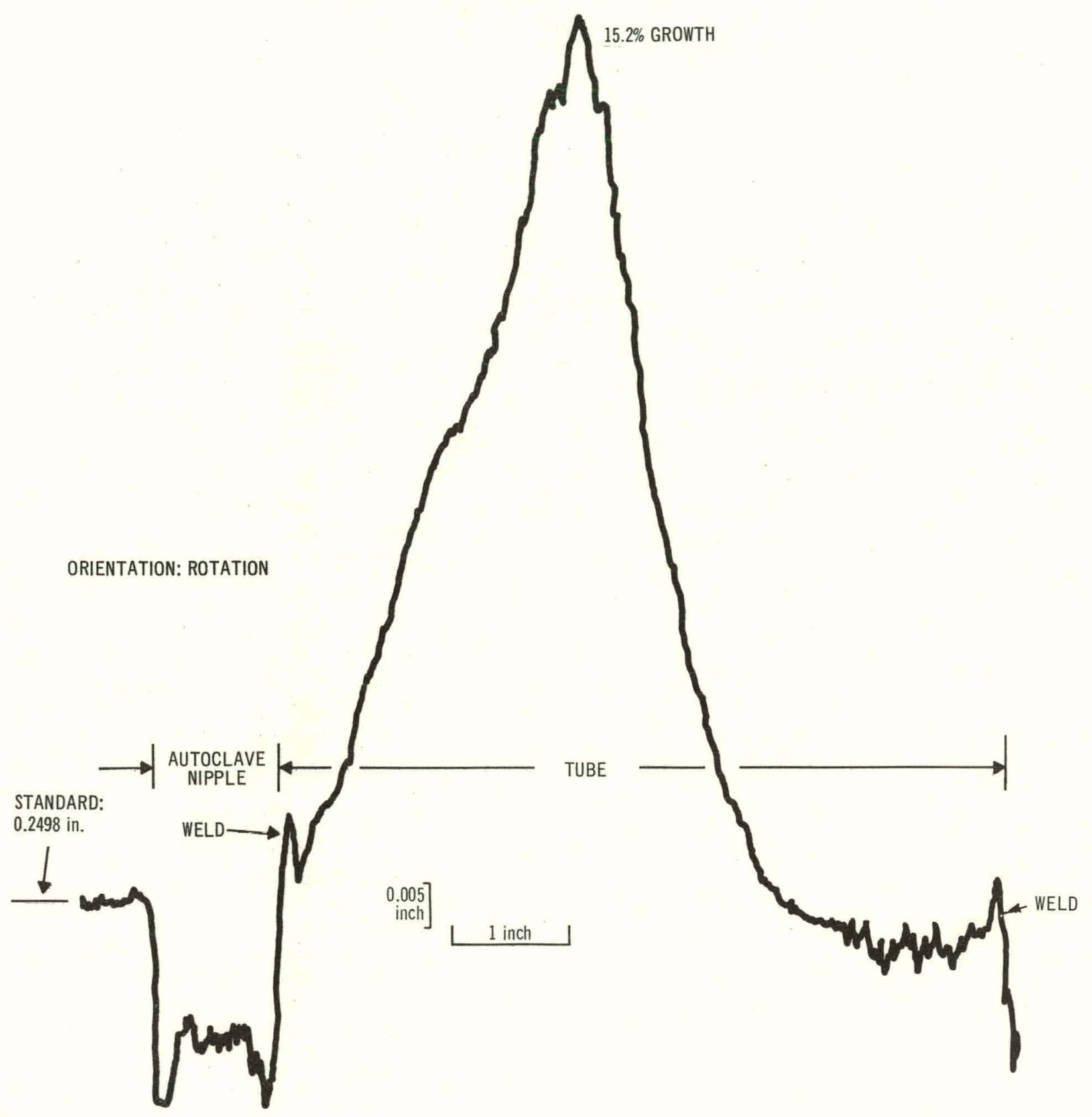

Figure 5-2. Post-Irradiation Profilometer Trace for Tubular Test Section L-4A-4 (Incoloy-800) 


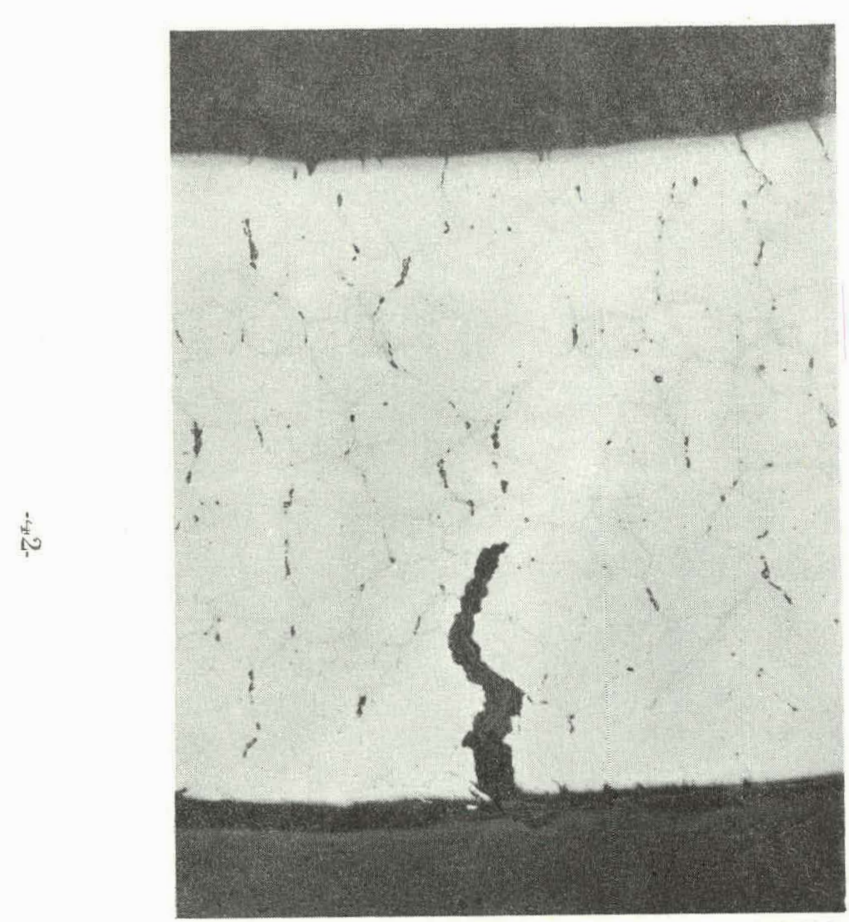

(a) ETCH: VILELLA

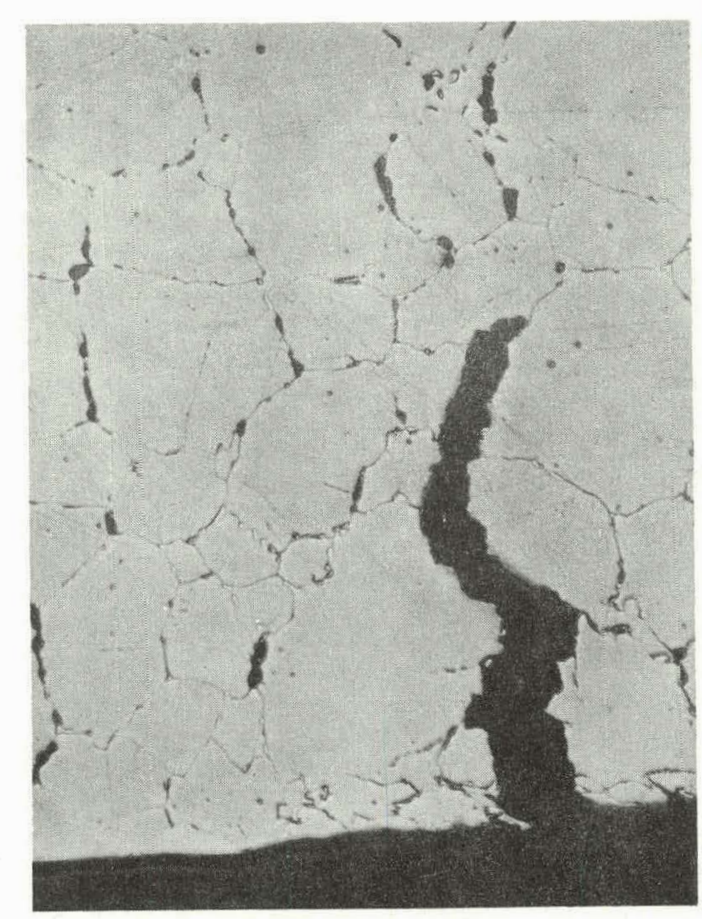

(b) ETCH: VILELLA

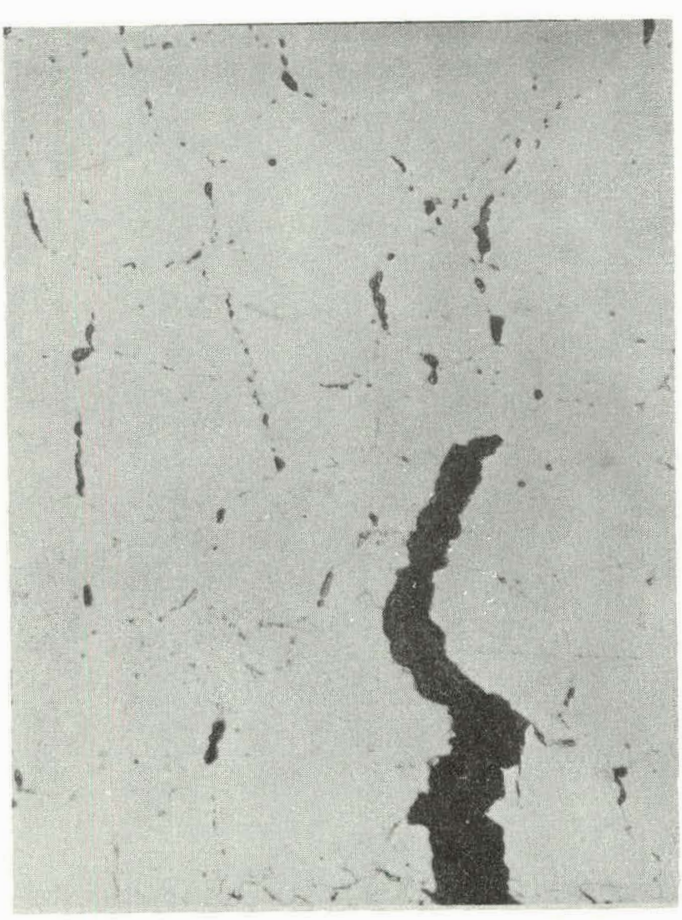

(c) ETCH: MURAKAMI 


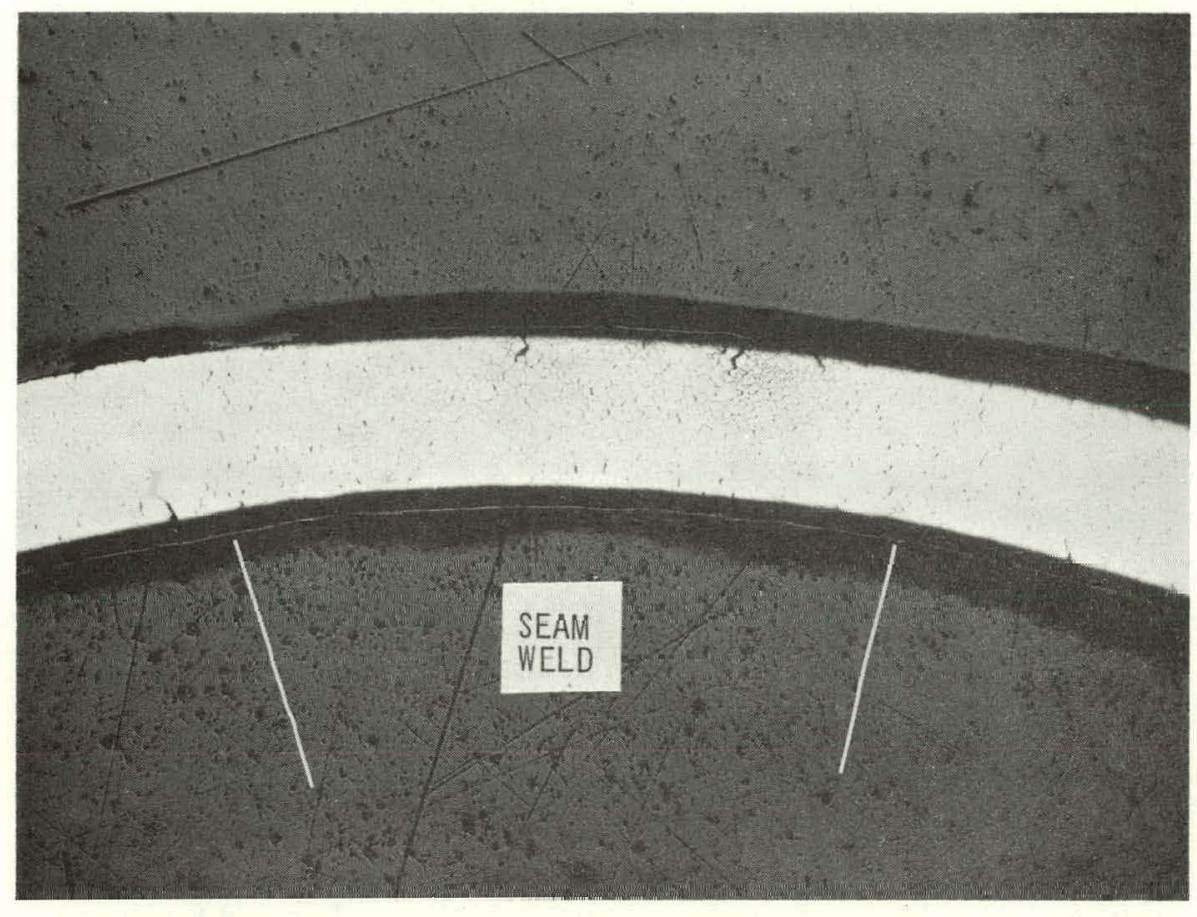

(a) ETCH: VILELLA

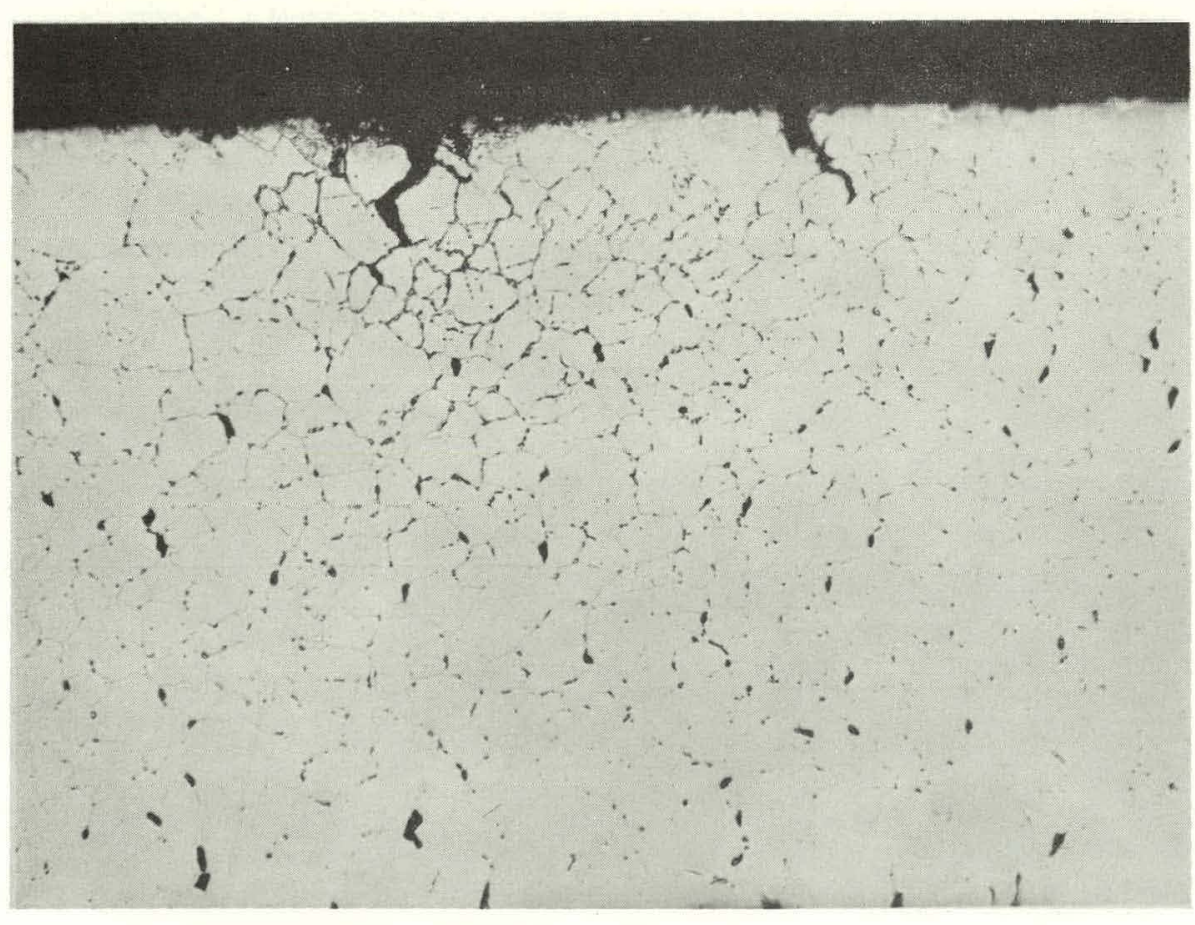

(b) ETCH: VILELLA

250X

Figure 5-4. Transverse Section of Tubular Test Section L-4C-4. (Type 316) Seam Weld Region 
(iE.AP-10066

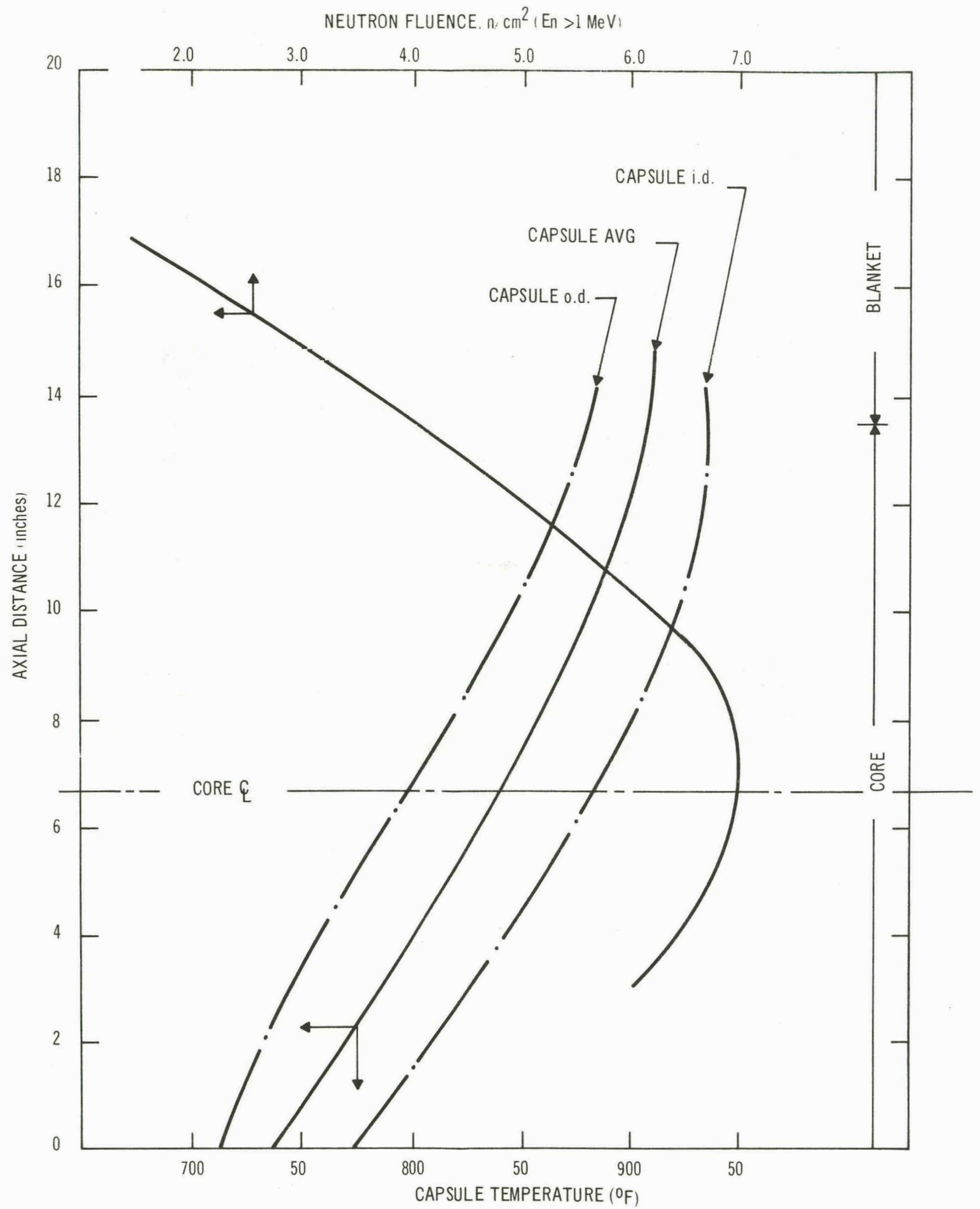

Figure 5-5. Exposure History of F'2 Capsule Tubes in EBR-II 


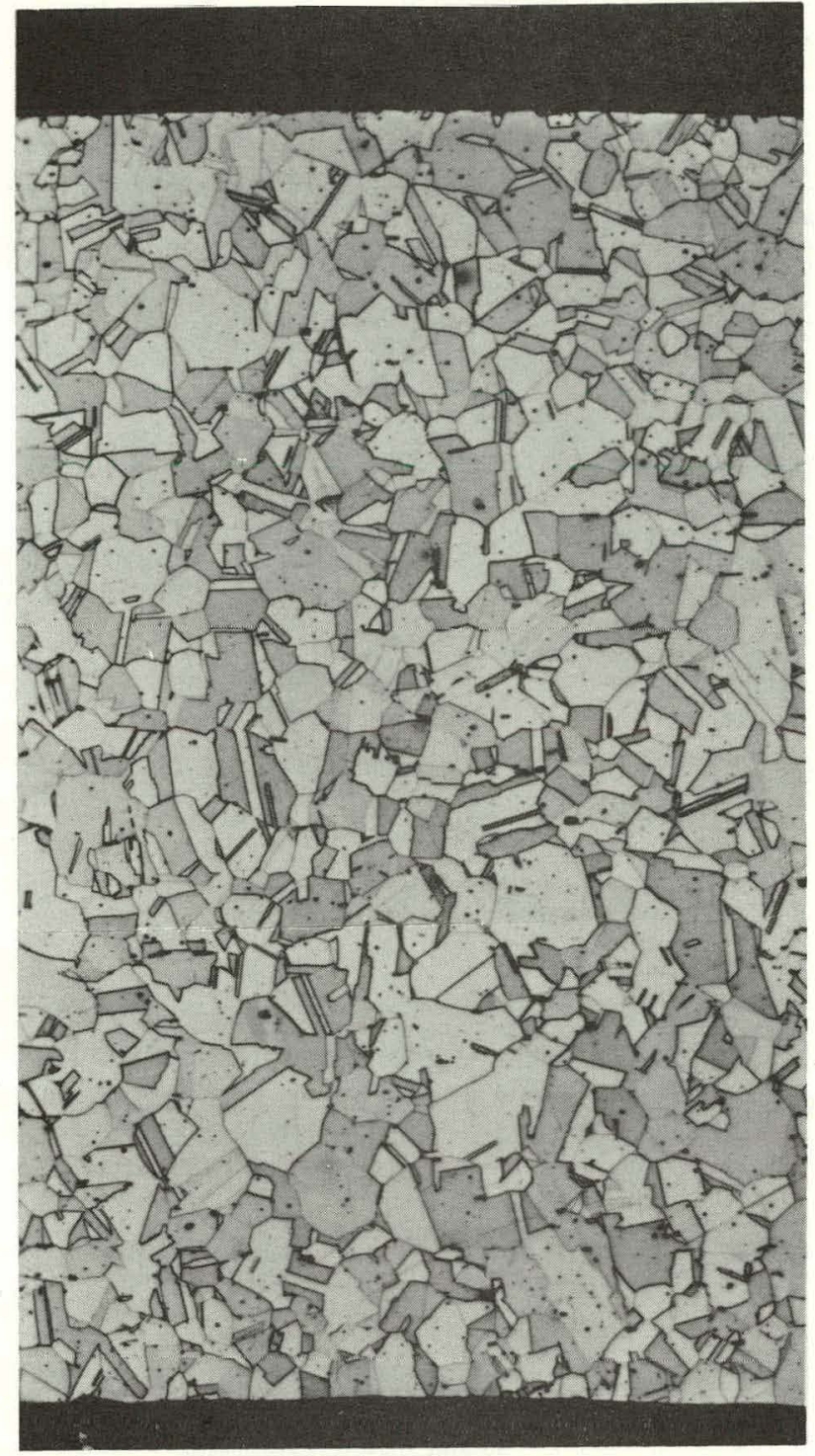

AS-RECEIVED TUBING,

MODIFIED GLYCEREGIA ETCH, 250X

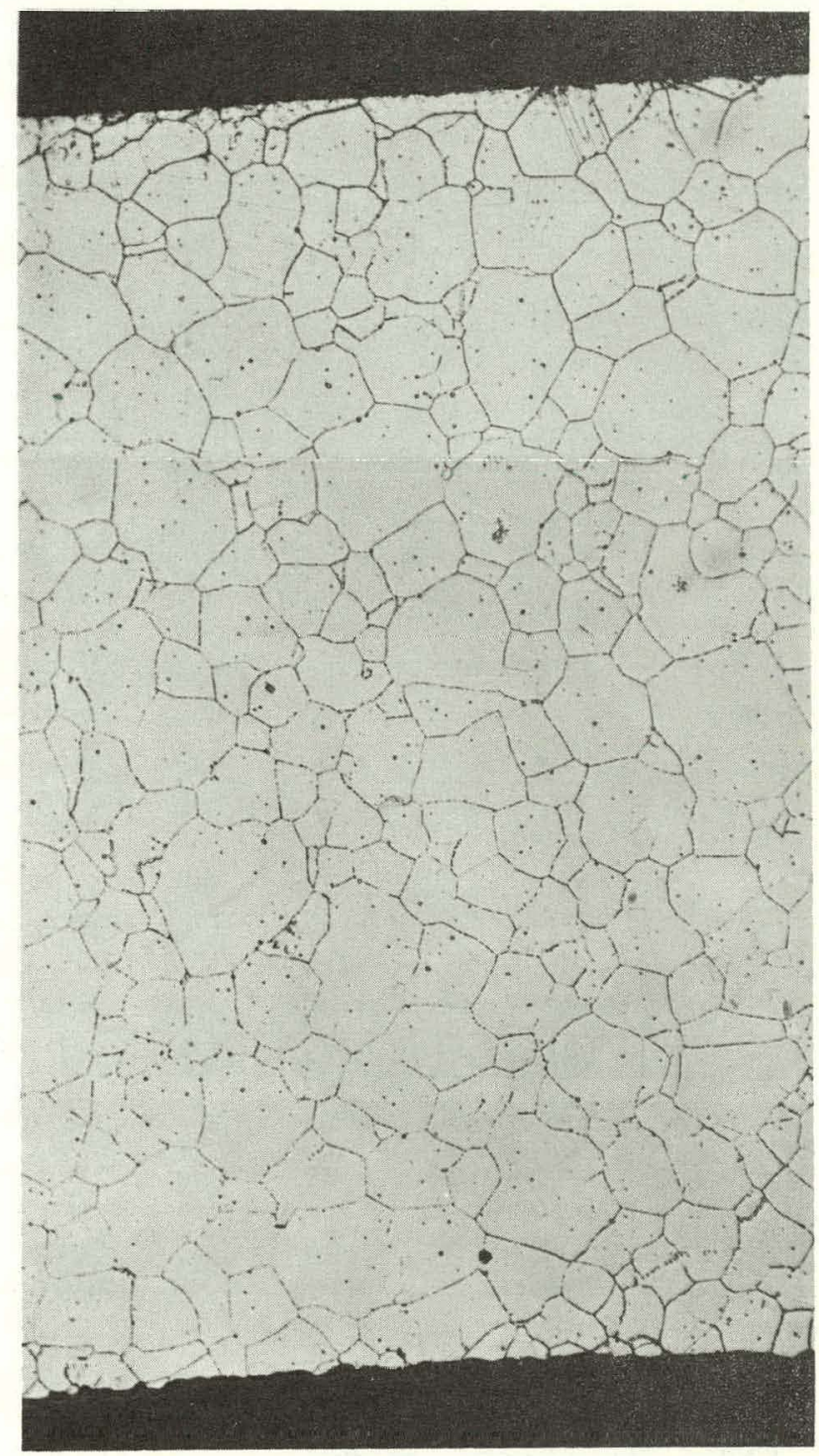

IRRADIATED TUBING

OXALIC ACID ETCH, 250X

IRRADIATED SPECIMEN IS FROM THE

CAPSULE TUBE OF PIN F2Q

Figure 5-6. Microstructure of Type-304 Capsule Tubes Used in FCR Fuels Irradiation Capsule Series F2 
TABLE 5-3

CERTIFIED CHEMISTRY OF TYPE-304 CAPSULE TUBE

HEAT NO. 136272

$\begin{array}{lllr}\text { Carbon } & 0.07 & \text { Chromium } & 18.46 \\ \text { Manganese } & 1.55 & \text { Nickel } & 9.35 \\ \text { Phosphorus } & 0.027 & \text { Iron } & \text { Balance } \\ \text { Silicon } & 0.48 & \text { Sulfur } & 0.019\end{array}$

In view of the calculated time-temperature history of the specimen during the irradiation test, the degree of sensitization observed is somewhat surprising. However, the fact that the capsule was stored for an extended period of time in reactor ambient sodium $\left(\sim 700^{\circ} \mathrm{F}\right)$ could account for such an occurrence.

\subsubsection{Test Procedure}

Test specimens were selecled from two locations on the capsule tubes, representing regions of fairly uniform fluence over the length of the specimen: the mid-core or peak flux region, and the blanket region. Additional specimens were selected from the upper and lower core, as necessary to strengthen the data for a given test parameter.

The burst test apparatus used in this investigation is shown schematically in Figure 5-7. It was designed to provide a linear increase in pressure with time, pressure being monitored by recording the output signal of a transducer. The unit is capable of attaining a pressure of 10,000 psi.

Each test specimen was loaded with a solid rod (nominally, 0.325-inch diameter) to reduce the internal volume of the piece, thereby reducing the energy release on failure. The specimens were attached to the pressure line and sealed with "Swagelok" fittings. Specimens were heated in air in a resistance furnace, and stabilized at temperature prior to pressurization. ${ }^{*}$ Specimens were run at a pressurizing rate of $200 \mathrm{psi} / \mathrm{min}$. Burst-testing was performed at $900,1100,1300$ and $1500^{\circ} \mathrm{F}$.

\subsubsection{Results and Discussion}

Macroscopic examination of the sections after testing revealed that the failures in irradiated tubing, some of which are shown in Figure 5-8, were predominantly lenticular in shape, with crack propagation occurring longitudinally. This configuration suggests that failure occurred along the seam weld. The burst region on unirradiated specimens, on the other hand, was characterized by a severe transverse tearing which, in most cases, completely severed the tube section, as can be seen in Figure 5-9. Detailed metallographic examination of these control

* The time at temperature prior to pressurization was approximately 30 minutes. tubes showed that failure was not associated with the seam weld. Cross sections of a representative test specimen are shown in Figure 5-10.

The experimental and analytical burst data are listed in Table 5-4 and plotted in Figure 5-11. Thin wall analysis (hoop strength $=\mathrm{PD} / 2 \mathrm{t}$ ) was applied to convert burst pressure $\mathrm{P}$ to hoop or tangential rupture strength. The data show a marked increase in hoop strength with decreasing test temperature, relative to that of the unirradiated controls. In all cases, the specimens irradiated in the core region of EBR-II exhibited higher hoop strength than those exposed in the blanket. Extrapolation of the data shows that the hoop strength of irradiated and control specimens converge at approximately $1600^{\circ} \mathrm{F}$, indicating complete recovery at this temperature. This work is in close agreement with that of Holmes and Irvin (Ref. 7), who observed that hardening of Type-304 stainless steel in a fast flux (measured by $0.2 \%$ offset yield stress) is stable to $0.67 \mathrm{~T}_{\mathrm{m}}$ ( 1600 $\left.0^{\circ} \mathrm{F}\right)$. Recent studies, performed at Argonne National Laboratory (ANL) on Type-304L stainless steel irradiated to $1.4 \times 10^{22} \mathrm{n} / \mathrm{cm}^{2}$ (total) in EBR-II (Ref. 8,9), show a similar change in rupture strength with test temperature and indicate that irradiation-induced strengthening in this modified alloy is completely removed at approximately $1400^{\circ} \mathrm{F}$. This lower recovery temperature may be associated with the higher temperature achieved by the ANI, cladding specimens. A comparison of ANL and GE data is shown in Figure 5-12.

The effect of irradiation on the elevated temperature ductility of Type-304 stainless steel is indicated in Figure 5-13. Diametral fracture strain values, calculated from micrometer measurements adjacent to the fracture tip, are listed in Table 5-5. Although the spread in the data is somewhat large, the measurements show a very definite reduction in elevated-temperature ductility with irradiation. The data further show an increase in ductility with test temperature to $1300^{\circ} \mathrm{F}$, with an apparent reduction above $1300^{\circ} \mathrm{F}$. Although the range of test temperatures was insufficient to establish a minimum ductility temperature, previous work (Ref. 8,9 ) has shown a minimum ductility at approximately $900^{\circ} \mathrm{F}$ for irradiated Type-304 stainless steel, with a slight recovery above this temperature. It is 


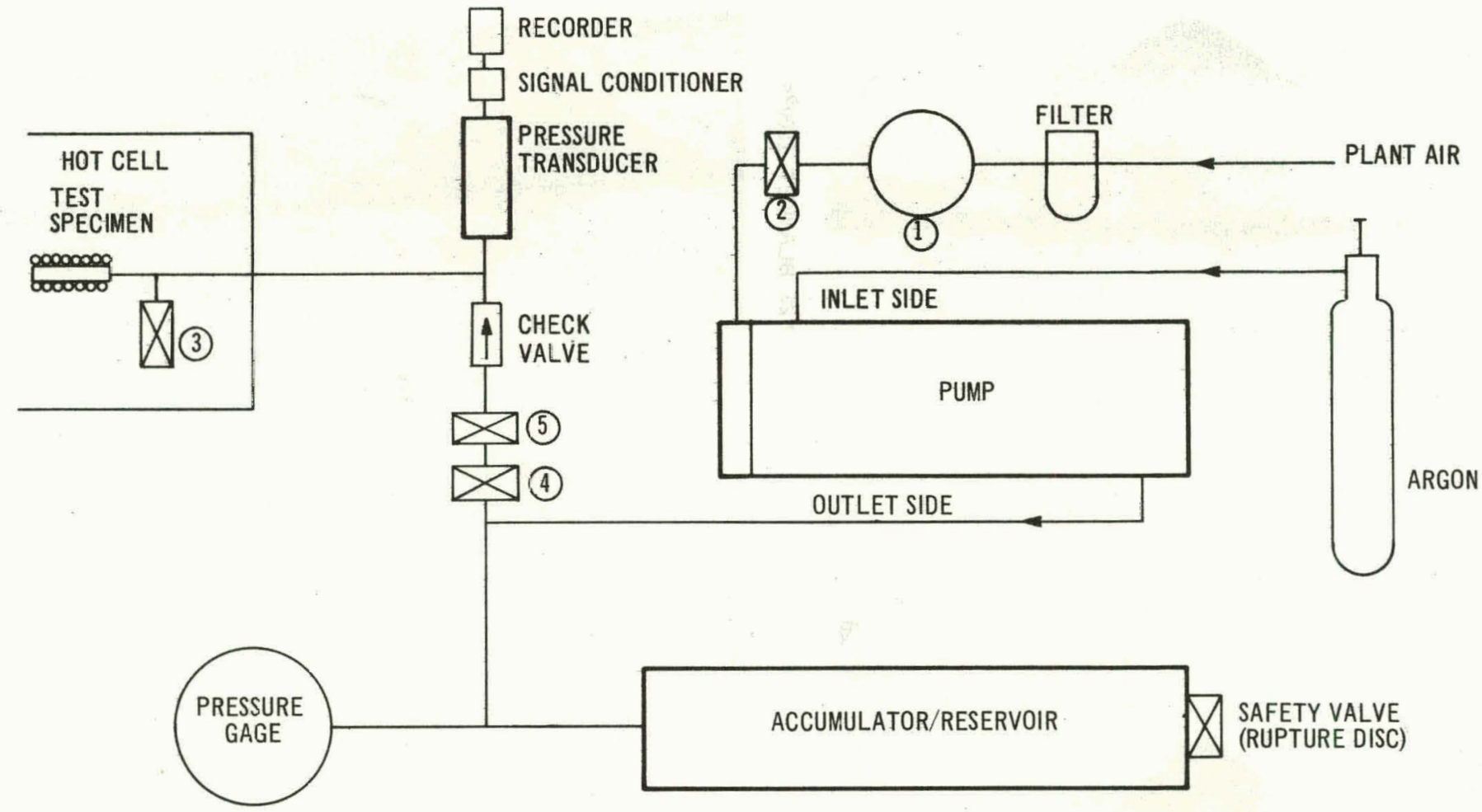

(1) PLANT AIR REGULATOR AND GAGE

(2) PLANT AIR SHUTOFF VALVE

(3) SYSTEM VENT VALVE

(4) SYSTEM SHUTOFF VALVE

(5) Metering VAlve 


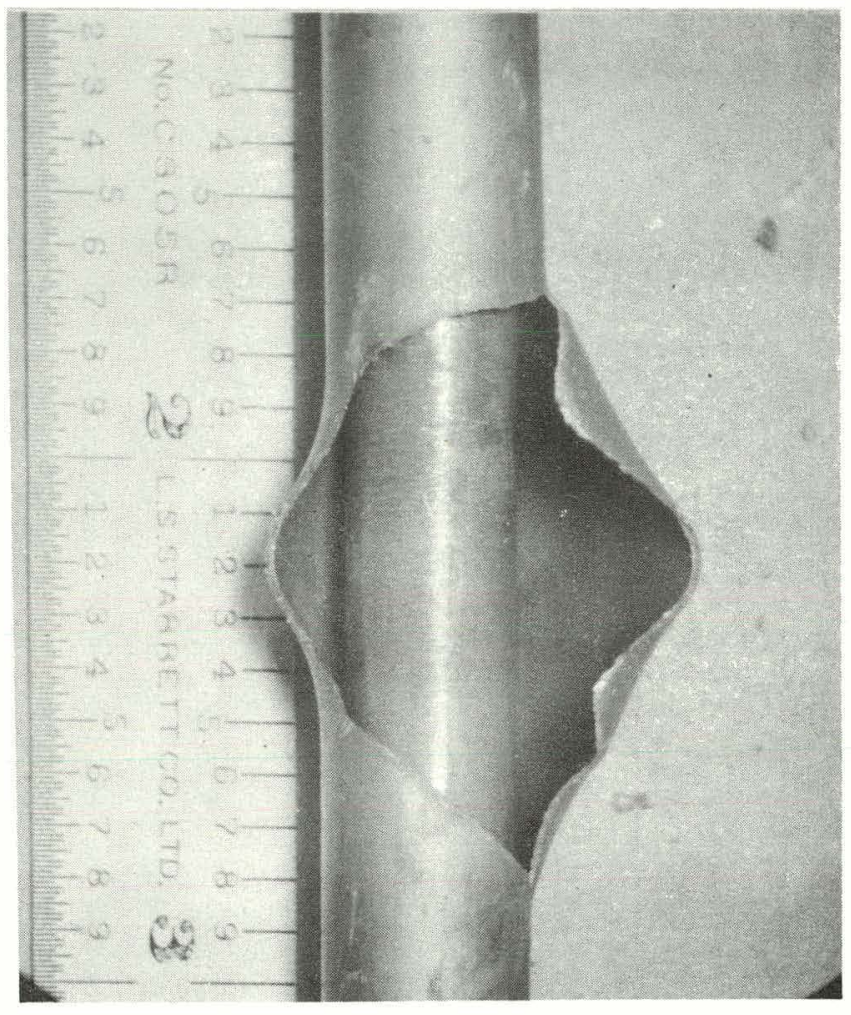

F2E, BLANKET, $1300^{\circ} \mathrm{F}$

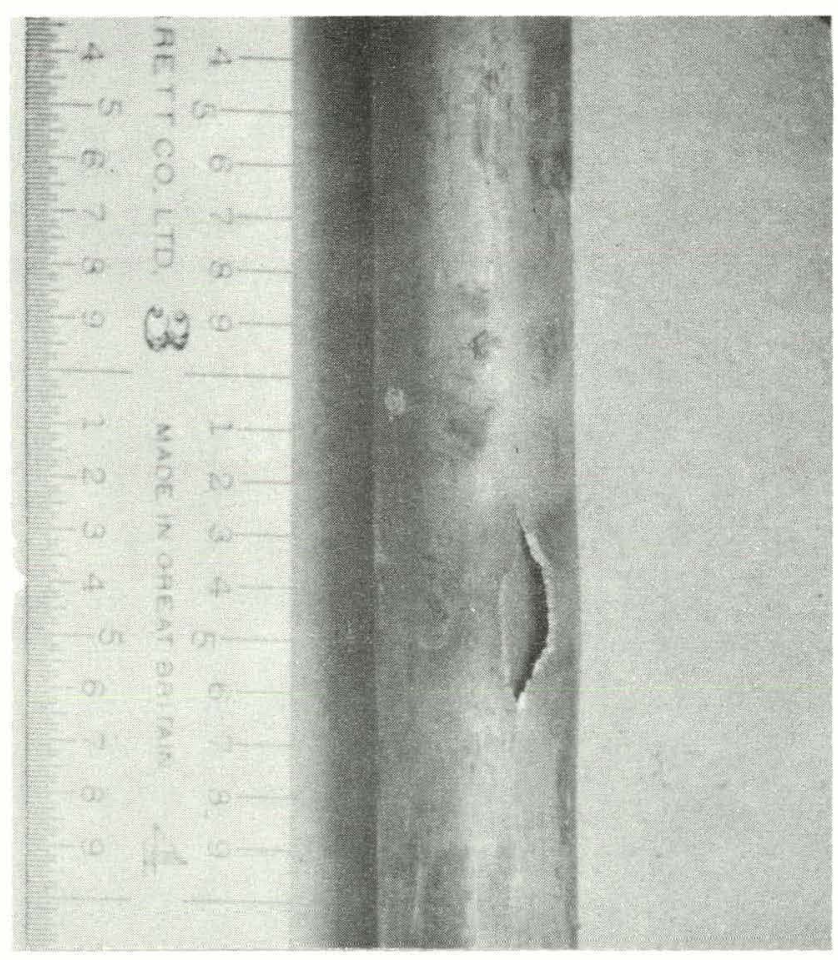

F2E, CORE, $1300^{\circ} \mathrm{F}$

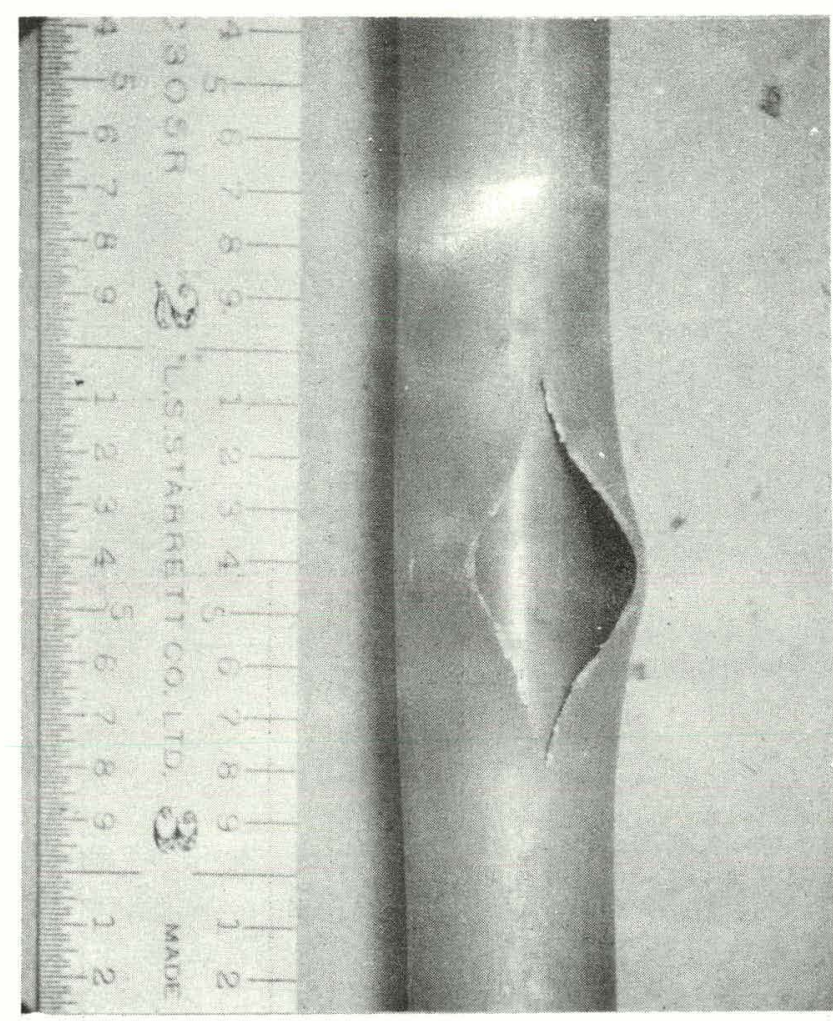

F2S. BLANKET. $1500^{\circ} \mathrm{F}$

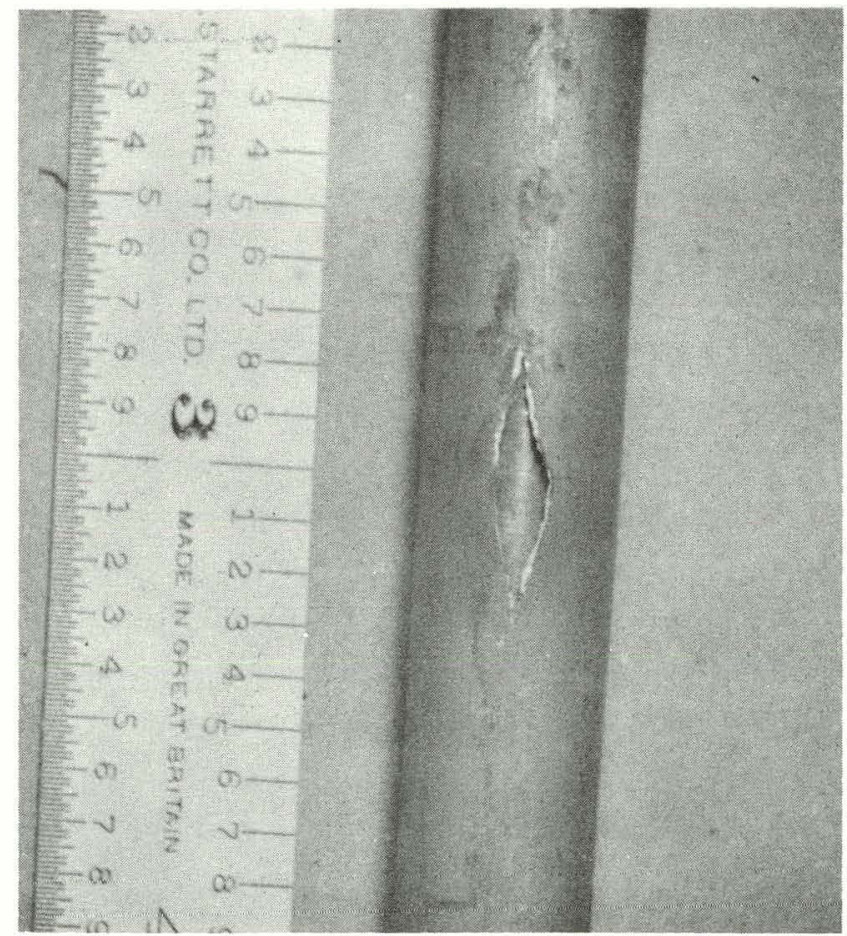

F2S, CORE, $1500^{\circ} \mathrm{F}$

Figure 5-8. Rupture Characteristics of Irradiated Type-304 Burst Specimens 
GEAP-10066
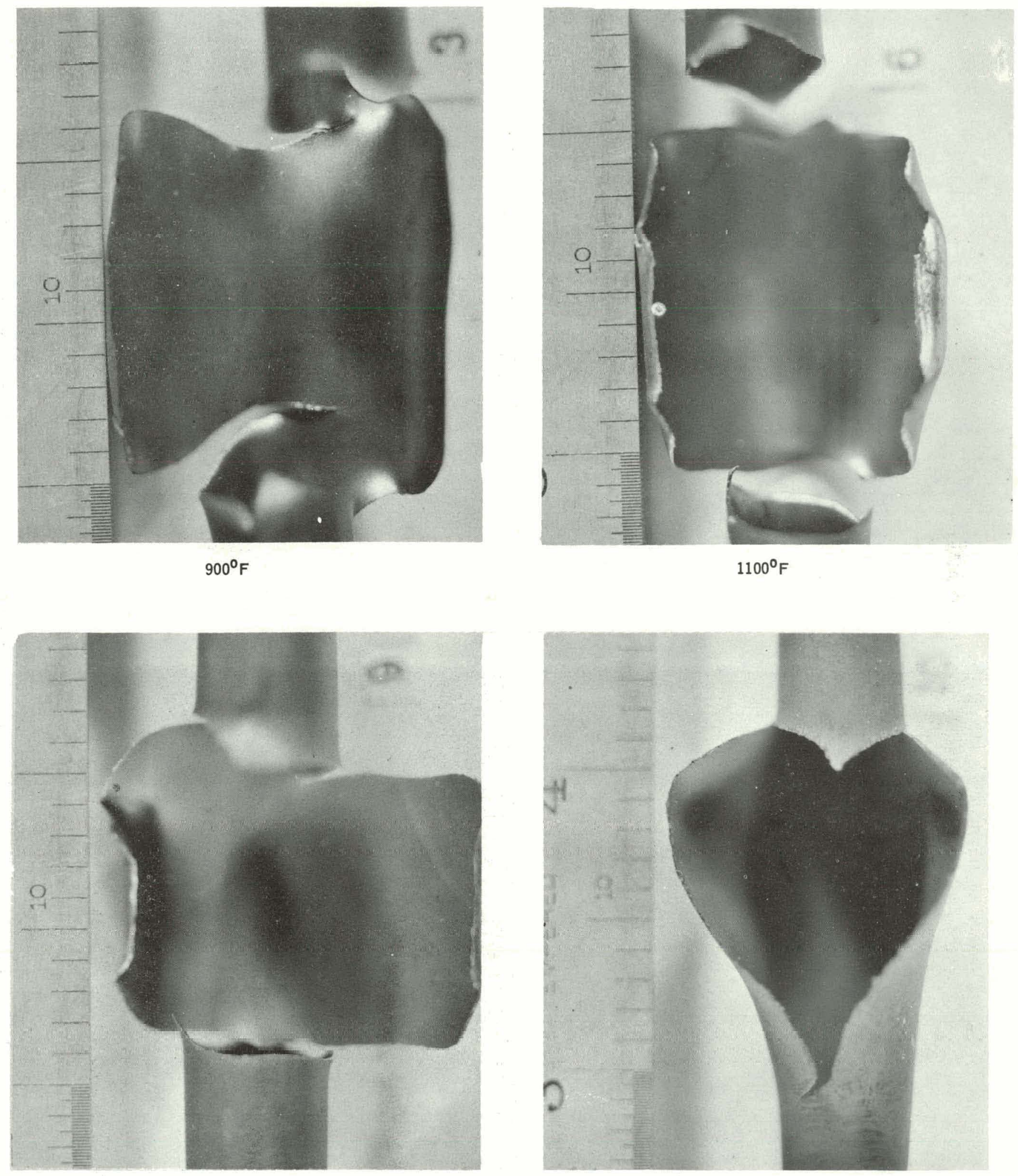

$1300^{\circ} \mathrm{F}$

$1500^{\circ} \mathrm{F}$

Figure 5-9. Rupture Characteristics of Unirradiated Type-304 Burst Specimens 


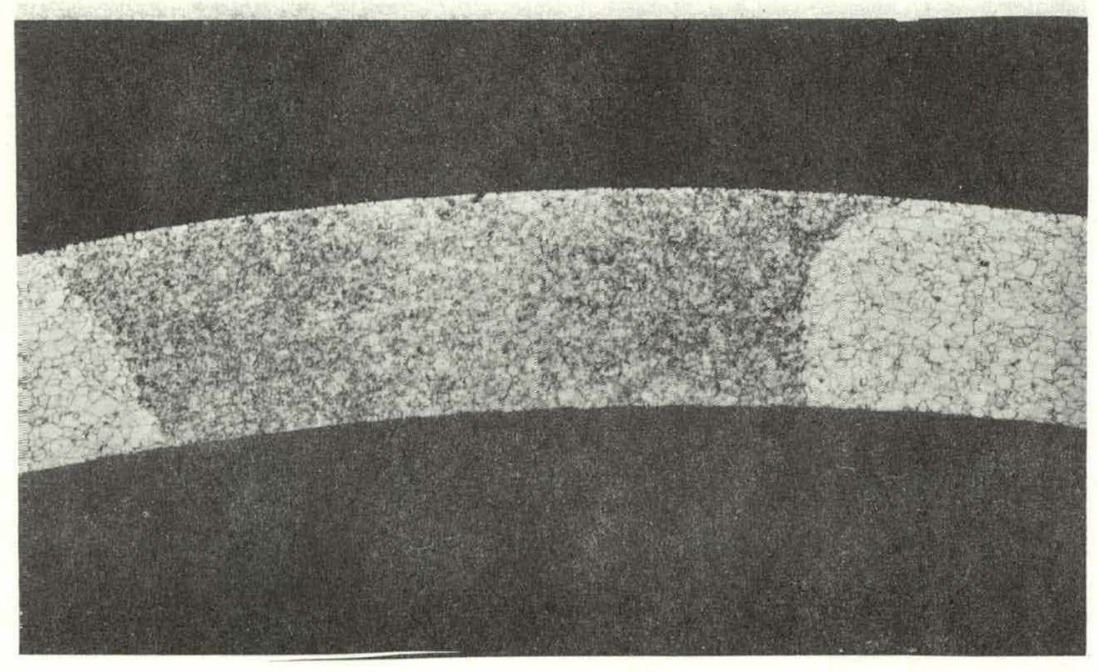

$50 x$
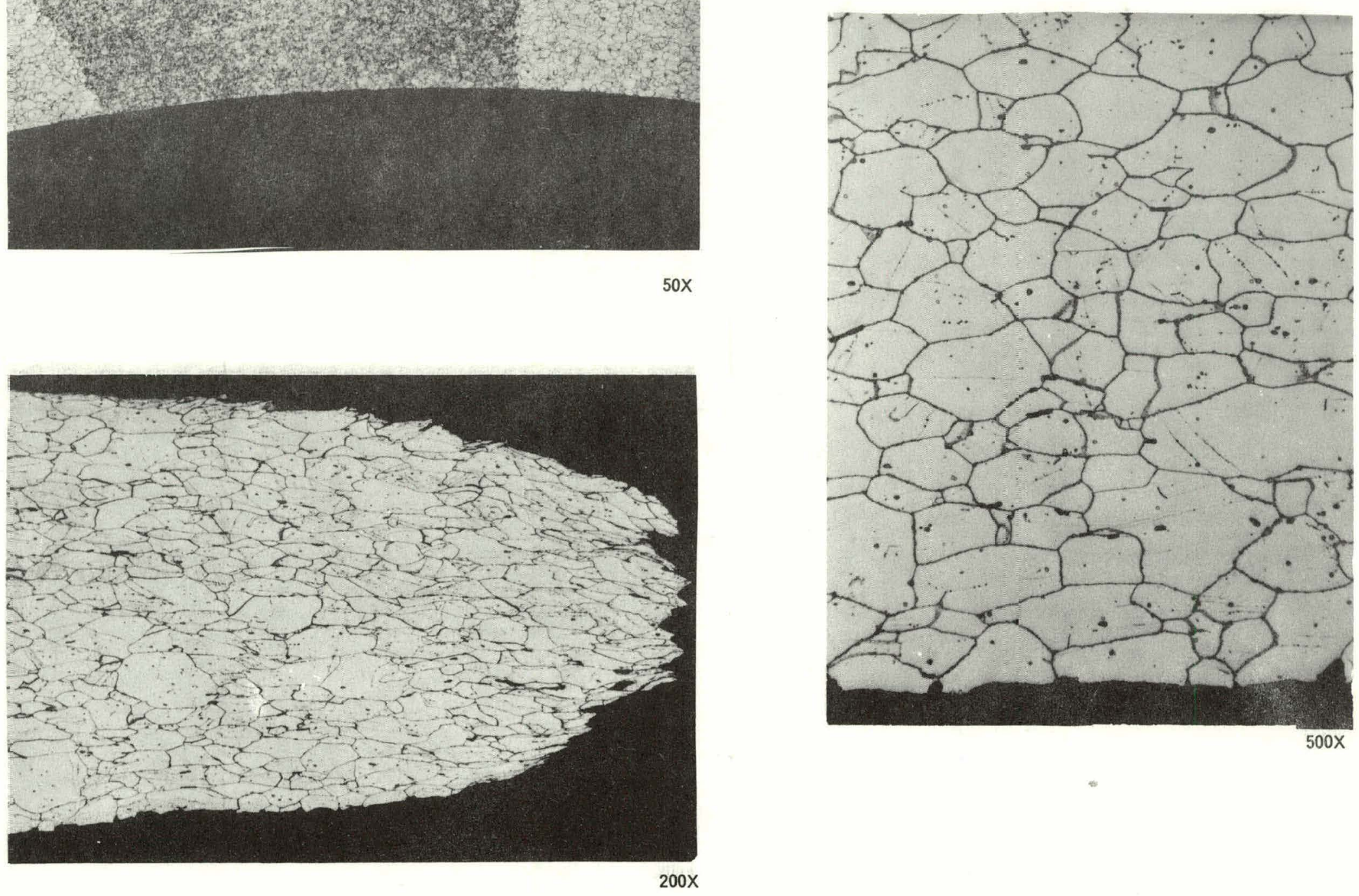

Figure 5-10. Microstructure of Representative Control Specimens, Annealed. Burst Temperature was $900^{\circ} \mathrm{F}$ 


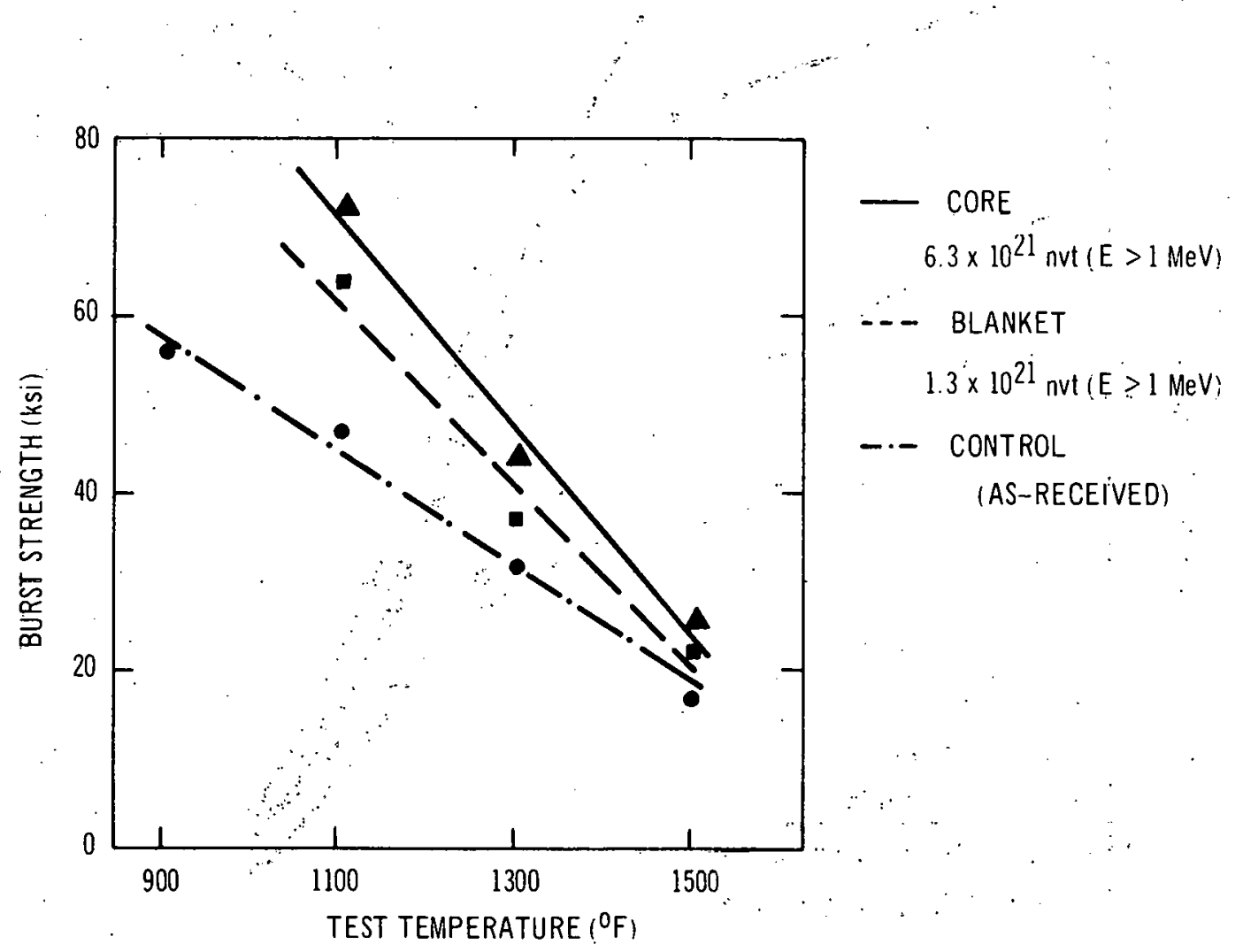

Figure 5-11. Effect of Post-Irradiation Test Temperature on Burst Strength of Type-304 Tubing 


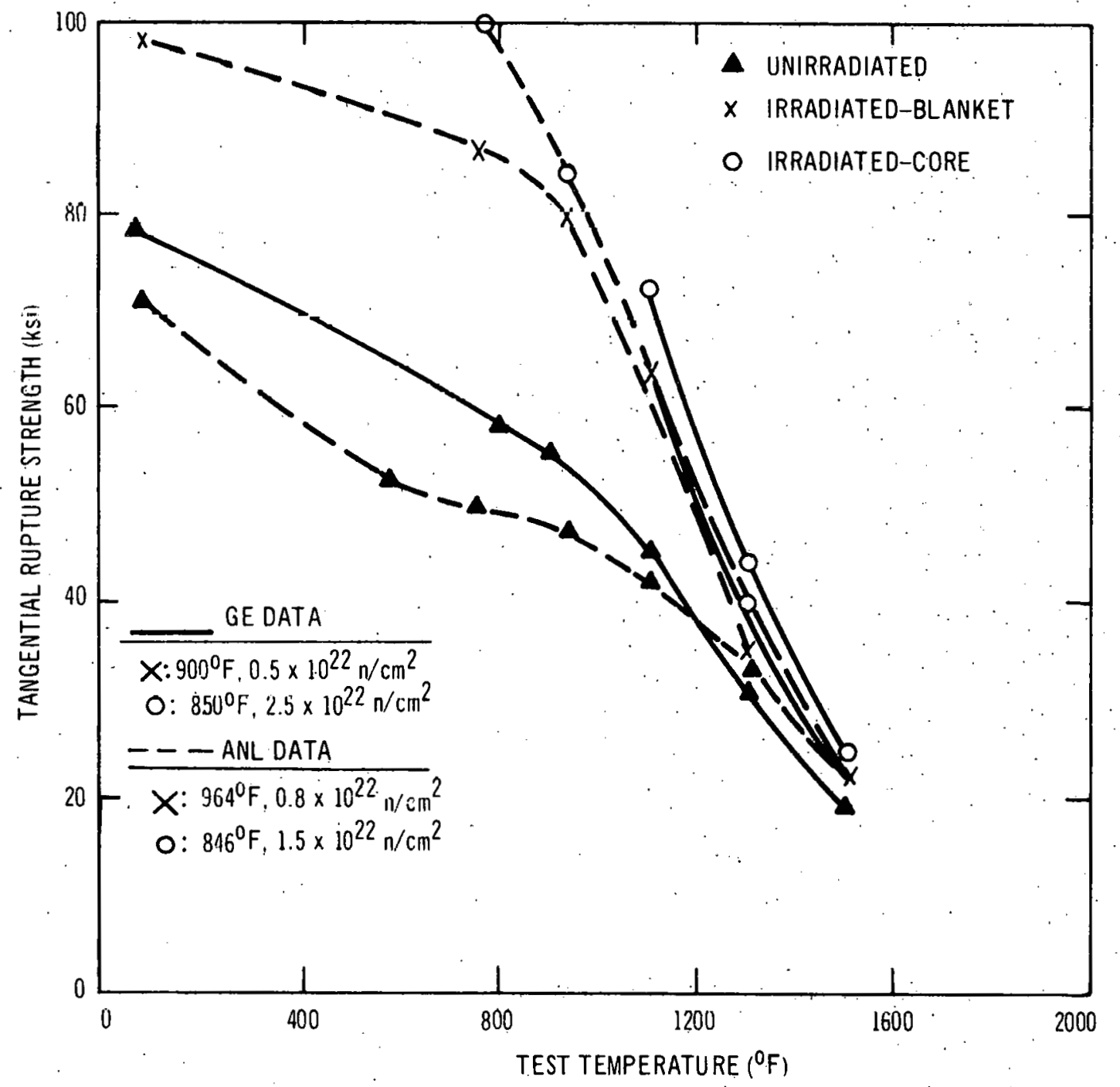

Figure 5-12. Effnct of Irradiation on High I'emperature Rupture Strength of Type-304 Tubing. Comparison with other data. 


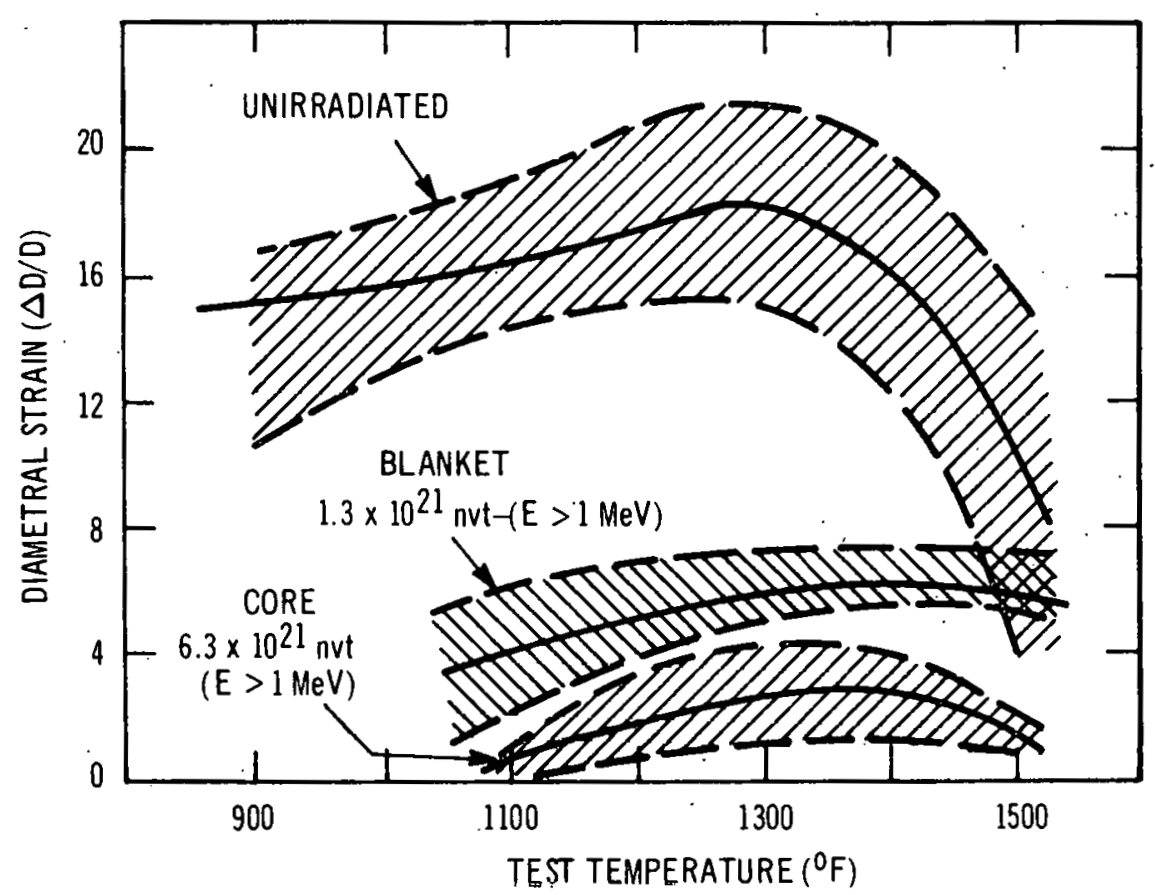

Figure 5-13. Effect of Irradiation on the High-Temperature Ductility of Type-304 Tubing 
TABLE 5-4

BURST DATA ON F2 CAPSULE TUBES-IRRADIATED AND CONTROL

\begin{tabular}{|c|c|c|c|c|c|c|c|c|c|c|c|}
\hline Specimen & & $\begin{array}{c}\text { Test } \\
\text { Temperature }\end{array}$ & & $\begin{array}{l}\text { e to } R u \\
\text { (min) }\end{array}$ & & & $\begin{array}{l}\text { Burst } \\
\text { ssure (p }\end{array}$ & & & $\begin{array}{l}\text { Hoop } \\
\text { trength (ps }\end{array}$ & \\
\hline No. & Condition & $\left({ }^{\circ} \mathbf{F}\right)$ & Core & & Blanket & Core & & Blanket & Core & & Blanket \\
\hline Control 1 & As-received & 900 & & 28.8 & & & 6450 & & & 57,000 & \\
\hline Control 2 & As-received & 900 & & 28.9 & & & 6250 & & & 55,400 & \\
\hline Control 3 & As-received & 900 & & 32.3 & & & 6250 & & & 55,400 & \\
\hline Control Al & Annealed* & 900 & & 32.6 & & & 6450 & & & 57,212 & . \\
\hline Control A2 & Annealed & 900 & & 28.9 & & & 5800 & & & 51,446 & \\
\hline F2P-X & Irradiated & 900 & $>57.9 *$ & & & $>9235$ & & & $>81,800$ & & \\
\hline Control 4 & As-received & 11.00 & & 27.0 & & & 5300 & & & 47,000 & \\
\hline Control 5 & As-received & 1100 & & 27.3 & & & 51.70 & & & 45,900 & \\
\hline Control 6 & As-received & 1100 & & 25.2 & & & 5300 & & & 47,000 & \\
\hline Control A3 & Annealed & 1100 & & 1.9 .0 & & & 4.550 & & & 40,358 & \\
\hline Control A4 & Annealed & 1100 & & 22.0 & & & 4800 & & & 42,576 & \\
\hline Control 44 & As-received & 1100 & & - & & & 51.00 & & & 45,237 & \\
\hline Control 45 & As-received & 1100 & & - & & & 5300 & & & 47,011 & \\
\hline Control 46 & As-received & 1100 & & - & & & 5300 & & & 47,011 & \\
\hline Control 47 & As-received & 1100 & & - & & & 5700 & & & 50,559 & \\
\hline F2A & Irradiated & 1100 & 25.2 & & 38.5 & 8020 & & 7000 & $71,1.00$ & & 62,000 \\
\hline F2B & Irradiated & 1100 & 30.4 & & 42.8 & 8210 & & 70125 & 72,800 & & 62,300 \\
\hline F2Y & Irradiated & 1100 & -43.1 & & 21.5 & 8195 & & 7435 & 72,700 & & 65,900 \\
\hline Control 7 & As-received & 1300 & & 1.6 .7 & & & 3530 & & & 31,300 & \\
\hline Control 8 & As-received & 1.300 & & 17.0 & & & 3440 & & & 30,500 & \\
\hline Control 9 & Asreceived & 1300 & & 18.0 & & & 3700 & & & 32,800 & \\
\hline Control A5 & Annealed & 1300 & & 16.7 & & & 3300 & & & 29,271 & \\
\hline Control A6 & Annealed & 1300 & & 18.2 & & & 3560 & & & 31,557 & \\
\hline F2E & Irradiated & 1300 & 23.3 & & 21..J & 4735 & & 4060 & 42,000 & & 36,000 \\
\hline $\mathrm{F} 2 \mathrm{U}$ & Irradiated & 1300 & 22.1 & & 21.7 & 5020 & & 4125 & 44,500 & & 36,600 \\
\hline $\mathrm{F} 2 \mathrm{Z}$ & Irradiated & 1300 & 20.8 & & 22.7 & 5175 & & 4300 & 45,900 & & 38,100 \\
\hline Control 10 & Asreceived & 1500 & & 9.4 & & & 1820 & & & 16,100 & \\
\hline Control A7 & Annealed & 1500 & & 11.5 & & & 2300 & & & 20,401 & \\
\hline Control A8 & Annealed & 1500 & & 10.9 & & & 2280 & & & 20,224 & \\
\hline Control 48 & As-received & 1500 & & - & & & 2380 & & & 21,106 & \\
\hline Control 49 & Asteceived & 1500 & & - & & & 1950 & & & 17,296 & \\
\hline F2N & Irradiated & 1500 & 10.5 & & 15.2 & 2910 & & 2530 & 25,800 & & 22,400 \\
\hline F2P & Irradiated & 1500 & 16.3 & & 12.2 & 2860 & & $24: 35$ & 25,400 & & 22,000 \\
\hline F2S & Irradiated & 1500 & 11.0 & & 14.2 & 2660 & & $25: 35$ & 23,600 & & 23,000 \\
\hline
\end{tabular}

* 74 days at $1000^{\circ} \mathrm{F}$ in air.

** Specimen did not burst at pressure limit of equipment. 
TABLE 5-5

POST-BURST DIAMETRAL CHANGES IN CONTROL AND IRR ADIATED TYPE-304 TUBING

\begin{tabular}{|c|c|c|c|c|c|c|c|}
\hline $\begin{array}{c}\text { Specimen } \\
\text { No. }\end{array}$ & Position(a) & $\begin{array}{c}\text { Temperature } \\
\left({ }^{\circ} \mathrm{F}\right)\end{array}$ & $\begin{array}{c}\mathbf{D}_{\text {Top }}(\mathbf{b}) \\
\text { (in.) }\end{array}$ & $\begin{array}{c}\mathbf{D}_{\text {Bottom }} \\
\text { (in.) }\end{array}$ & $\begin{array}{c}\mathrm{D}_{\text {Avg }} \\
\text { (in.) }\end{array}$ & $\begin{array}{c}\Delta D \\
\text { (in.) }\end{array}$ & $\begin{array}{c}\Delta \mathrm{D} / \mathrm{D}_{\mathrm{o}} \\
(\%)\end{array}$ \\
\hline $\begin{array}{c}1 \\
2 \\
3 \\
\Lambda 1 \\
\mathrm{~A} 2\end{array}$ & $\begin{array}{l}\text { Control } \\
\text { Control } \\
\text { Control } \\
\text { Annealed Control } \\
\text { Annealed Control }\end{array}$ & 900 & $\begin{array}{l}0.433 \\
0.438 \\
0.432 \\
0.436 \\
0.433\end{array}$ & $\left.\begin{array}{c}- \\
- \\
- \\
- \\
0.415\end{array}\right\}$ & 0.431 & 0.056 & 14.9 \\
\hline F2A-2 & Core & 1100 & - & 0.380 & & & \\
\hline F2B-2 & Core & 1 & - & 0.376 & 0.377 & 0.002 & 0.5 \\
\hline F2Y-2 & Core & & 0.375 & 0.376 & & & \\
\hline F2A-4 & Blanket & & 0.396 & 0.400 & & & \\
\hline F2B-4 & Blanket & & - & 0.389 & 0.390 & 0.015 & 4.0 \\
\hline F2Y-4 & Blanket & & 0.386 & 0.379 & & & \\
\hline 4 & Control & & 0.447 & 0.431 & & & \\
\hline 5 & Control & & 0.442 & 0.442 & & & \\
\hline 6 & Control & & 0.432 & - & 0.437 & 0.062 & 16.5 \\
\hline A3 & Annealed Control & & 0.428 & - & & & \\
\hline A4 & Annealed Control & $y$ & 0.438 & - & & & \\
\hline$\overline{\mathrm{F} 2 \mathrm{E}-2}$ & Core & 1300 & - & 0.383 & & & \\
\hline F2U-1B & Core & 1 & - & 0.391 & & & \\
\hline F2Z-2 & Core & & 0.388 & 0.379 & 0.385 & 0.010 & 2.7 \\
\hline F2E-4 & Blanket & & 0.397 & 0.406 & & & \\
\hline F2U-4B & Blanket & & 0.394 & - & 0.397 & 0.022 & 5.9 \\
\hline F2Z-4 & Blanket & & 0.394 & 0.39 .2 & & & \\
\hline 7 & Control & & 0.437 & - & & & \\
\hline 8 & Control & & 0.451 & 0.44 .3 & 0.443 & 0.068 & 18.1 \\
\hline 9 & Control & & 0.442 & 0.456 & & & \\
\hline A5 & Annealed Control & & 0.440 & $\ldots$. & & & \\
\hline A6 & Annealed Control & $\downarrow$ & 0.431 & - & & & \\
\hline F2N-2 & Care & 1500 & - & 0.378 & & & \\
\hline F2P-2 & Core & & 0.380 & 0.380 & 0.380 & 0.005 & 1.3 \\
\hline F2S-2 & Core & & 0.378 & 0.383 & & & \\
\hline F2N-4 & Blanket & & 0.389 & 0.400 & & & \\
\hline F2P-4 & Blanket & & 0.395 & 0.395 & 0.397 & 0.022 & 5.9 \\
\hline F2S-4 & Blanket & & 0.402 & 0.402 & & & \\
\hline 10 & Control & & 0.434 & - & 0.414 & 0.039 & 10.4 \\
\hline A7 & Annealed Conntrol & & 0.400 & 0.425 & & & \\
\hline A8 & Annealed Control & & 0.412 & 0.390 & & & \\
\hline
\end{tabular}

(a) Core Oluence was $2.5 \times 10^{22}$ total $\mathrm{n} / \mathrm{cm}^{2}$.

Blanket fluence was $0.5 \times 10^{22}$ total $\mathrm{n} / \mathrm{cm}^{2}$.

(b) Diametral measurements were made above and below the fracture region, at a point $1 / 2$-inch from the crack tip. 
perhaps significant, in this regard, that no substantial radiation damage recovery could be detected in these lests, although all specimens were held at the test temperature for 30 minutes prior to the application of pressure.

The bulk of the fast flux radiation damage work to date is restricted to a narrow band, roughly encompassing an exposure level of $10^{21}$ to $10^{22}$ nvt $(E \geqslant 1 \mathrm{MeV})$, but is sufficient to indicate trends in the effect of accumulated fast neutron irradiation on the strength of Type-304 stainless steel. This effect is shown graphically in Figure 5-14. The three curves represent data collected at the three given post-irradiation test temperatures. The reduction in slope of the curves with increasing test temperature is further evidence of the trend toward recovery.

\subsection{TENSILE EVALUATION}

The irradiated tensile coupons described in subsection 4.2 were uniaxially tested on a universal testing manhine at temperatures from 900 to $1500^{\circ} \mathrm{F}$ at strain rates from $0.0002 \mathrm{inch} / \mathrm{inch}-\mathrm{min}$ to $0.112 \mathrm{inch} /$ inch-min. The tensile results are included in Table 5-6 for the five austenitic stainless stecls in both pre-irradiation conditions, annealed at $1800^{\circ} \mathrm{F}$ for 15 minutes, and annealed at $1800^{\circ} \mathrm{F}$ for 15 minutes plus $1650^{\circ} \mathrm{F}$ for 24 hours. Tensile tests were generally performed in duplicate, subsequent to a 15-minute soak at temperature. The data are graphically presented in Figures 5-1,5 to 5-26.

\subsubsection{Propertles of Ailoys in the Mill- Annealed Condition}

Within the fluence range investigated $\left(1.3-6.3 \times 10^{21}\right.$ $\mathrm{n} / \mathrm{cm}^{2} ; \mathrm{En} \geqslant 1 \mathrm{MeV}$ ), irradiation-induced strengthening, measured by $0.2 \%$ offset yield strength, increases from a low of $40 \%$ (Type 321) to as high as 147\% (Type 304) (Figure 5-15). Type 304, showed the greatest amount of strengthening at elevated temperature followed, in decreasing order, by Types $316,321,347$, and Incoloy- 800 .

The degree of strengthening is reduced with increasing test temperatures, with full recovery of unirradiated propertics at $1500 \mathrm{w} 1600^{\circ} \mathrm{F}$ (Figures 5-17 through 5-20). An anomalous behavior was observed with Incoloy -800 (Figure 5-21).

Irradiation-induced embrittlement, monitored by pirrcent reduction in total tensile strain, is similar for all candidate cladding alloys (Figure 5-16). The percentage loss in ductility ranges from 70 to $83 \%$ at the lower fluence, to 82 to $98 \%$ at $6.7 \times 10^{21} \mathrm{n} / \mathrm{cm}^{2}$ (En $>1 \mathrm{MeV}$ ). (Irradiation embrittlement of $100 \%$ indicates nil ductility.)

All alloys showed a general loss in post-irradiation ductility with increasing test temperature (Figures 5-17 through 5-21), while comparable data for unirradiated materials generally increase over the temperature range of 900 to $1500^{\circ} \mathrm{F}$. Note that while recovery of yield stress was obtained at test temperatures of 1500 to $1600^{\circ} \mathrm{F}$, no such restoration of ductility occurred.
Reducing the strain raltes produces a corresponding re:duction in total tensile strain and yield strengths of these irradiated alloys (Figures 5-22 through 5-26). Unirradiated material shows this general behavior at strain rates below $0.02 \mathrm{~min}^{-1}$. For the limited strain rate range investigated on irradiated alloys $\left(0.02\right.$ to $\left.0.0002 \mathrm{~min}^{-1}\right)$, Type $316 \mathrm{~L}$ was least sensitive to strain rate effects within experimental error. The response of ductility to strain-rate changes was similar for Types 304, 321, 347, and Incoloy-800. Types 304 and $316 \mathrm{~L}$ indicated higher ductilities than the other candidate alloys, but the differences are not statistically supported at present.

Both optical and electron metallographic techniques have been uned to rlucidate diffurences observed in the mechanical properties of Type-304 tensile specimens irradiated in these capsules. Two tensile specimens, tested at $1300^{\circ} \mathrm{F}$, were selected for rxamination. Both wcre millanuealed $\left(1800^{\circ} \mathrm{F}\right.$ for $\left.15 \mathrm{~min}\right)$ prior to irradiation but tested at different strain ratcs $\left(0.02\right.$ and 0.0002 min $\left.^{-1}\right)$. The examination showed that incipient cracking occurred with the tensile specimen tested at $0.002 \mathrm{~min}^{-1}$ (Figure 5-27a). Both surface and internal grain-boundary cracking was observed throughout the gage section as far away from the fracture surface as 0.4 inch. The failure was intergranular, and it appeared that two opposite surface cracks, located near each other, converged, causing fracture. The general structure was sensitized, with no grain growth anywhere along the sumple. The specimen teoted at 0.02 unin $^{-1}$ (Figure 5-27b) also showed edge cracking at grain boundaries, as well as internal triple-point cracking which was localized near the failure. Again, no grain growth was observed, and the structure was sensitized.

These obervations are consistent with the expected deformation behavior of this material at comparable strain rates. As shown in Figure 5-28, at $0.02 \mathrm{~min}^{-1}$ the stress increases beyond plastic yielding until failure occurs. However, at $0.0002 \mathrm{~min}^{-1}$ the yield stress and ultimate stress coincide; the stress then continuously decreases with strain, until the fracture strain is attained. Time-dependent propagation of these cracks, in effect, reduces the sample's load-bearing capacity, resulting in reduced loads with further deformation. However, the stress at the crack's tip or at the ceduced internal scetion is increasing slowly.

Recent transmission electron microscopy studies at GE (Ref. 10,11) showed evidence of polyhedral cavities in irradiated austenitic stainless steels; these cavities were correlated with measured density changes in these materials. In Figure 5-29 is a transmission electron micrograph from the gage length of a failed tensile coupon of mill-annealed and irradiated Type 304 which shows similar cavities. Also visible in the figure are dislocations which have interacted with the cavities, forming jogs and intersections. There appears to be a slight denudation of cavities near the grain boundary. Other micrographs show dislocations interconnected with cavities. It is believed that the observed 
TABLE 5-6

POST.IRRADIATION TENSILE PROPERTIES OF AUSTENITIC STAINLESS STEEL

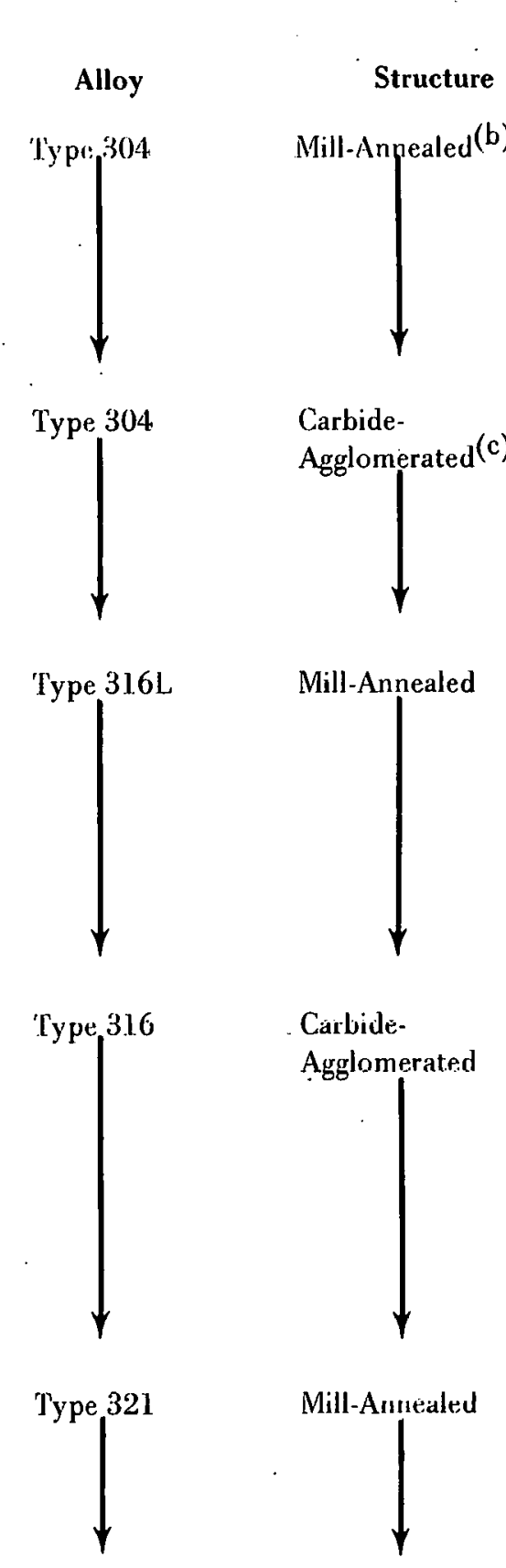

\begin{tabular}{ccl}
$\begin{array}{c}\text { Fluence, } \mathbf{E} \mathbf{1} \mathbf{~ M e V} \\
\left(\mathbf{n} / \mathbf{c m}^{2} \times \mathbf{1 0}^{21}\right)\end{array}$ & Temperature $\left({ }^{\circ} \mathbf{F}\right)$ & $\begin{array}{c}\text { Strain Rate } \\
\left(\mathbf{m i n}^{-1}\right)\end{array}$ \\
& 1300 & \\
1.3 & 1300 & 0.01 \\
1.3 & 1300 & 0.02 \\
6.7 & 1300 & 0.02 \\
6.2 & 1300 & 0.0002 \\
6.7 & 1100 & 0.02 \\
6.7 & 1500 & 0.02 \\
& & \\
0.22 & 1300 & 0.02 \\
0.76 & 1300 & 0.02 \\
2.4 & 1300 & 0.02 \\
3.0 & 1300 & 0.02 \\
2.5 & 1100 & 0.02 \\
3.0 & 1100 & 0.02 \\
& & \\
1.3 & 1300 & 0.02 \\
1.3 & 1300 & 0.02 \\
6.7 & 1300 & 0.02 \\
6.7 & 1300 & 0.02 \\
6.2 & 1300 & 0.0002 \\
6.2 & 1100 & 0.02 \\
6.7 & 1100 & 0.02 \\
6.2 & 1500 & 0.02 \\
& & \\
0.30 & 1300 & 0.02 \\
0.96 & 1300 & 0.02 \\
3.10 & 1300 & 0.01 \\
3.30 & 1300 & 0.02 \\
3.90 & 1300 & 0.01 \\
3.90 & 1300 & 0.02 \\
3.30 & 1.300 & 0.0002 \\
3.10 & 1100 & 0.02 \\
3.30 & 1100 & 0.02 \\
& & \\
1.3 & 1300 & 0.02 \\
1.3 & 1300 & 0.02 \\
6.7 & 1300 & 0.02 \\
6.7 & 1300 & 0.0002 \\
6.7 & 1100 & 0.02 \\
\hline & &
\end{tabular}

Uniform(a)
Strain (\%)
$4.4-6.8$
$7.1-7.8$
$3.3-3.8$
$0.4-0.5$
$3.3-3.4$
$1.2-1.5$
$7.6-9.0$
$7.7-8.0$
$10.7-12.4$
13.4
22.2
15.5

$4.0-7.1$
$4.6-9.4$
$3.1-4.6$
3.8
$0.1-0.4$
$5.4-6.5$
8.8
1.3
$6.1-6.3$
$5.5-6.7$
$1.9-3.7$
5.7
1.6
1.7
$0.4-1.0$
$1.1 .6-20.9$
11.3
$4.6-4.7$
$1.9-2.4$
$1.2-1.5$
$0.2-0.3$
$20-4.4$

Total (a)
Strain $(\%)$
$4.9-7.0$
$1.2 .6-12.9$
$5.2-8.3$
$4.1-5.6$
$4.2-4.4$
$3.6-4.8$

$1.5 .1-15.6$
$10.5-11.0$
$12.1-14.2$
18.0
23.0
1.6 .8

$6.4-9.1$
$7.6-12.3$
$4.4-7.7$
6.4
$5.2-7.3$
$6.1-7.4$
10.9
6.0

$8.9-11.2$
$9.9-11.0$
$2.1-3.9$
7.1
2.1
2.1
$1.2 .5-14.3$
$1.5 .4-22.1$
1.5 .0
$9.1-9.4$
$5.8-7.1$
$1.6-2.5$
$0.2-0.4$
$2.2-5.4$

$\begin{array}{cc}\begin{array}{c}\text { Yield } \\ \text { Stress } \\ \mathbf{( 0 . 2 \% , ~ k s i )}\end{array} & \begin{array}{c}\text { Ultimate } \\ \text { Stress } \\ \mathbf{( k s i )}\end{array} \\ 19.4-26.9 & 34.3-35.8 \\ 27.8-28.4 & 34.3-34.7 \\ 36.0-38.4 & 40.7-41.0 \\ 24.0-27.2 & 24.2-27.2 \\ 54.8-54.9 & 57.1-58.6 \\ 19.3-19.3 & 19.9-20.1 \\ & \\ 25.3-27.8 & 32.6-33.8 \\ 21.4-28.7 & 35.6-37.9 \\ 16.4-16.7 & 26.8-28.6 \\ 16.2 & 26.4 \\ 1.5 .3 & 39.5 \\ 1.7 .5 & 39.2 \\ & \end{array}$

$30.1-39.2$

$22.5-32.0$

$9.9-41.7$

$39.5-44.3$

$32.6-37.5$
$44.1-47.3$

39.7

$25.7-28.3 \quad 26.0-28.3$

$49.4-56.7$

$62.0-28.3$

24.1

24.5

$21.4-27.3 \quad 30.5-36.3$

$38.1-38.7 \quad 43.1-43.4$

$30.7-32.7 \quad 36.7-37.3$

19.0

43.8

29.8

1.5.9- 51.3

18.5

31.2
49.0

41.1

20.9-24.2

5.7

$34.7-35.1$

2.0-34.5

$37.7-38.0$

$33.1-35.4$

21.5-24.3

63.0-68.0 
TABLE 5-6, (Continued)
POST-IRRADIATION TENSILE PROPERTIES OF AUSTENITIC

STAINLESS STEEL

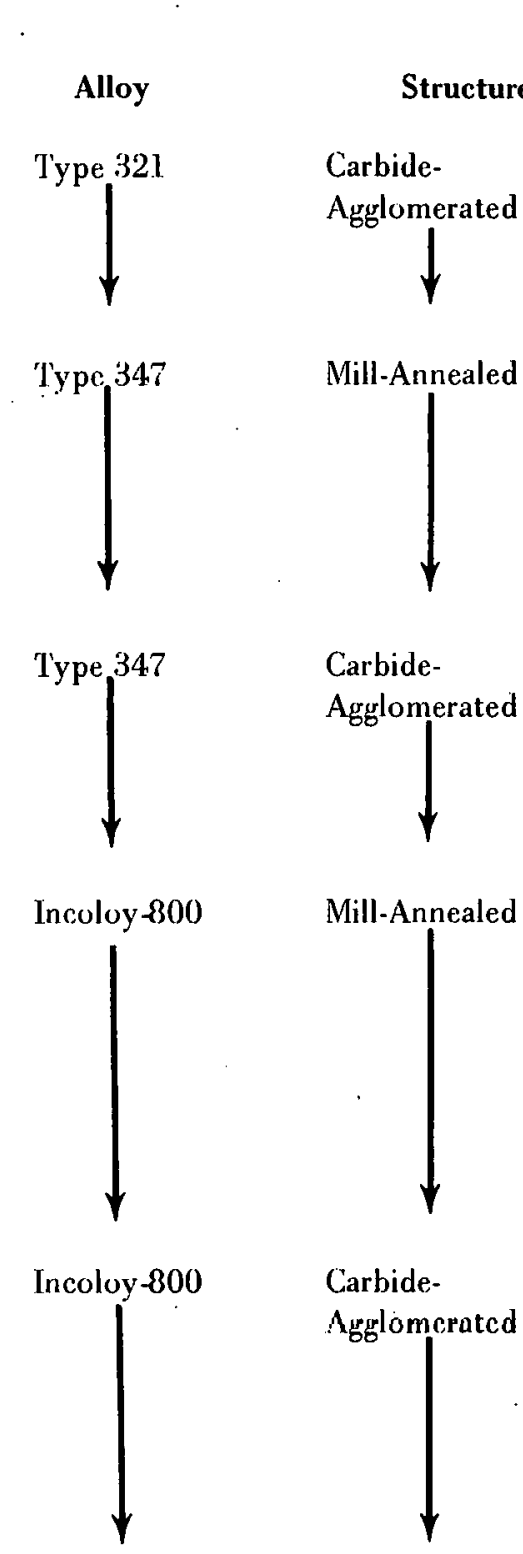

$\begin{gathered}\text { Fluence, } \mathrm{E}>\mathbf{1} \mathbf{M e V} \\ \left(\mathbf{n} / \mathbf{c m}^{2} \times \mathbf{1 0} \mathbf{0}^{\mathbf{1}}\right)\end{gathered}$
0.76
3.0
2.5
2.4
1.3
6.2
6.7
6.2
6.2
6.2

0.22
0.76
3.0
2.5
2.4

1.3
1.3
6.2
6.2
6.7
6.2
6.7
6.7

0.76
3.0
2.4
3.0
3.0
2.5
2.4

$\begin{array}{cl}\text { Temperature }\left({ }^{\circ} \mathbf{F}\right) & \begin{array}{c}\text { Strain Rate } \\ \left(\mathbf{m i n}^{-1}\right)\end{array} \\ 1300 & 0.02 \\ 1300 & 0.02 \\ 1100 & 0.02 \\ 1500 & 0.02 \\ & \\ 1300 & 0.02 \\ 1300 & 0.02 \\ 1300 & 0.01 \\ 1300 & 0.0002 \\ 1100 & 0.02 \\ 1500 & 0.02 \\ & \\ 1300 & 0.02 \\ 1300 & 0.02 \\ 1300 & 0.02 \\ 1100 & 0.02 \\ 1500 & 0.02 \\ & 0.02 \\ 1300 & 0.02 \\ 1300 & 0.02 \\ 1300 & 0.02 \\ 1300 & 0.01 \\ 1300 & 0.0002 \\ 1300 & 0.01 \\ 1100 & 0.01 \\ 1500 & 0.02 \\ 1300 & 0.02 \\ 1800 & 0.0002 \\ 1300 & 0.0002 \\ 1300 & 0.02 \\ 900 & 0.02 \\ 1100 & 0.02 \\ 1500 & \\ & \end{array}$

Uniform (a)
Strain $(\%)$
$6.6-6.9$
$2.2-2.7$
$1.7-1.7$
$2.0-2.4$

$4.0-4.1$
0.7
0.9
$0.5-0.6$
$1.4-1.5$
0.9
$11.2-11.4$
$2.0-8.2$
$8.1-8.6$
$8.1-8.3$
$3.8-4.1$
$3.2-4.5$
$3.0-3.8$
$0.7-0.8$
$0.7-2.7$
$2.0-3.3$
$0.2-0.4$
$2.1-2.2$
$1.1-1.1$
$2.6-3.2$
1.6 .2 .0
$0.4-0.9$
0.5
9.2
$2.4-2.5$
$1.0-1.6$

Total(a)
Strain (\%)
$14.8-1.5 .2$
$5.3-5.8$
$2.6-3.1$
$9.8-1.0 .1$

$6.8-7.3$
1.4
1.0
$0.7-1.1$
$2.2-2.6$
4.3

$26.6-32.2$
$5.0-10.0$
$10.3-11.8$
$9.4-10.5$
$8.9-10.2$

$6.6-8.8$
$4.3-4.9$
$0.8-1.3$
$4.5-5.8$
$2.2-3.9$
$1.6-3.2$
$2.3-2.6$
$3.5-5.4$

$5.3-8.9$
$3.6 \quad 1.4$
$6.3-7.9$
8.2
10.7
$2.7-3.1$
$9.6-10.5$

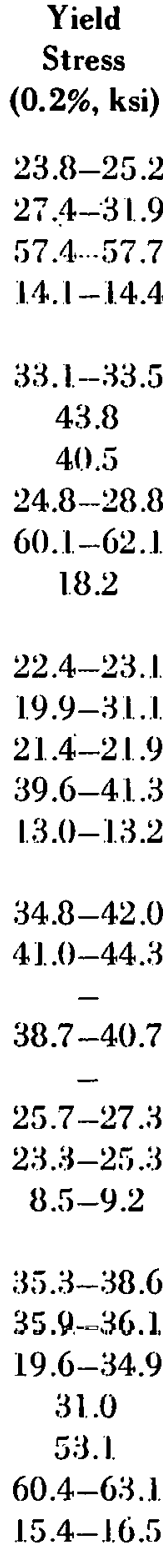

Ultimate (ksi)

$28.9-30.4$ $29.3-34.6$ $15.2-15.6$ $39.2-40.7$ 44.2 $25.8-29.0$ 61. $14-63.4$ 18.8

(a) Original gage length: 1 inch.

(c) Annealed at $1800^{\circ} \mathrm{F}$ for 15 minutes, air quenched: leeal-treated at $1650^{\circ} \mathrm{F}$ fur 24 hivurs, air quetriched. 


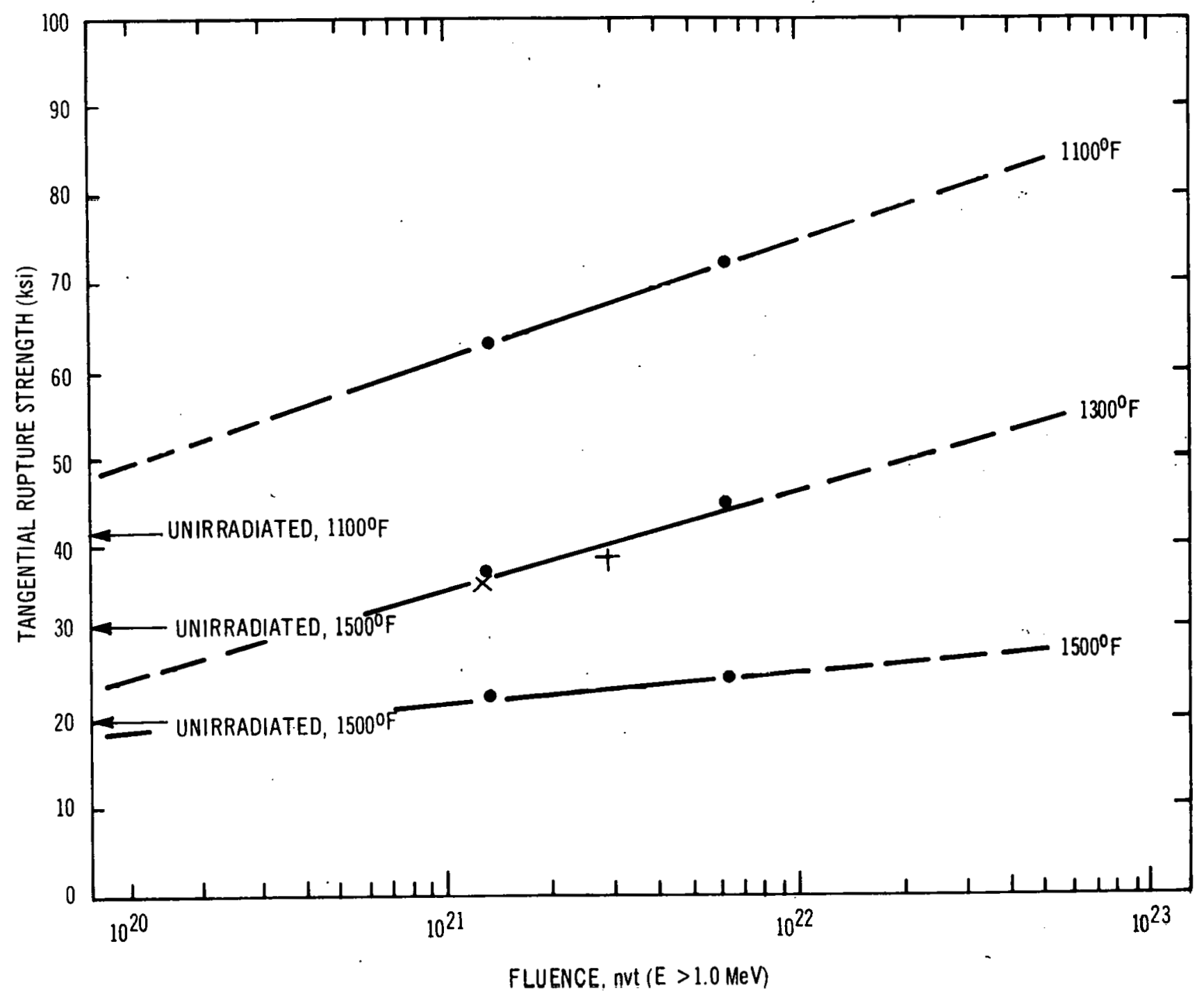

Figure 5-14. Effect of Fluence and Test Temperature on Rupture Strength of Type-304 Tubing 


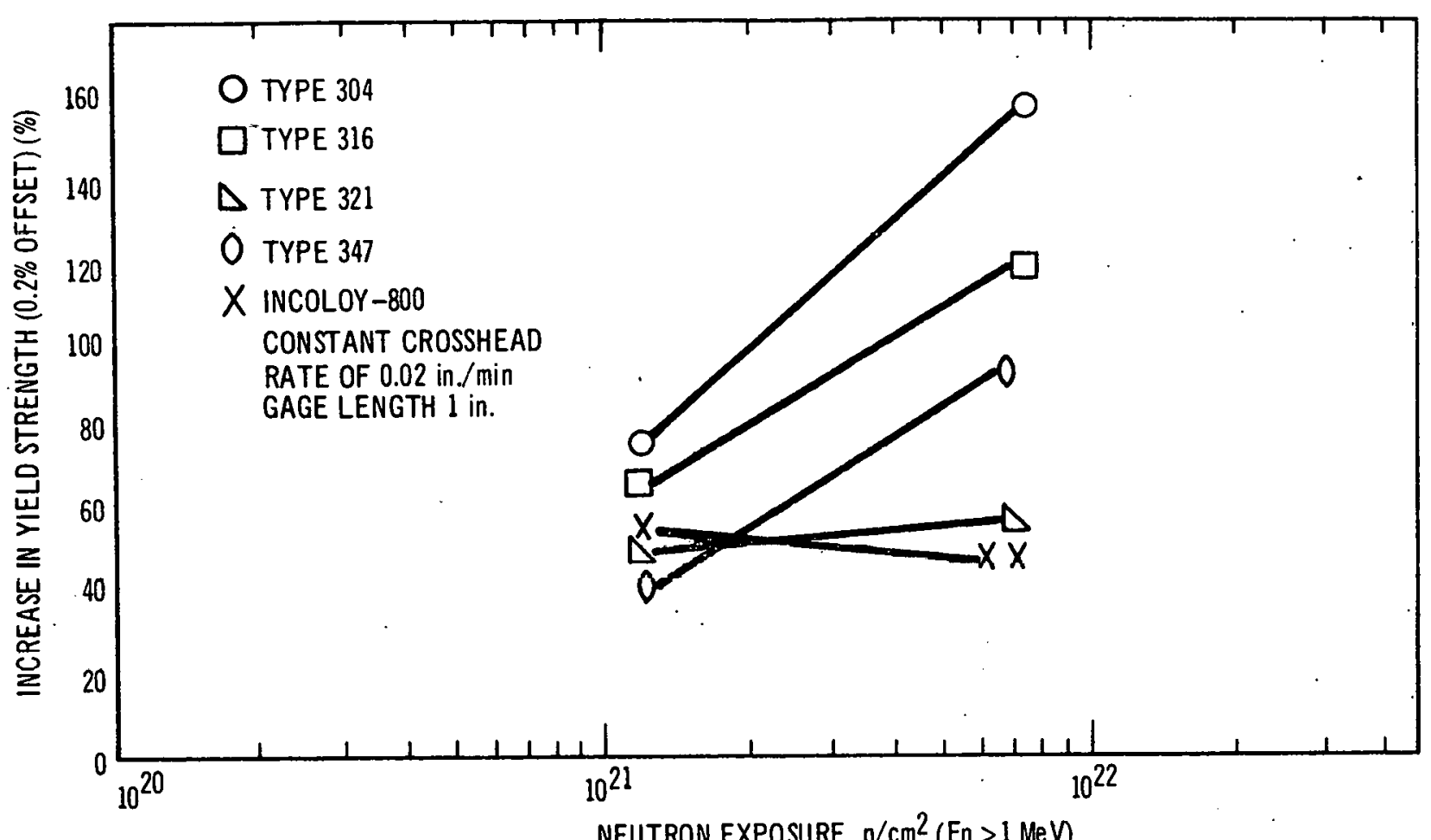

Figure 5-15. Radiation Strengthening of Austenitic Stainless Steel at $1300^{\circ} \mathrm{F}$ versus Fluence

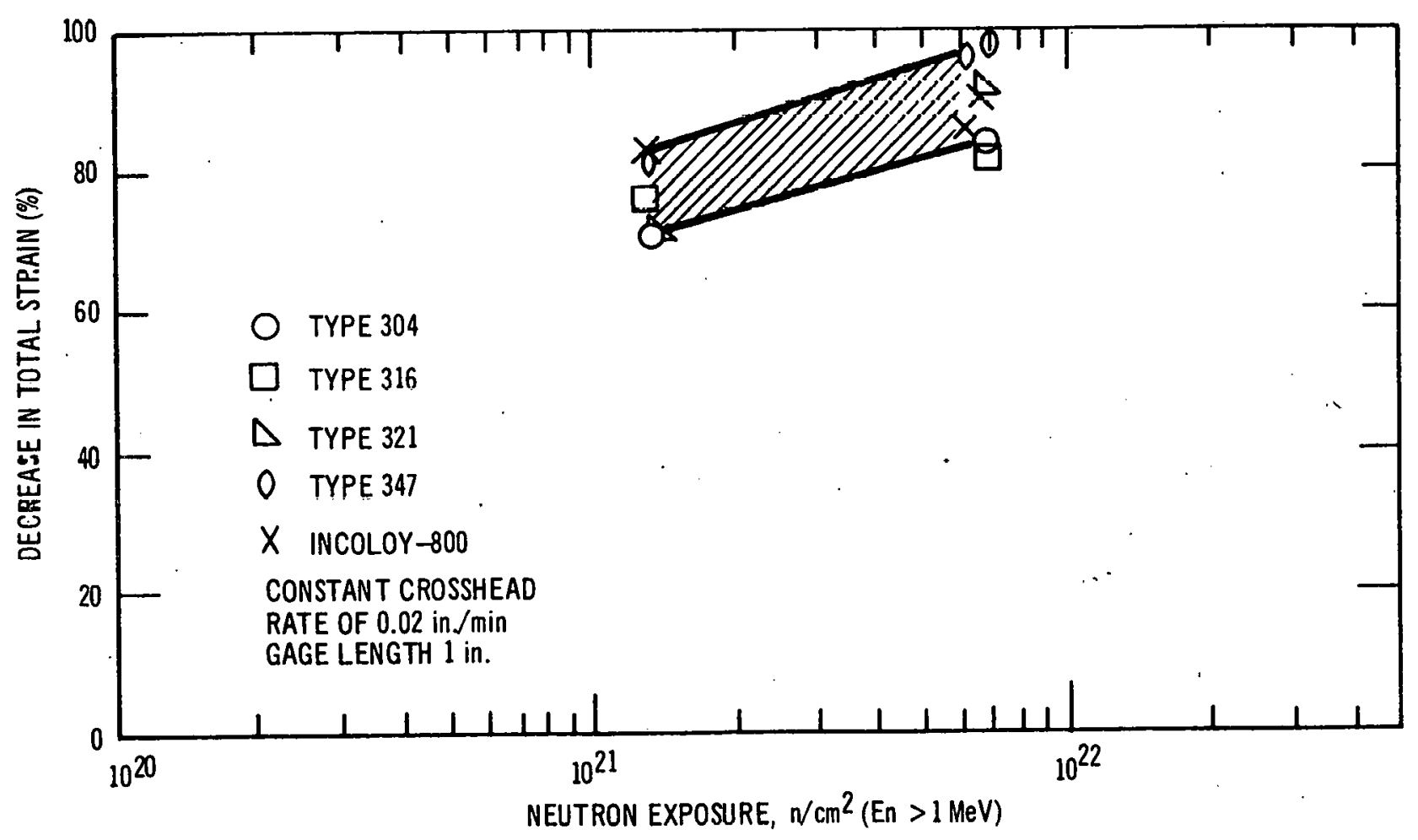

Figure 5-16. Radiation Embrittlement of Austenitic Stainless Steel at $1300^{\circ} \mathrm{F}$ versus Fluence 

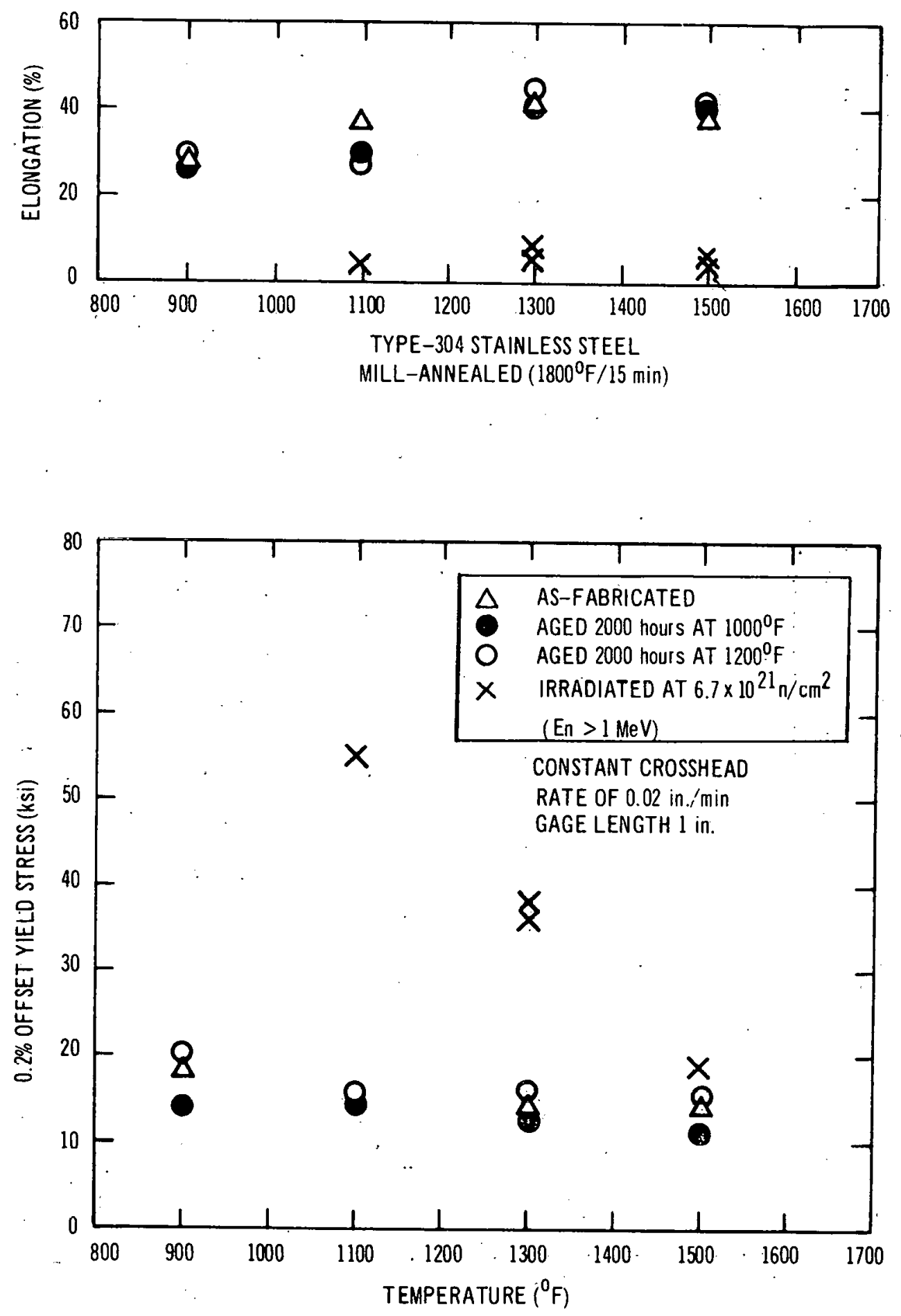

Figure 5-17. Temperature Dependence of Type 304 Tensile Properties 

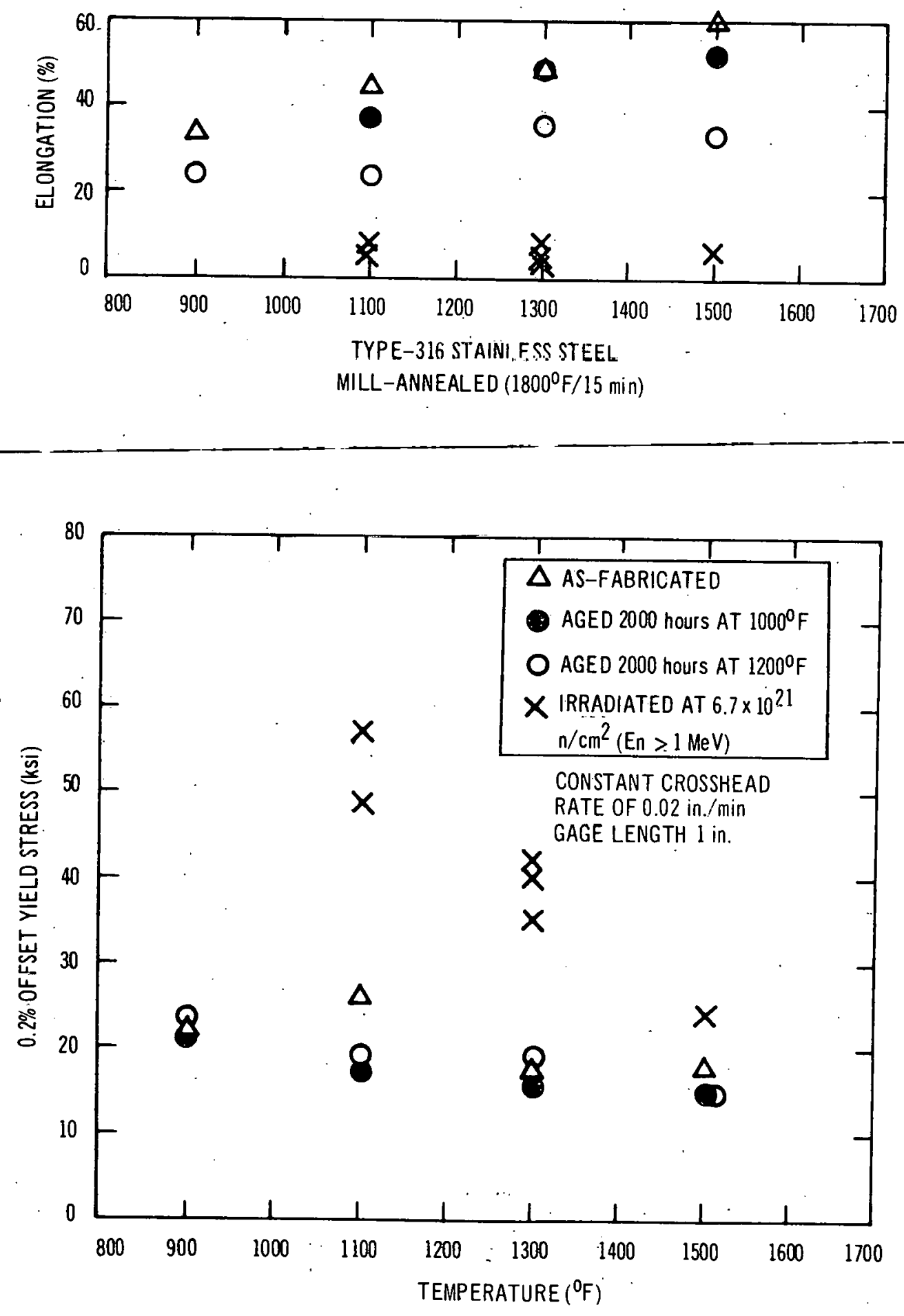

Figure 5-18. Temperature Dependence of Type 316L Tensile Properties 

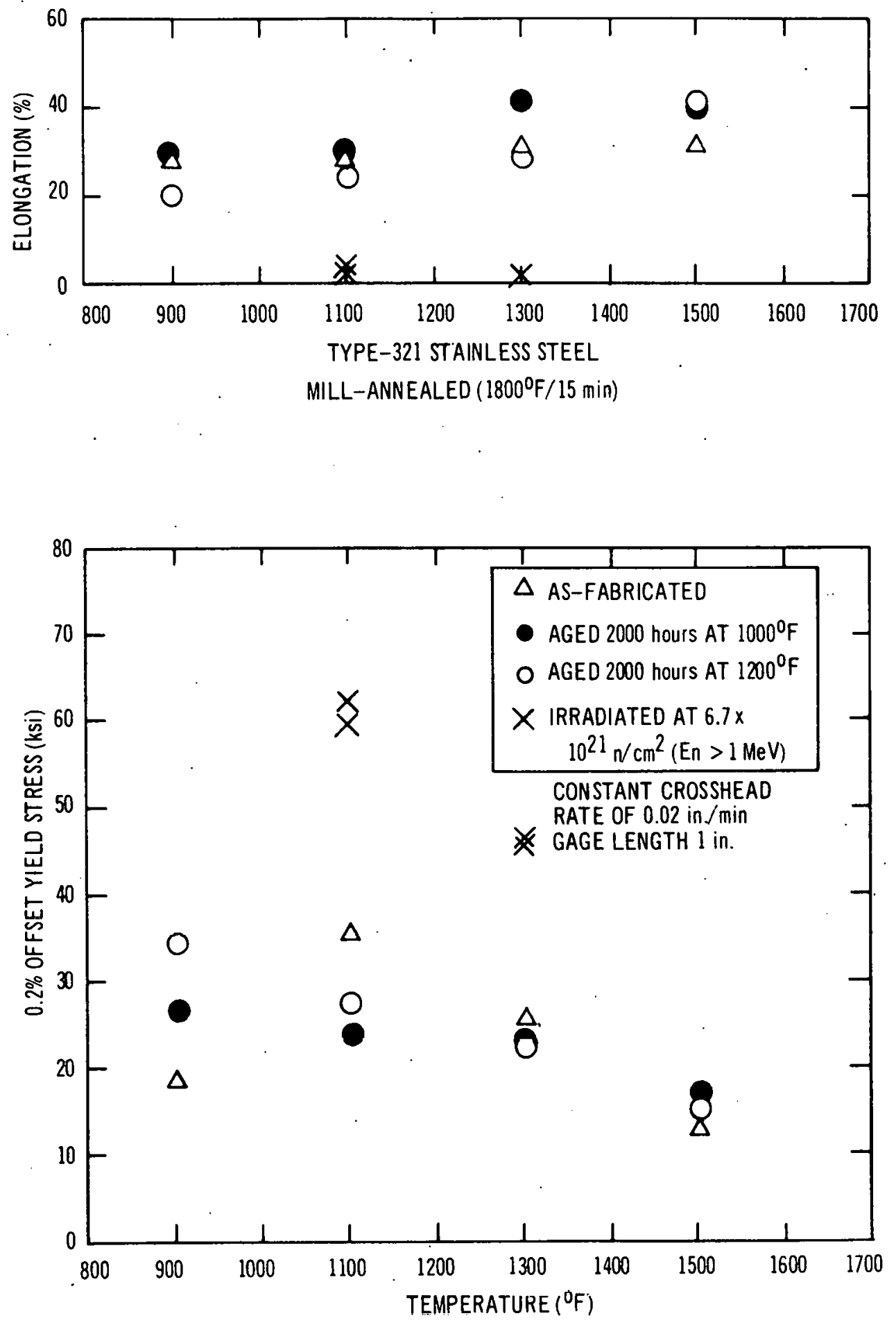

Figure 5-19. Temperaturc Depondonos of Type 321 Tensile. Properties 

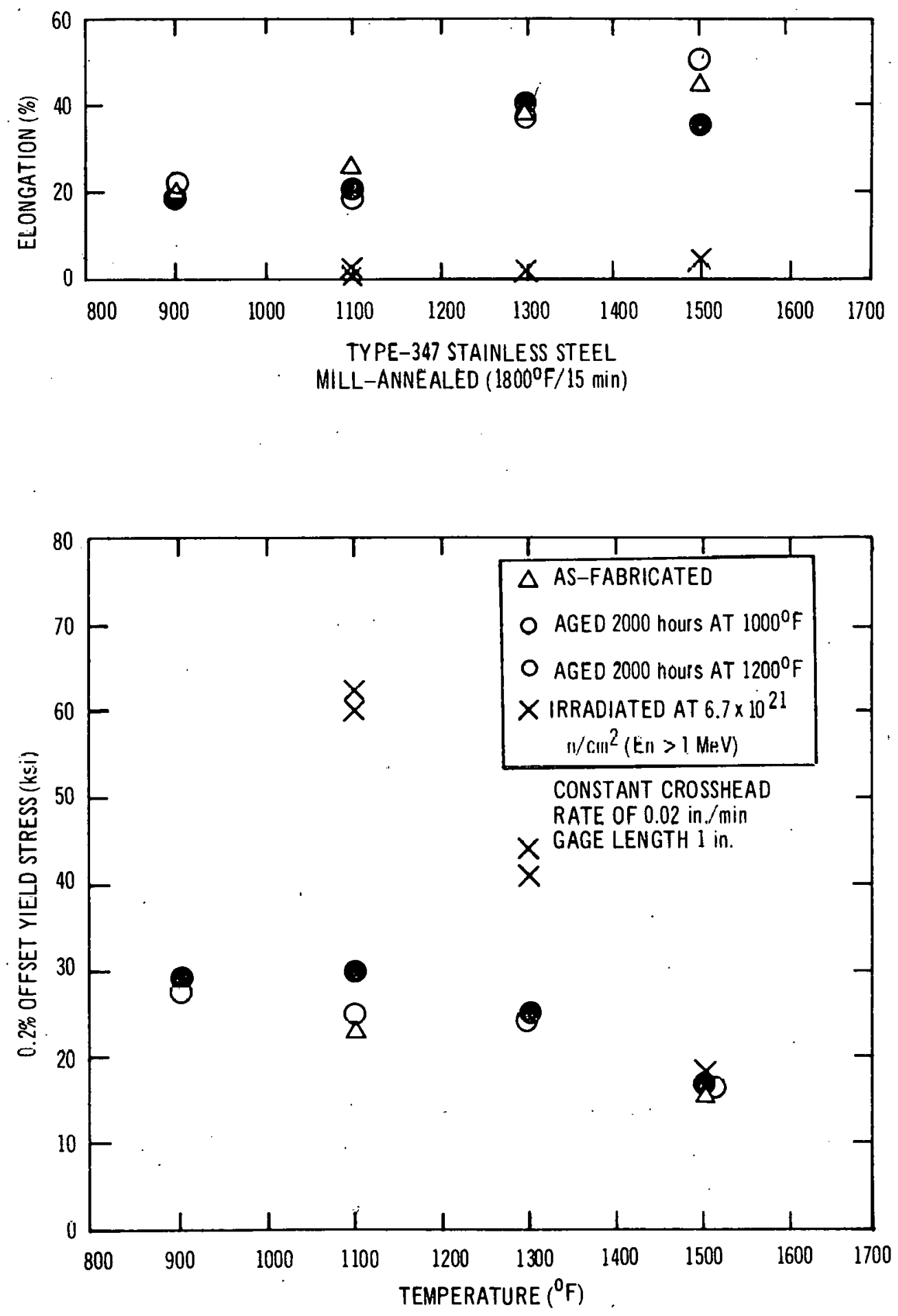

Figure 5-20. Temperature Dependence of Type 347 Tensile Properties 

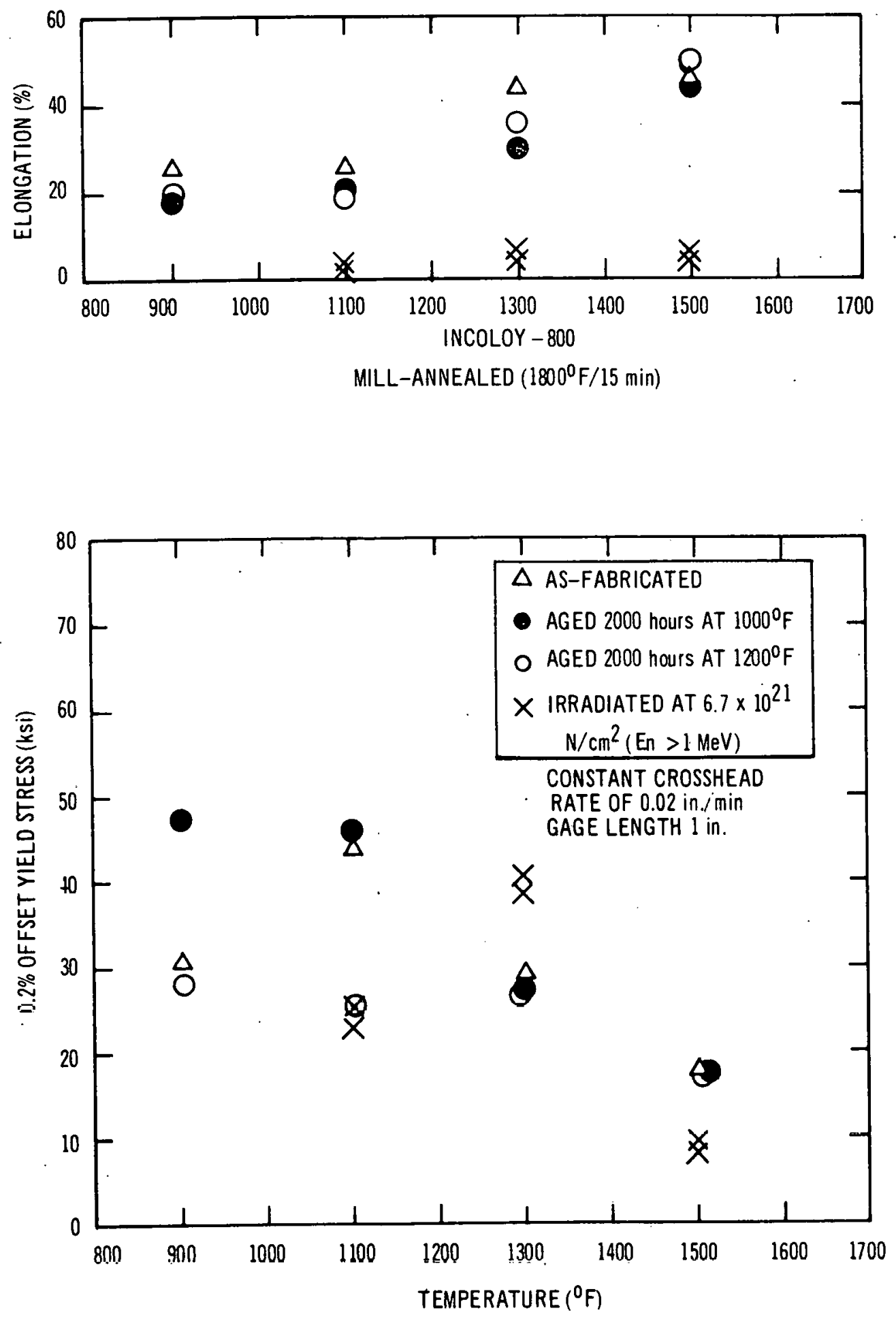

Figure 5-21. Temperature Dependence of Incoloy-800 Tensile Properties 


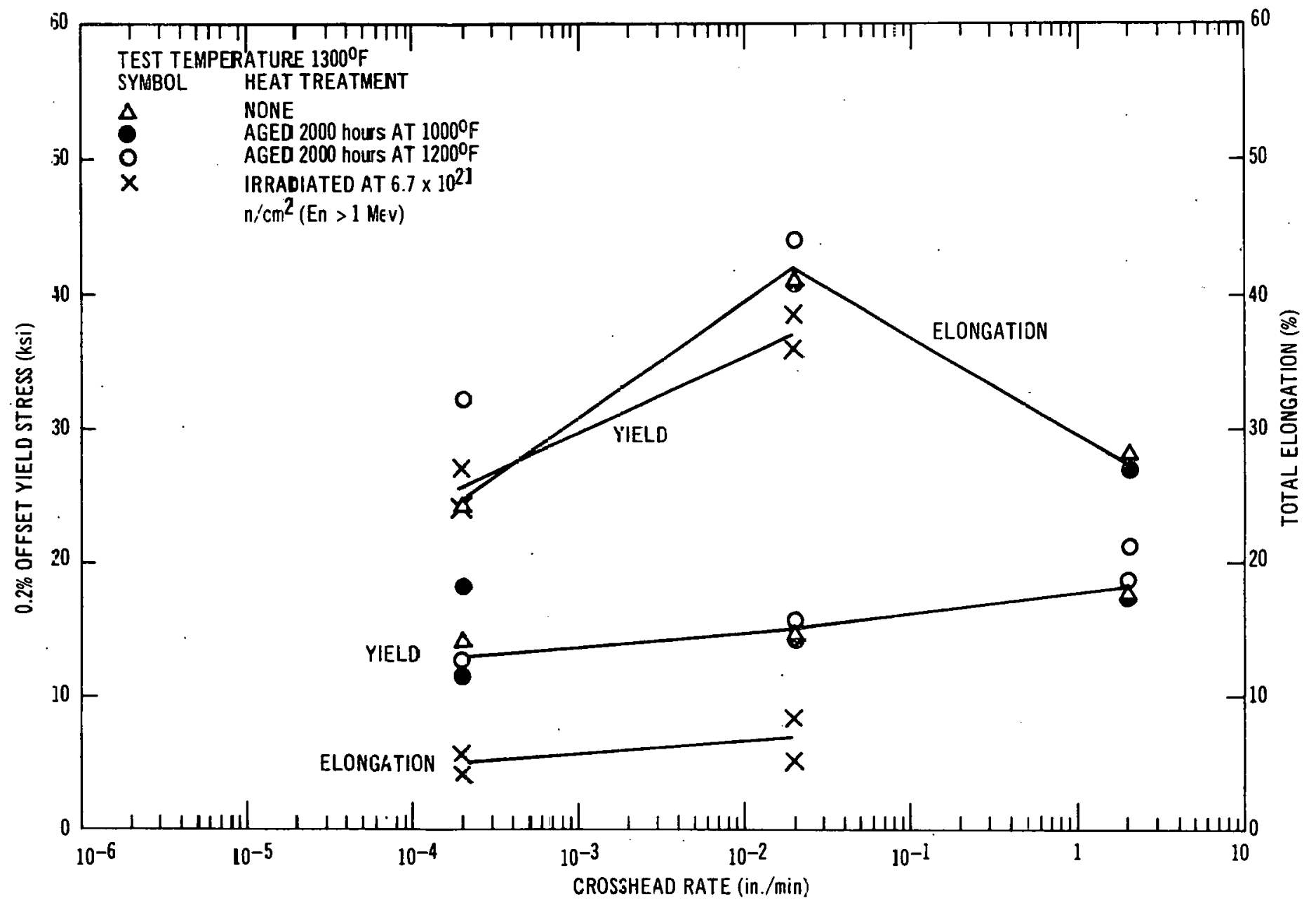

Figure 5-22. Ratz Dependenee of $1300^{\circ} \mathrm{F}$ Tensile Properties for Type 304 


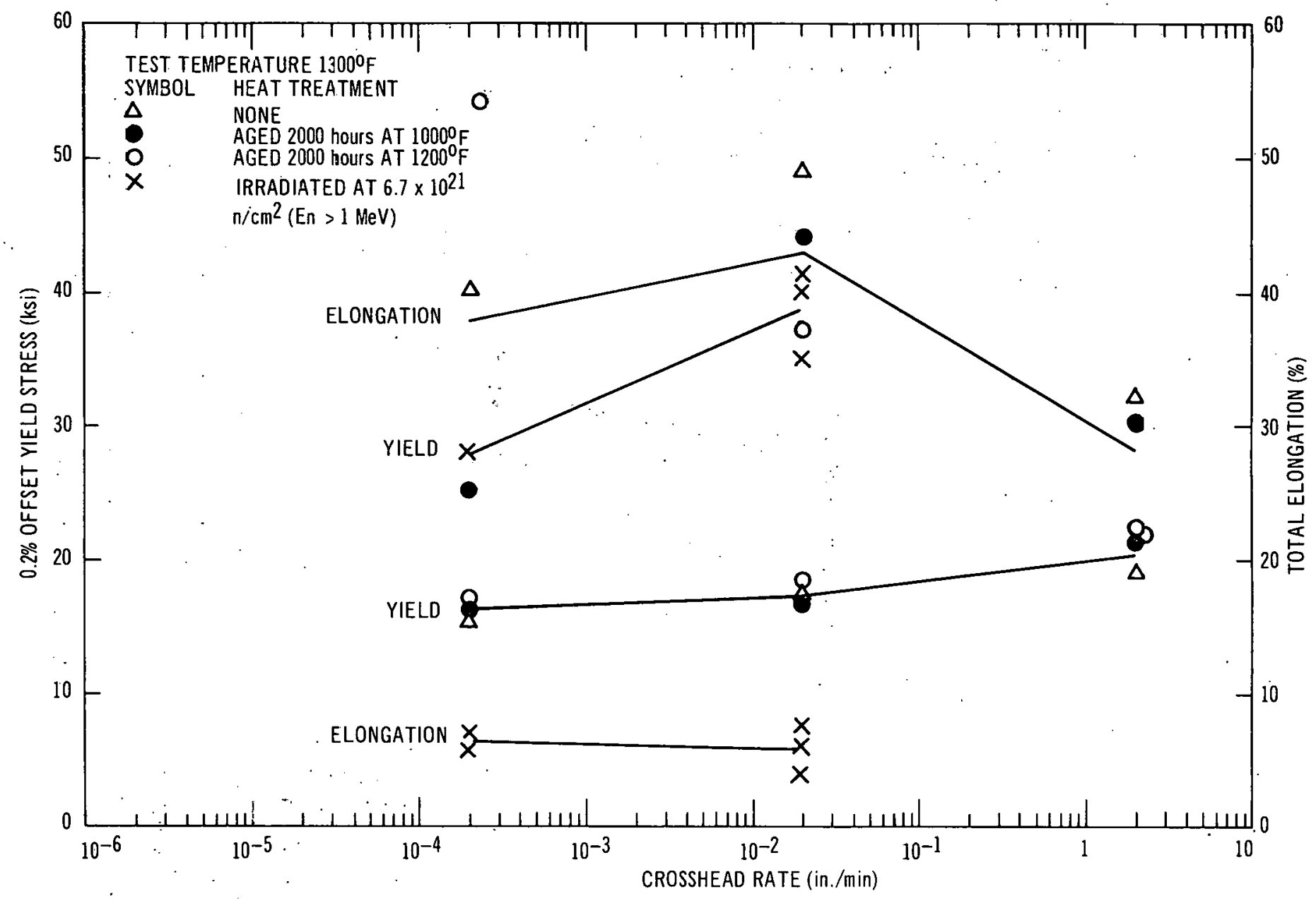

Figure 5-23. Rate Dependence of $1300^{\circ} \mathrm{F}$ Tensile Properties for Type $316 \mathrm{~L}$ 


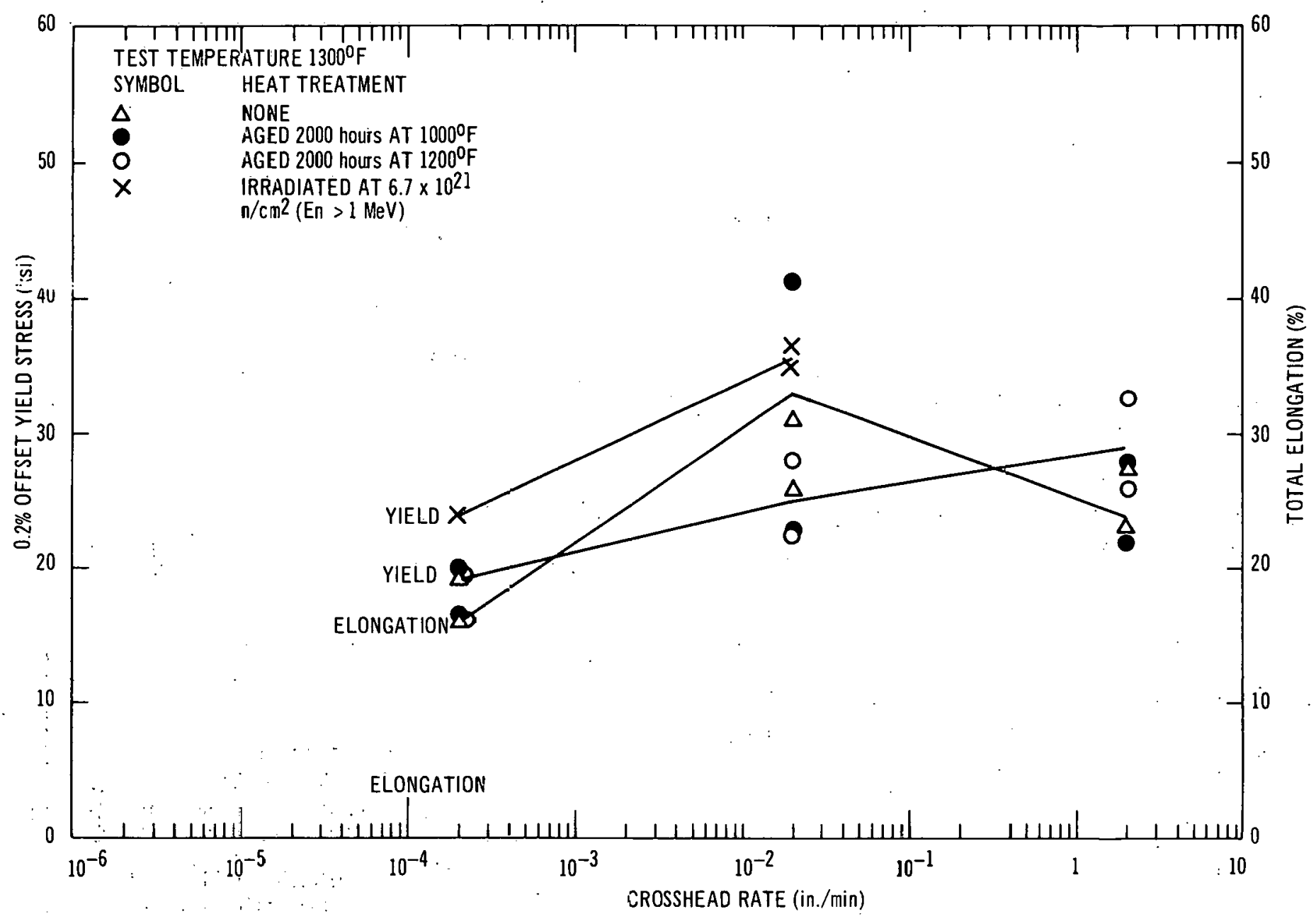

Figure 5-24. Rate Dependence of $1300^{\circ} \mathrm{F}$ Tensile Properties for Type 321 


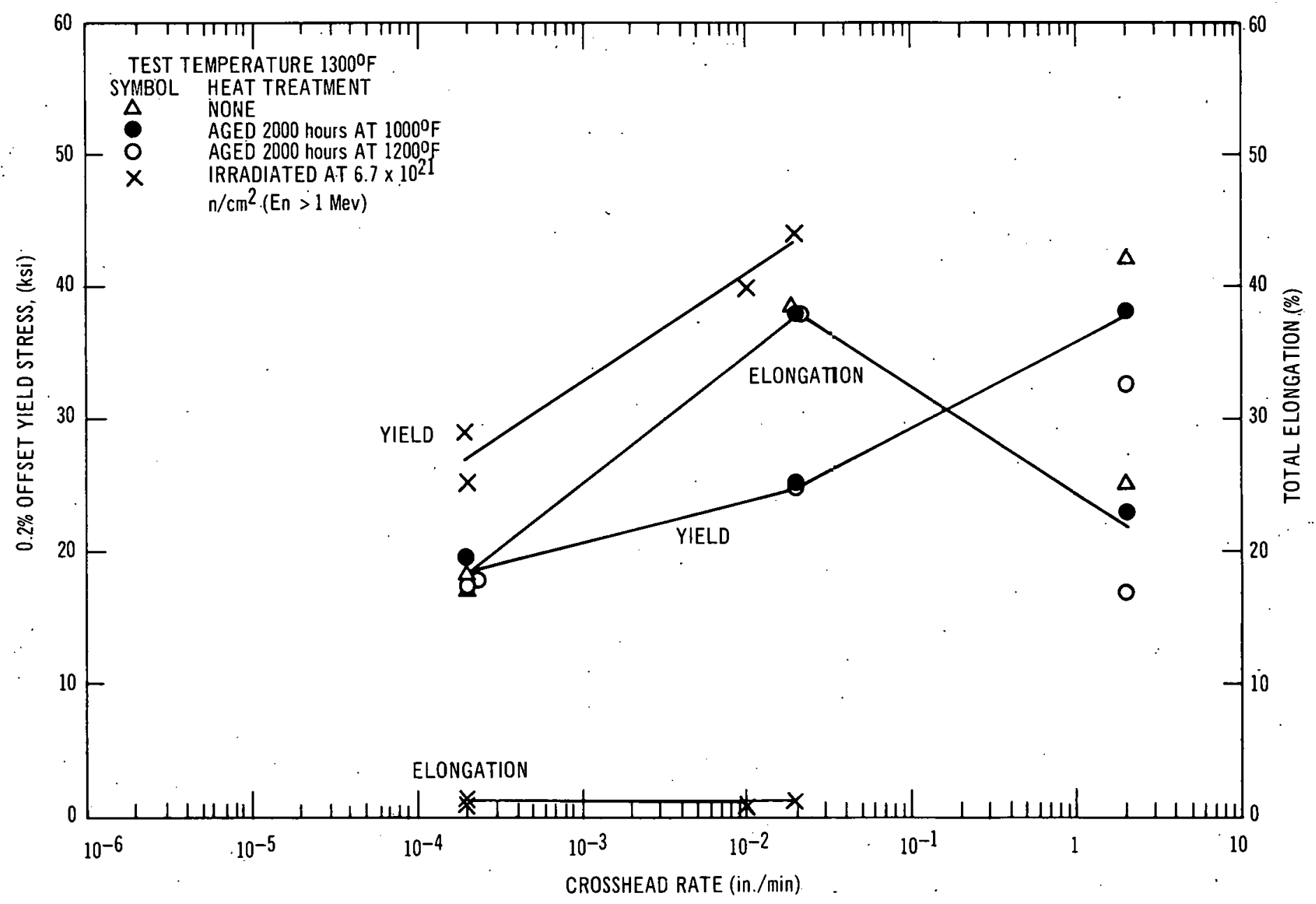




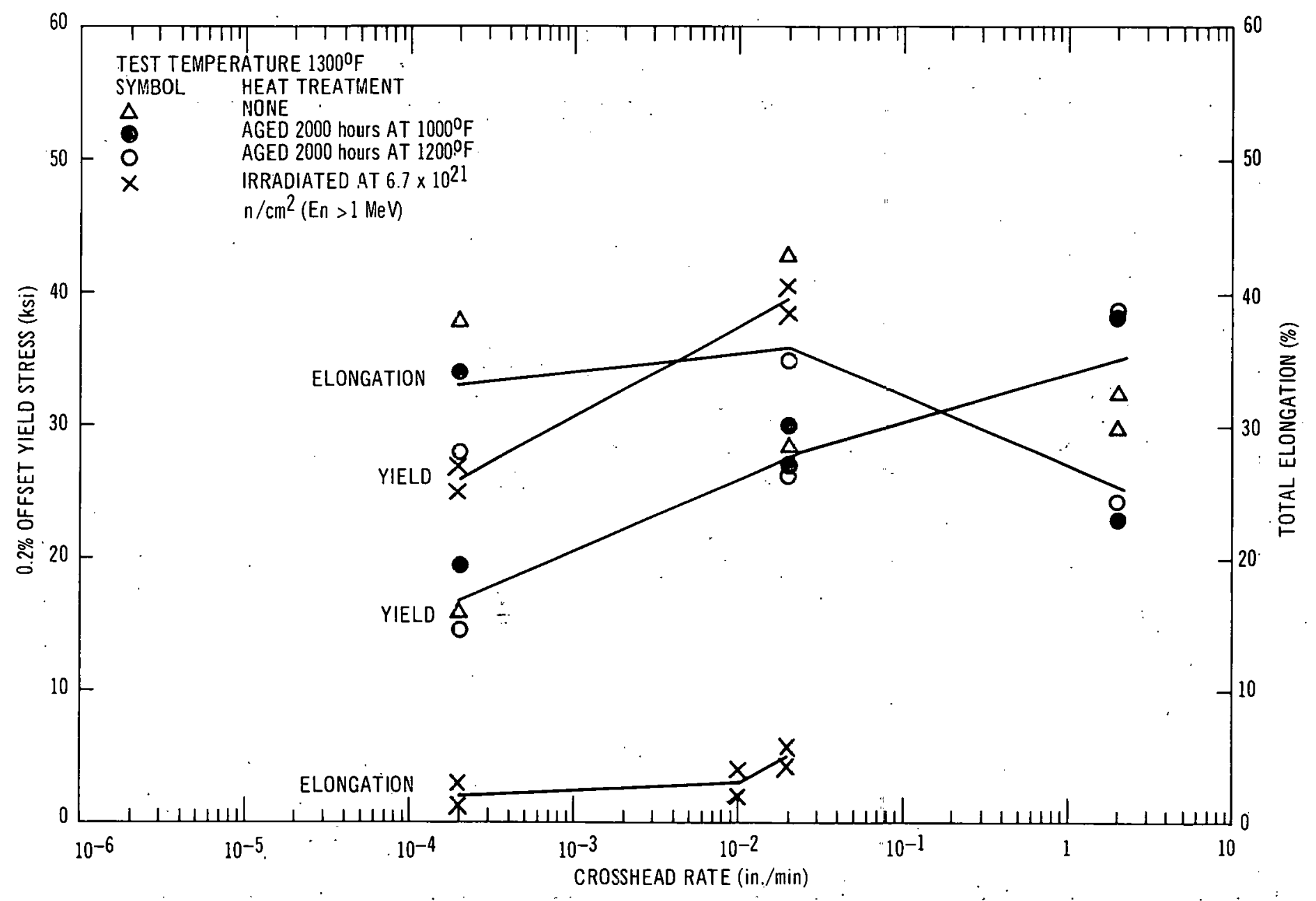

Figure 5-26. Rate Dependence of $1300^{\circ} \mathrm{F}$ Tensile Properties far Incoloy- 800 


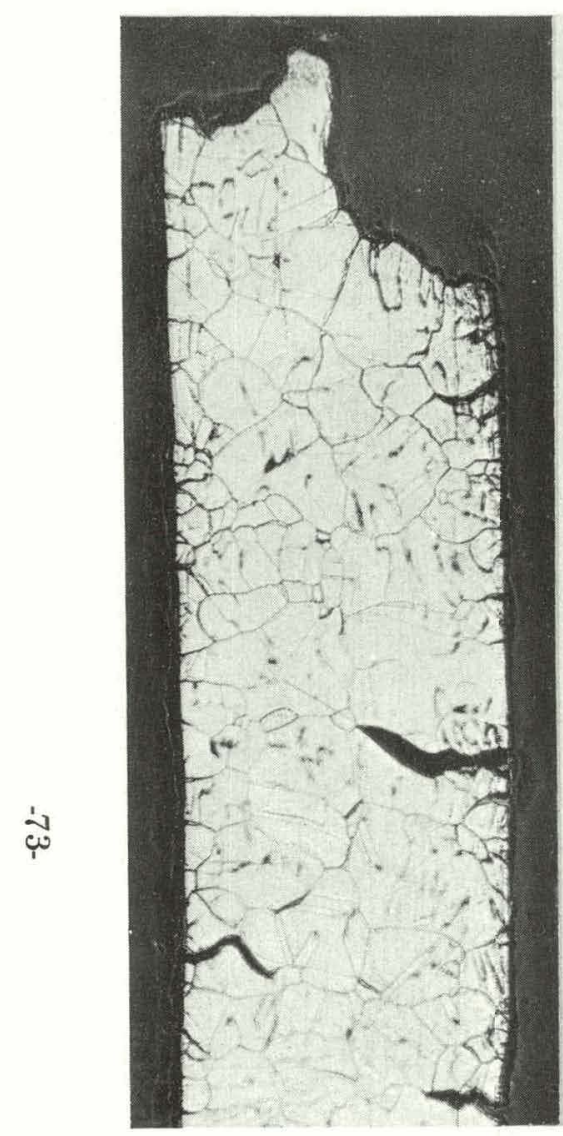

(a)

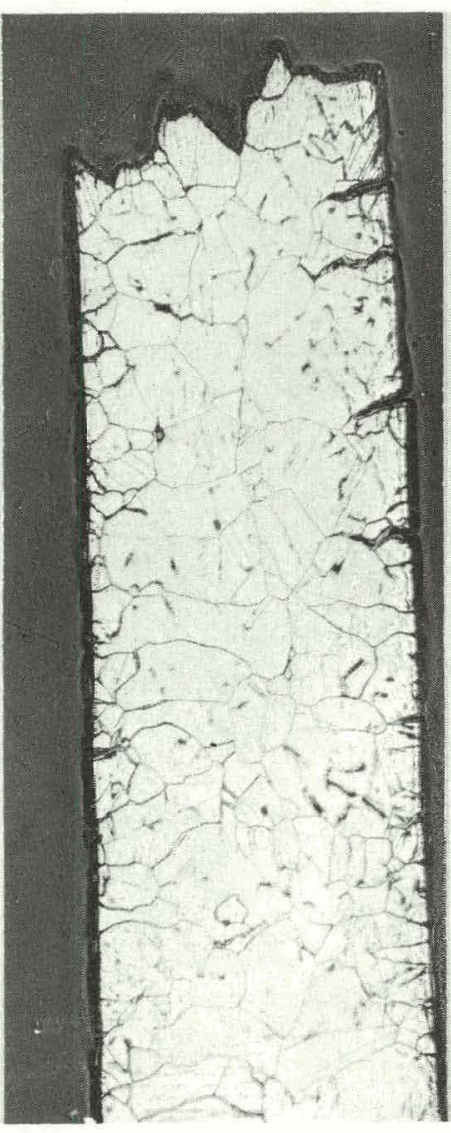

(b)

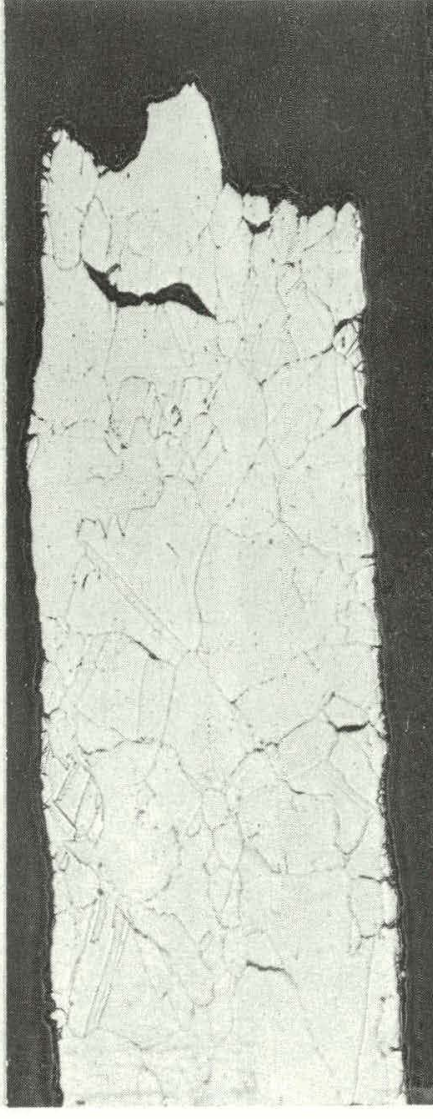

(c)

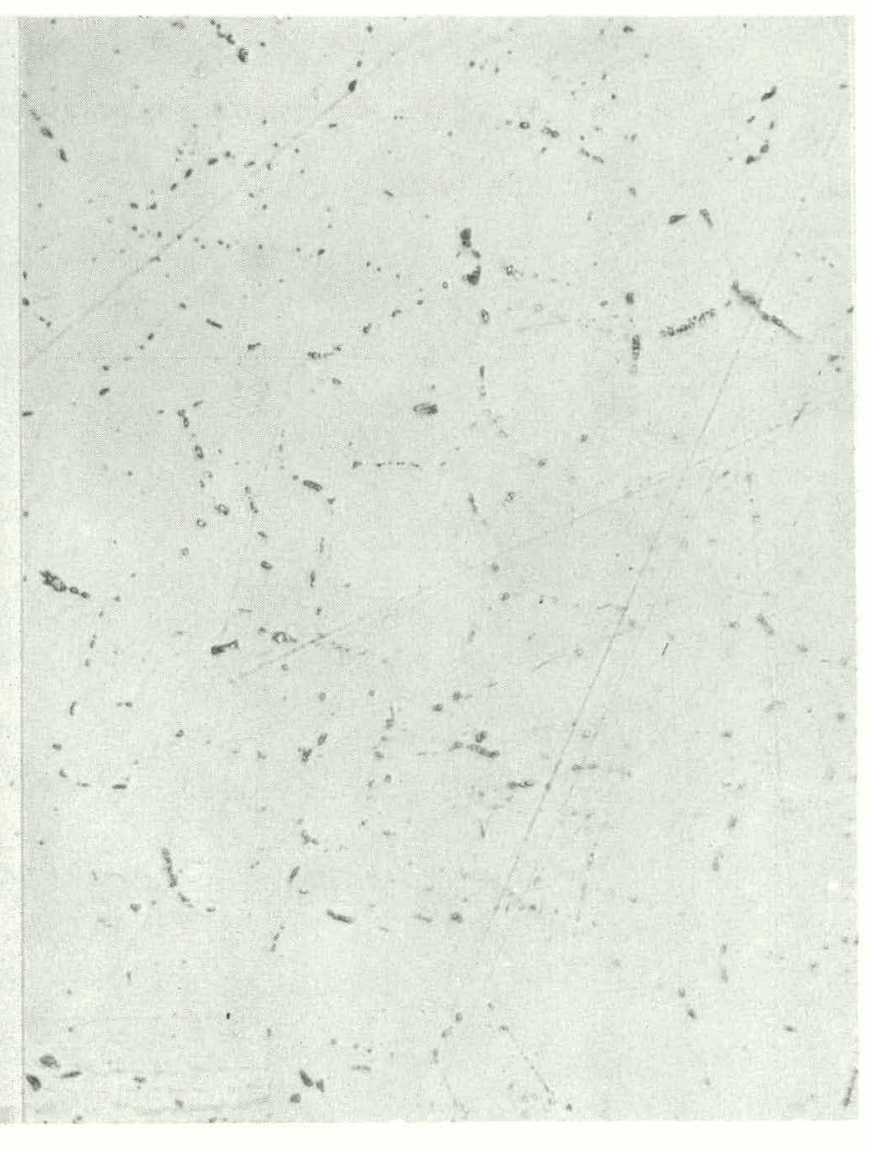

(d)

(a) MILL-ANNEALED STRUCTURE, IRRADIATED TO $6.7 \times 10^{21} \mathrm{n} / \mathrm{cm}^{2}\left(\right.$ En $>1 \mathrm{MeV}$ ) AND TESTED AT $0.0002 \mathrm{~min}^{-1}$

(b) MILL-ANNEALED STRUCTURE, IRRADIATED TO $6.7 \times 10^{21} \mathrm{n} / \mathrm{cm}^{2}($ En $>1 \mathrm{MeV})$ AND TESTED AT $0.02 \mathrm{~min}^{-1}$

(c) and (d) CARBIDE-AGGLOMERATED STRUCTURE, IRRADIATED TO $3 \times 10^{21} \mathrm{n} / \mathrm{cm}^{2}$ (En $>1 \mathrm{MeV}$ ) AND TESTED AT $0.02 \mathrm{~min}^{-1}$ 


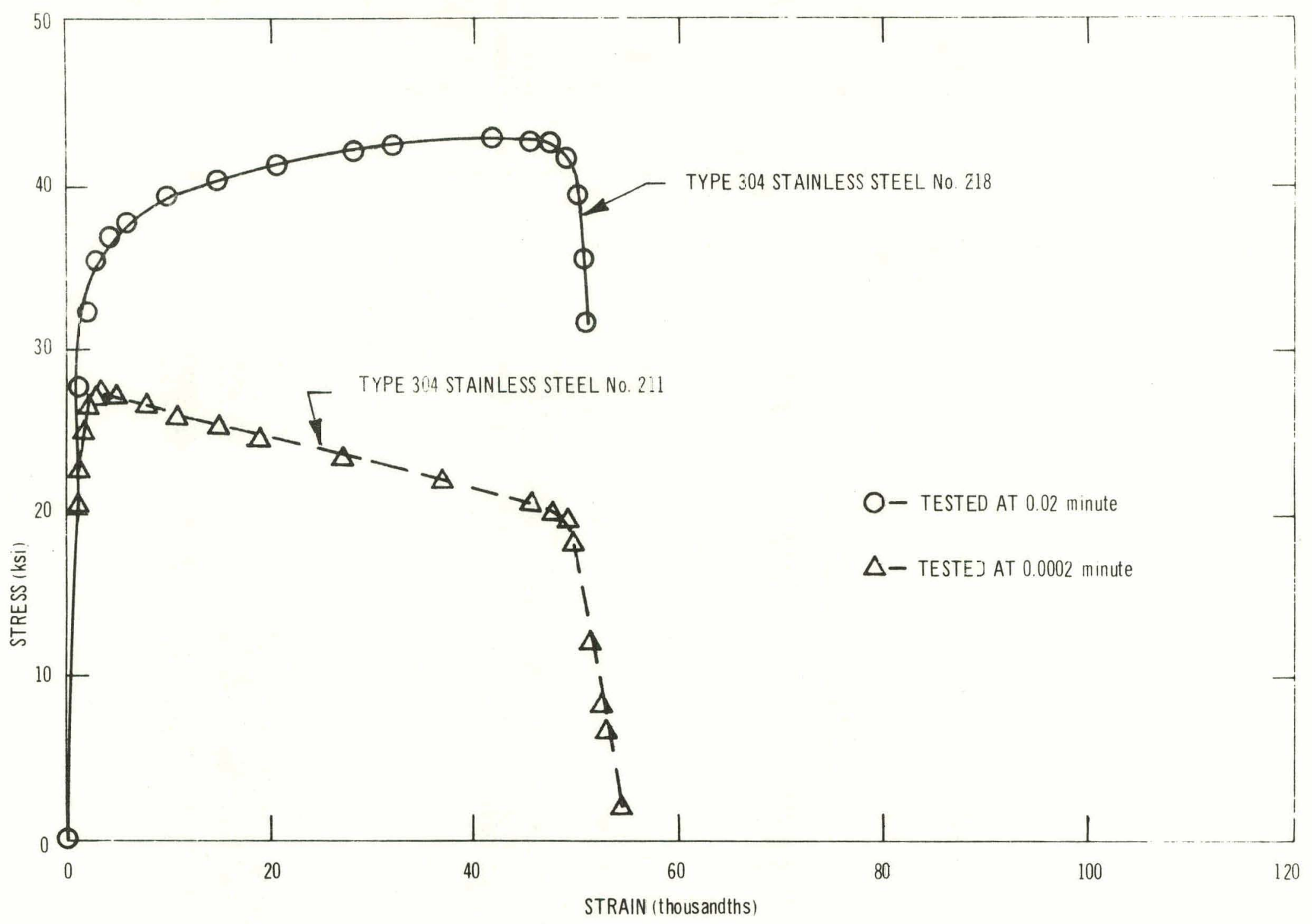

Figure 5-28. Effect of Strain Rate on the $1300^{\circ} \mathrm{F}$ Flow Curves of Mill-Annealed Type 304, Irrad ated at $>6.2 \times 10^{21}\left(E_{n}>\right.$ $1 \mathrm{MeV})$ 
radiation strengthening (as measured by increases in the $0.2 \%$ offset yield strength) arises from the interaction of cavities with dislocations (cavities modify the dislocation mobility).

Other transmission electron micrographs show that the gage section of the coupon tested at the strain rate of $0.0002 \mathrm{~min}^{-1}$ had a much lower dislocation density than the corresponding high strain rate specimen. However, the total deformation in the sample tested at $0.0002 \mathrm{~min}^{-1}$ was much lower than the deformation in the sample tested at $0.02 \mathrm{~min}^{-1}$. Deformation at low strain rates generally occurs in the grain boundaries, leading to incipient grainboundary cracking, whereas the grains are relatively undeformed.

Chromium-shadowed carbon replicas were made of the optical metallographic surfaces examined previously (Ref. 10). The specimen, which was in a mill-annealed condition prior to irradiation and tested at $0.02 \mathrm{~min}^{-1}$, is shown in Figure 5-30. A continuous carbide network is present in grain boundaries, with short intergranular cracks in some of the surface grain boundaries. No cracks were observed to be greater than one grain deep. Other micrographs show similar carbide precipitation in coherent and incoherent twin boundaries but no crack formation was noted.

Another specimen, in the same pre-irradiated condition but tested at $0.0002 \mathrm{~min}^{-1}$, shows the same general carbide distribution (Figure 5-31) as the more rapidly tested sample. However, because of the slow strain rate during the tensile test, surface cracks were found in every grain boundary. These cracks were much deeper than those observed in Figure 5-30, and often extended for several grains. As previously suggested, the differences in the stress strain curves for Type 304 may be associated with time-dependent propagation of incipient cracks in the slowly-strained sample, whereas localized and rapid propagation of cracks occurred in the sample tested at faster rates.

\subsubsection{Properties of Alloys in the Carbide- Agglomerated Condition}

The heat-treatment of as-received materials at $1650^{\circ} \mathrm{F}$ for 24 hours appears to have promise as a method to improve resistance to irradiation damage. The results for Type 304 in this carbide-agglomerated condition (Figure 5-32) suggest that some improvement in fracture strain may be realized at the higher fluence levels when compared with material in the mill-annealed condition. This trend is presently suggested by a singular set of data, and further confirmation is required for statistical significance.
The pre- and post-irradiation optical microstructures shown in Figure 5-33 provide some evidence to explain the differing tensile behavior of mill-annealed versus carbideagglomerated material. In the mill-annealed condition, the alloy was free of grain boundary carbides before irradiation but had a continuous grain boundary precipitation after irradiation. In the carbide-agglomerated condition, the microstructure consisted of large, discrete, intergranular carbides both before and after irradiation.

Chromium-shadowed carbon replicas were prepared from metallographic surfaces of irradiated tensile coupons and examined by electron microscopy techniques (Figure 5-34). The heat-treated specimen retained the preirradiation morphology and distribution of rounded discrete carbides in the grain boundary. These large carbides did not seem to have a detrimental effect on surface crack formation. The annealed material had a nearly continuous network of carbides in grain and twin boundaries, and short surface cracks were found intermittently. Thus, the detailed metallographic examinations shows that agglomerated carbides are retained in Type 304 after irradiation exposure, while the mill-annealed material developed a sensitized microstructure as expected in this temperature range.

The following thoughts are suggested to explain the apparent improvement in irradiation performance of carbide-agglomerated material:

a. As the matrix of the alloy is strengthened through the formation of voids, a greater share of the deformation must be borne by the grain boundaries through sliding. The existence of large, discrete particles in the boundary may act as a key between adjacent grains to reduce or minimize the initiation and growth of wedge-type cracks which normally occur under these circumstances.

b. A heat-treatment of this type has been shown (Ref. 1) to reduce effectively the concentration of undesirable tramp elements at the grain boundaries by providing preferred sites in the structure for the complex carbide. This would effectively increase the surface energy for fracture at the grain boundaries, thereby increasing the minimum shear stress required to initiate a crack, as defined by the Stroh relationship (Ref. 12).

c. The effective removal of supersaturated carbon from the lattice prior to irradiation may have beneficial effects, if the movement of carbon and the kinetics of carbide precipitation are intimately associated with the grain boundary embrittlement phenomenon (helium generation and movement). 


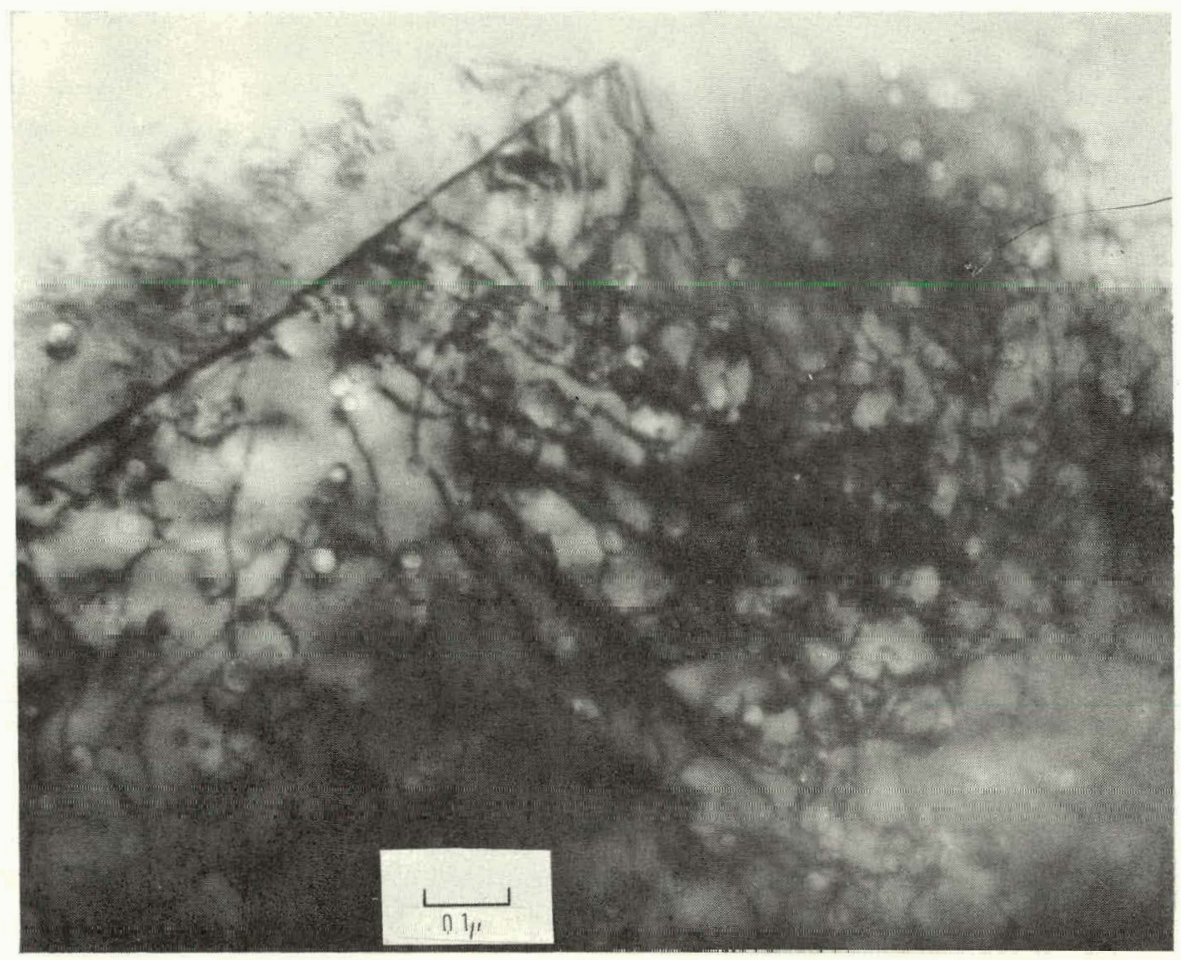

Figure 5-29. Transmission Electron Micrograph from Gage Section of Failed Specimen No. 218 (Mill-Annealed Type 304)

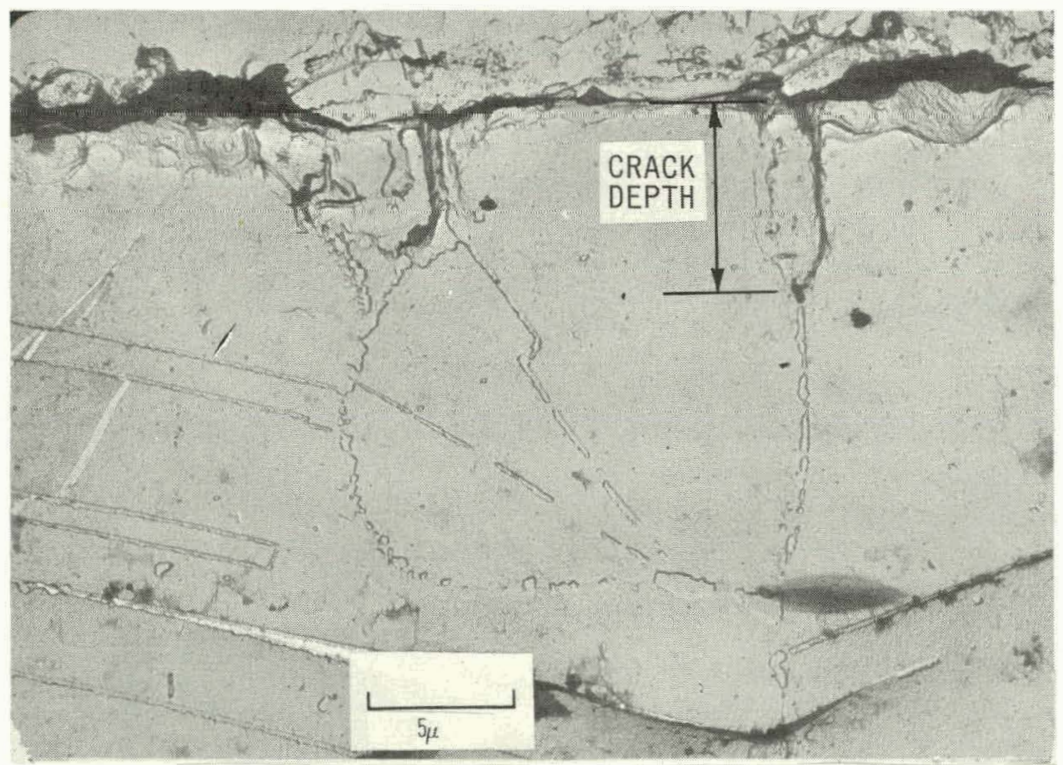

Figure 5-30. Surface Microstructure of Failed Specimen No. 218 (Mill-Annealed Type 304) 
GEAP-10066

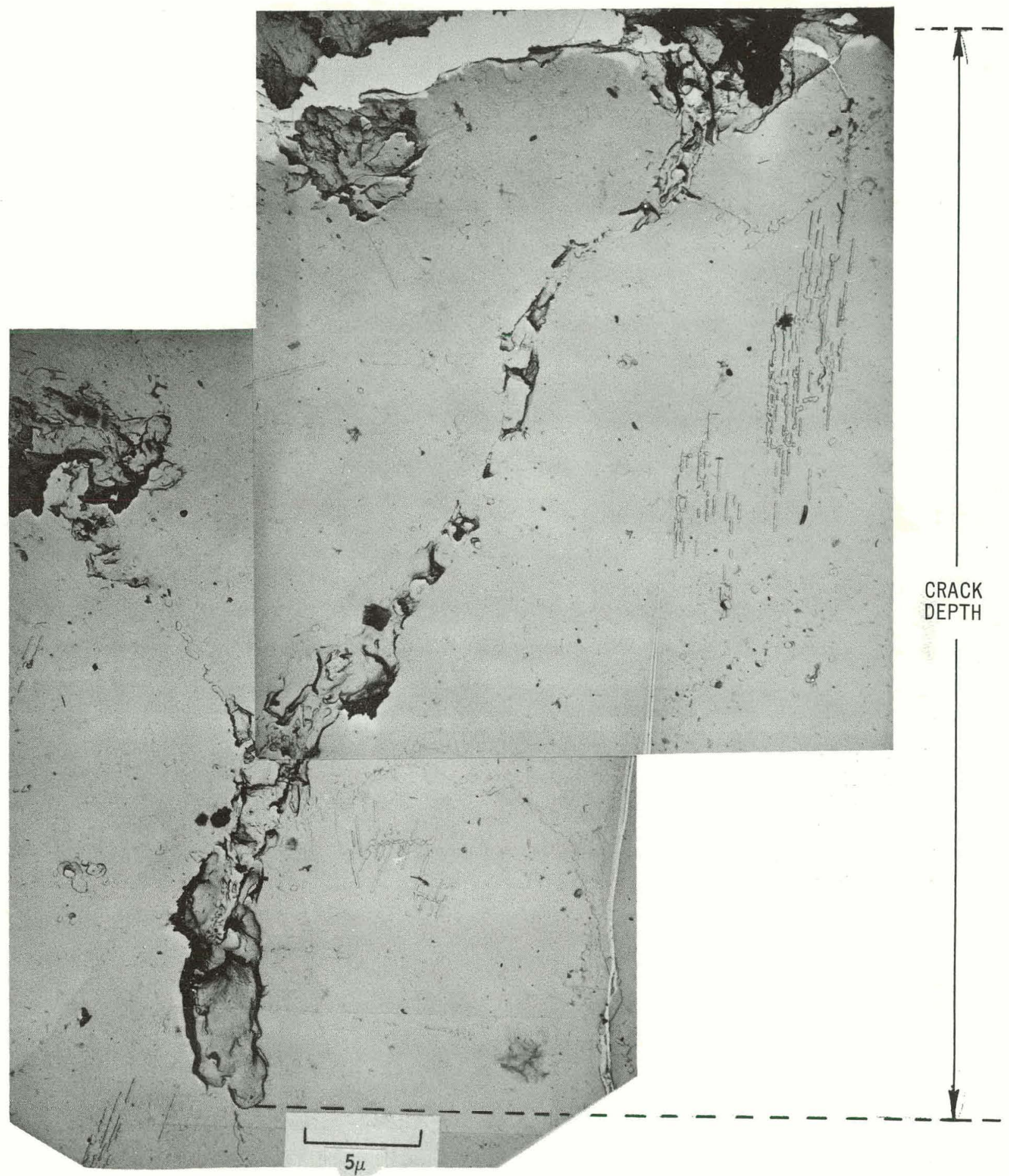

Figure 5-31. Surface Microstructure of Failed Specimen No. 211 (Mill-Annealed Type 304) 


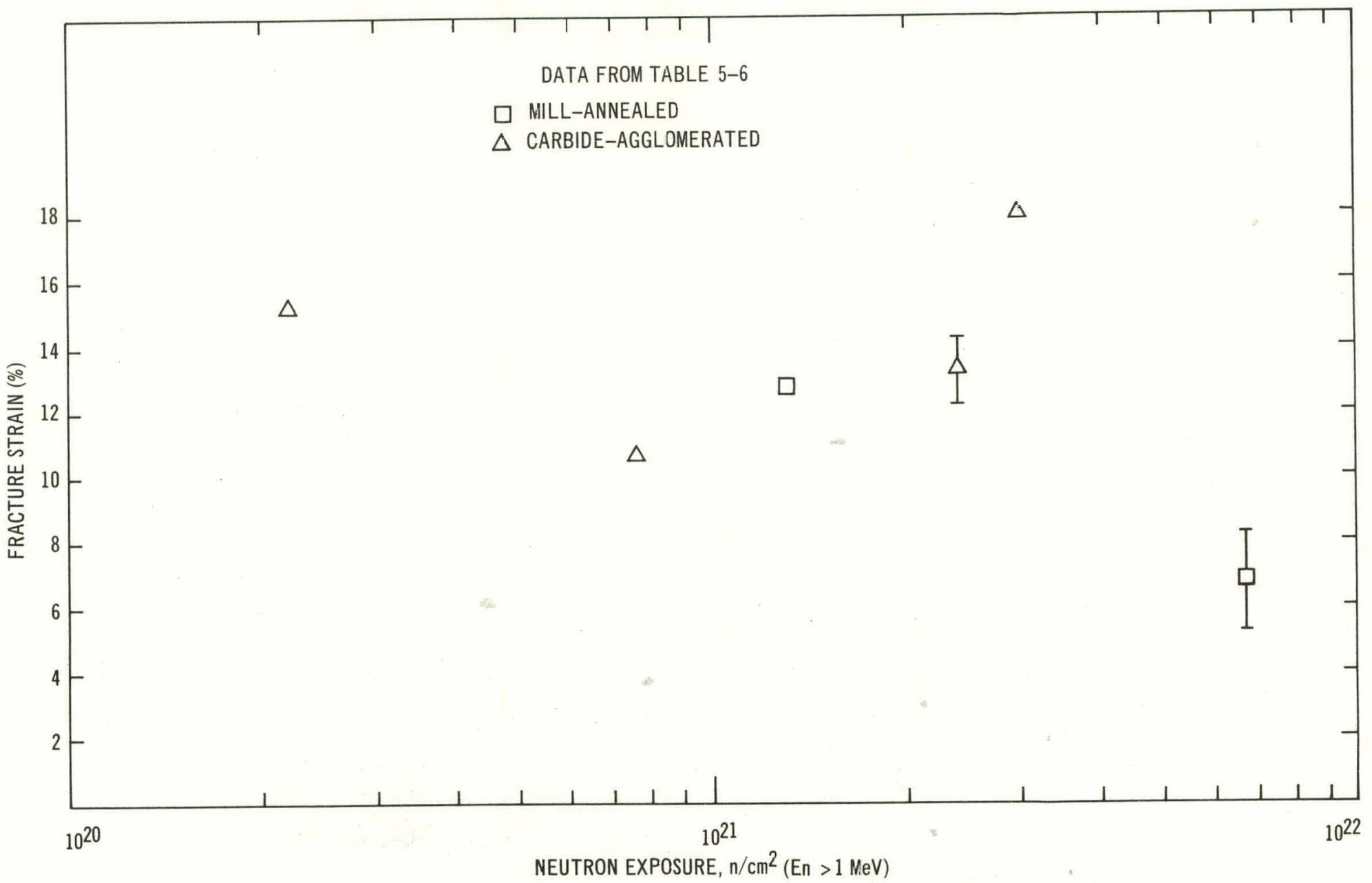

Figure 5-32. Post-Irradiation Strain Properties of Type 304 at $1300^{\circ} \mathrm{F}$ versus Fluence 


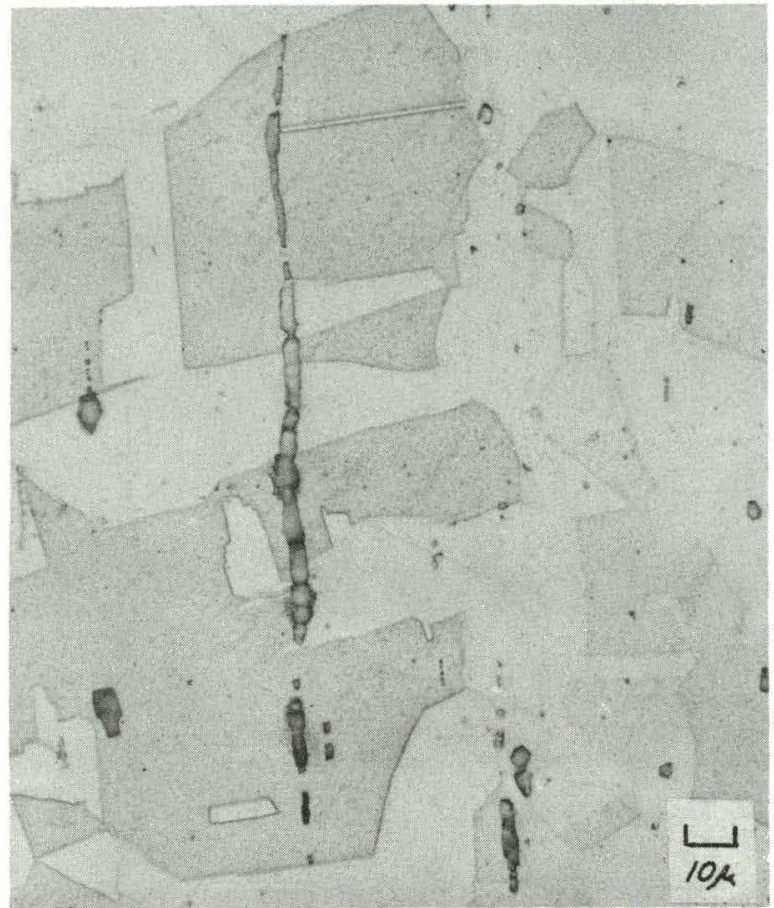

UNIRRADIATED

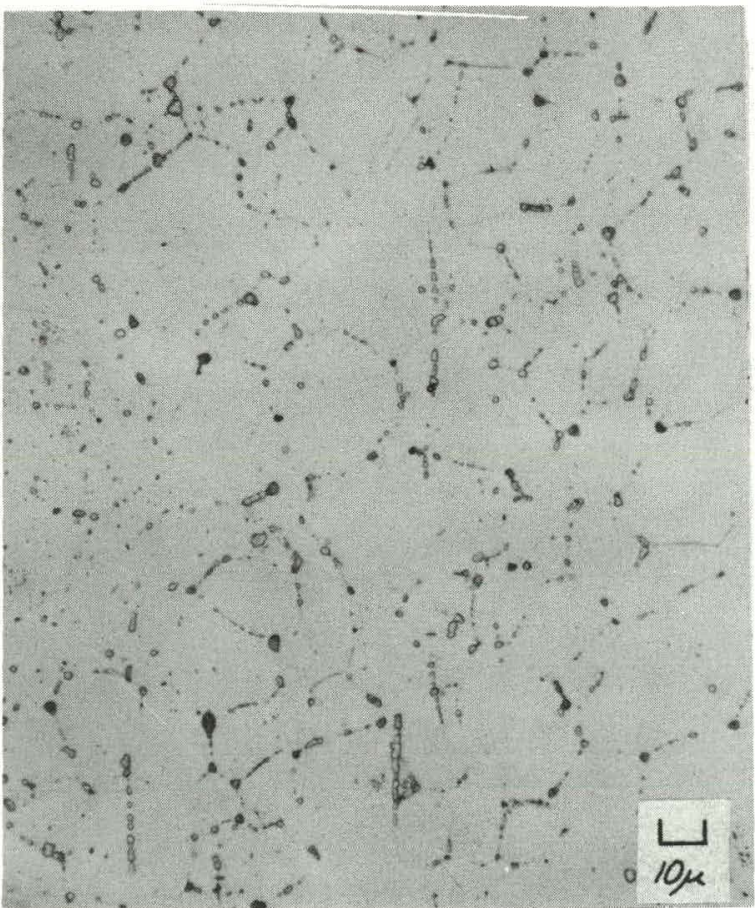

UNIRRADIATED

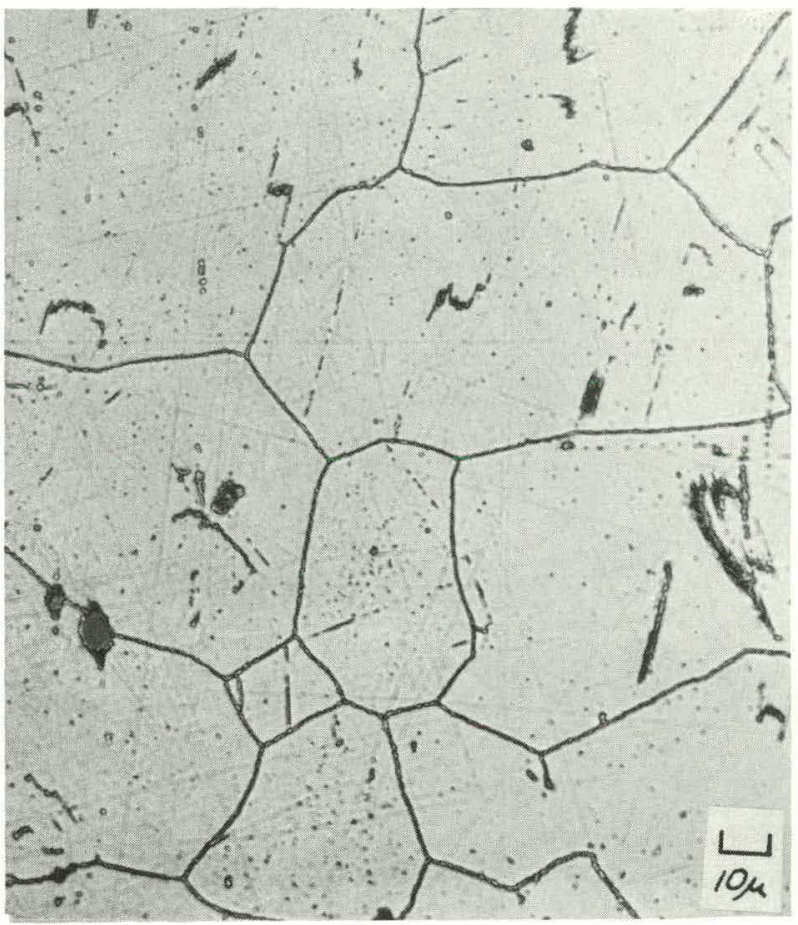

(a)

IRRADIATED

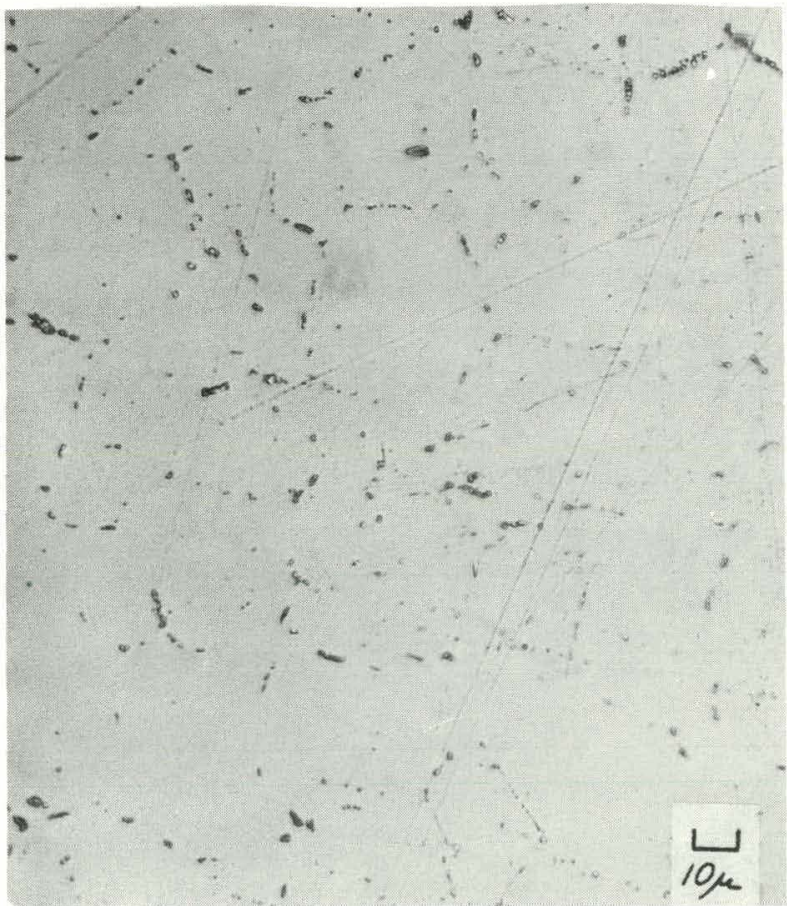

(b)

Figure 5-33. Comparison of Microstructure for (a) Mill-Annealed, and (b) Carbide-Agglomerated Type 304 in both Unirradiated and Irradiated Conditions 


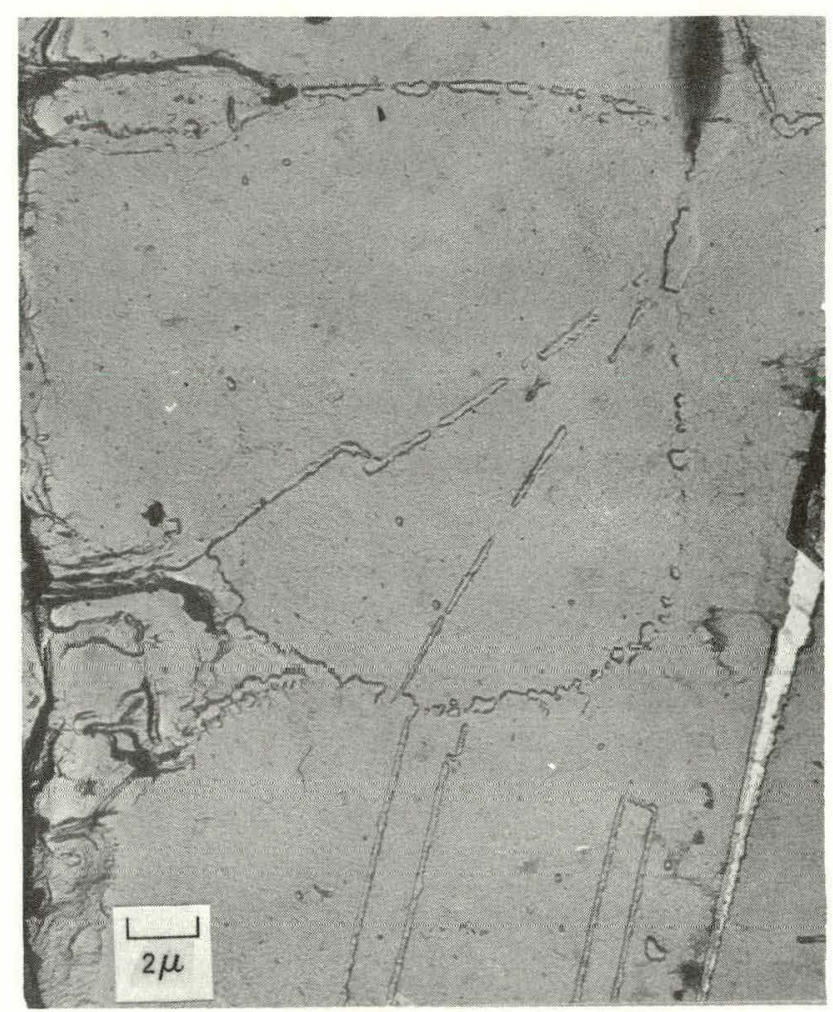

(a)

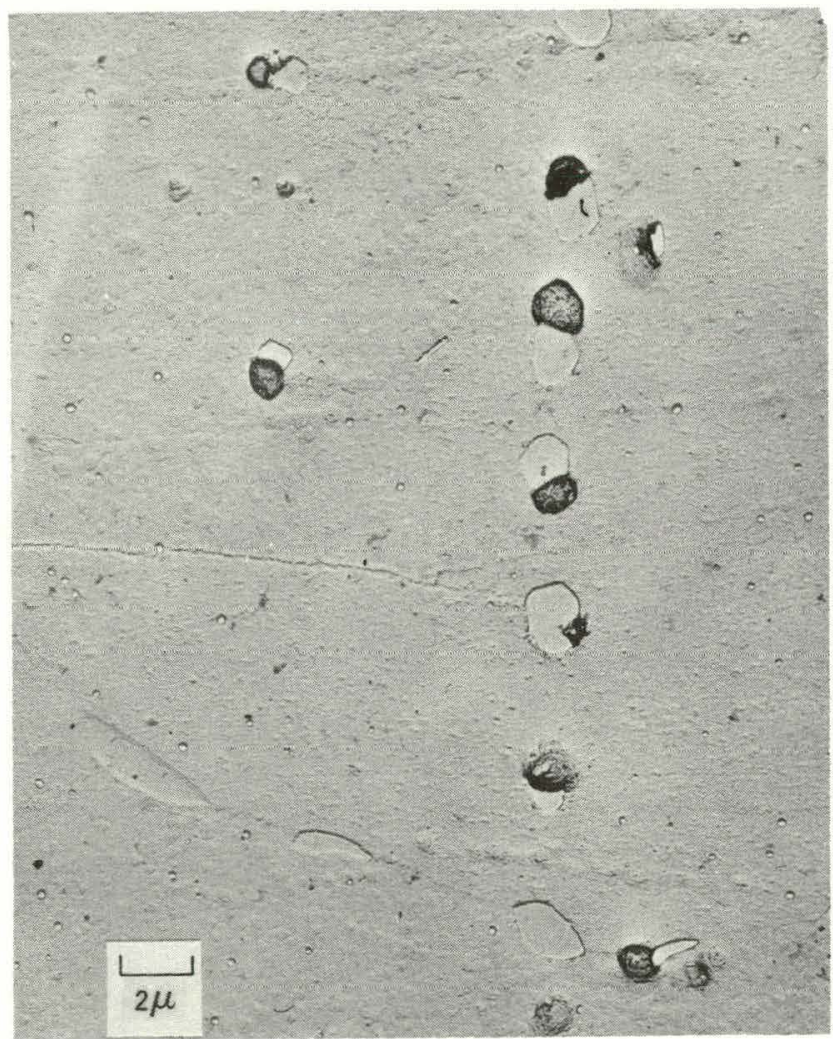

(b)

Figure 5-34. Replica Electron Micrographs of (a) Annealed, and (b) Carbide-Agglomerated Type 304 Irradiated in EBR-II 


\section{APPENDIX}

To rstatilish base mechanical properties from which the: effecels of irradiation could be determined, control samples ivere: given thermal treatments out-of-reactor to establish the effect of temperature exposure. The resuks of " " these studies are listed in the following table, for each of the alloys in the program. 
TENSILE PROPERTIES OF MILLANNEALED AUSTENITIC STAINLESS STEEL BEFORE AND AFTER THERMAL EXPOSURE

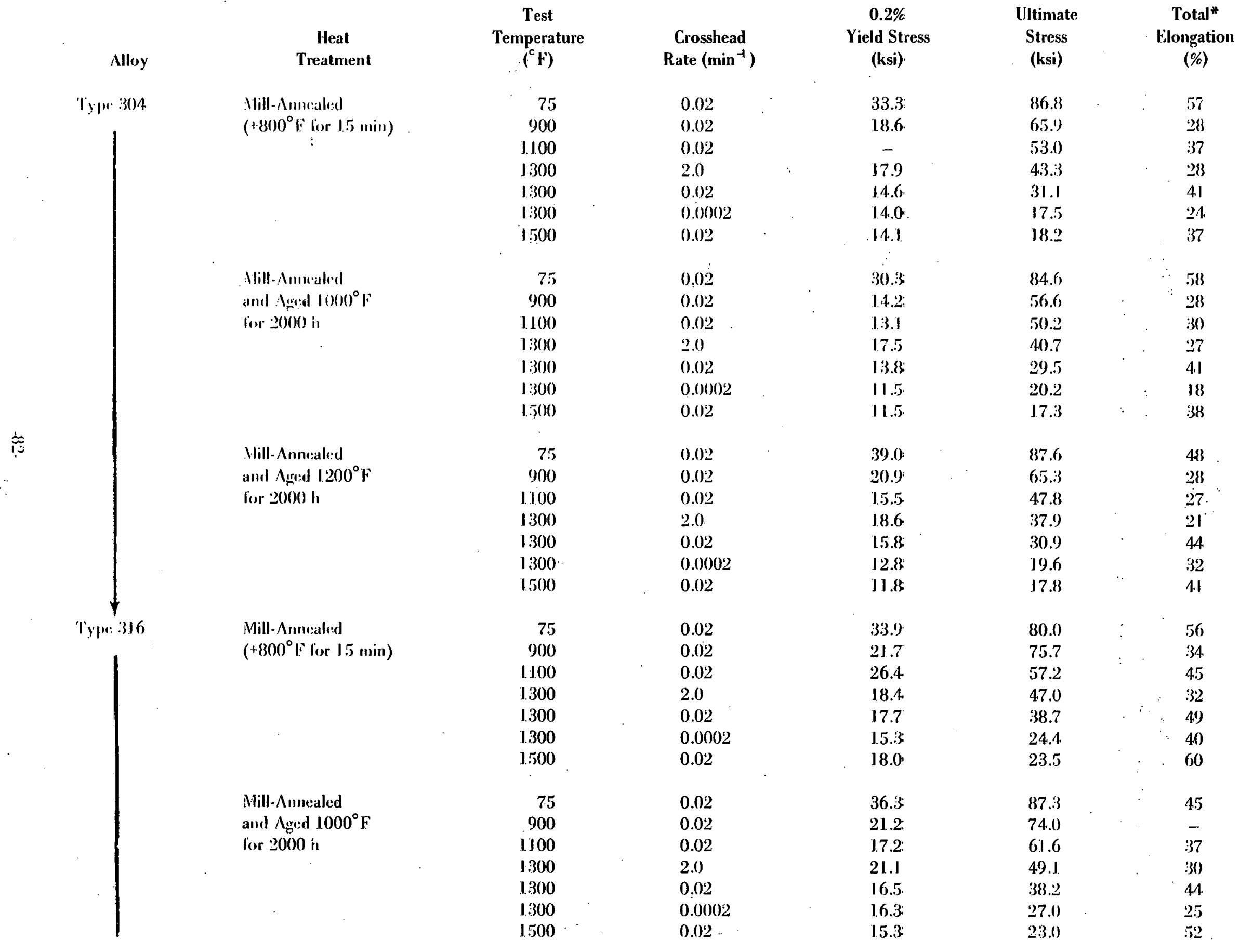


$\therefore \quad$ e

TENSILE PROPERTIES OF MILL-ANNEALED AUSTENITIC STAINLESS STEEL
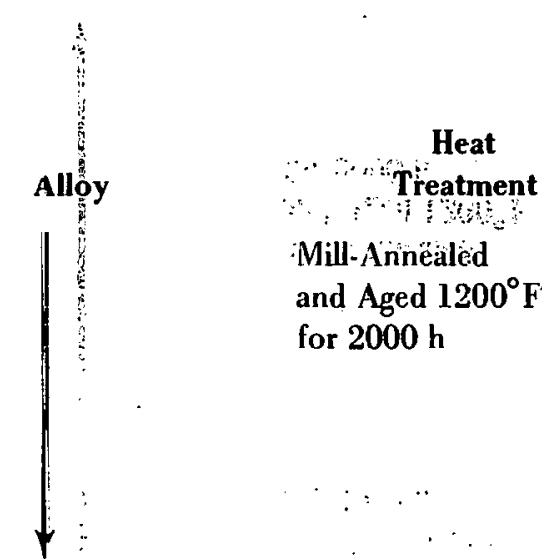

Mill-Annéalèd

and Aged $1200^{\circ} \mathrm{F}$

for $2000 \mathrm{~h}$

BEFORE AND AFTER THERMAL EXPOSURE

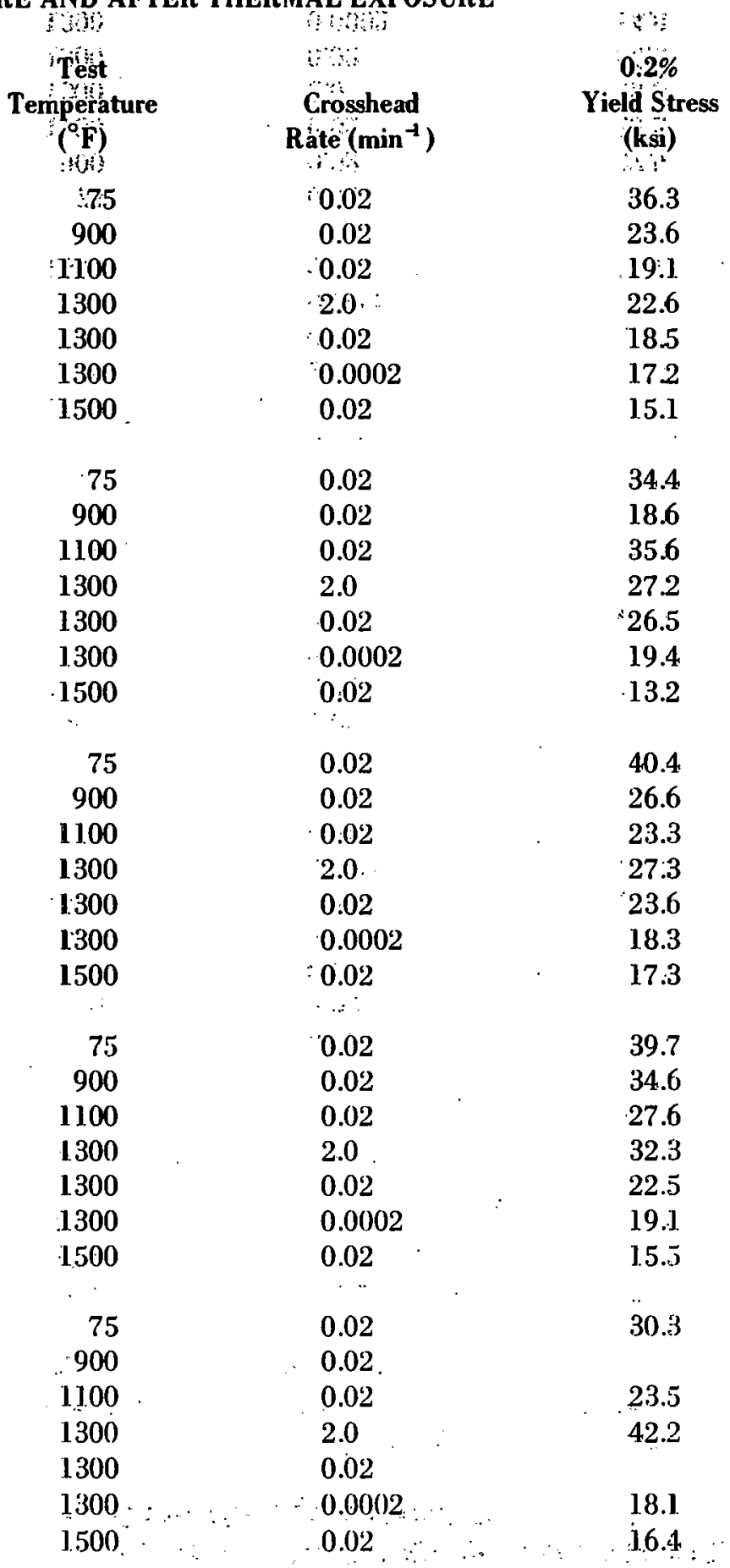

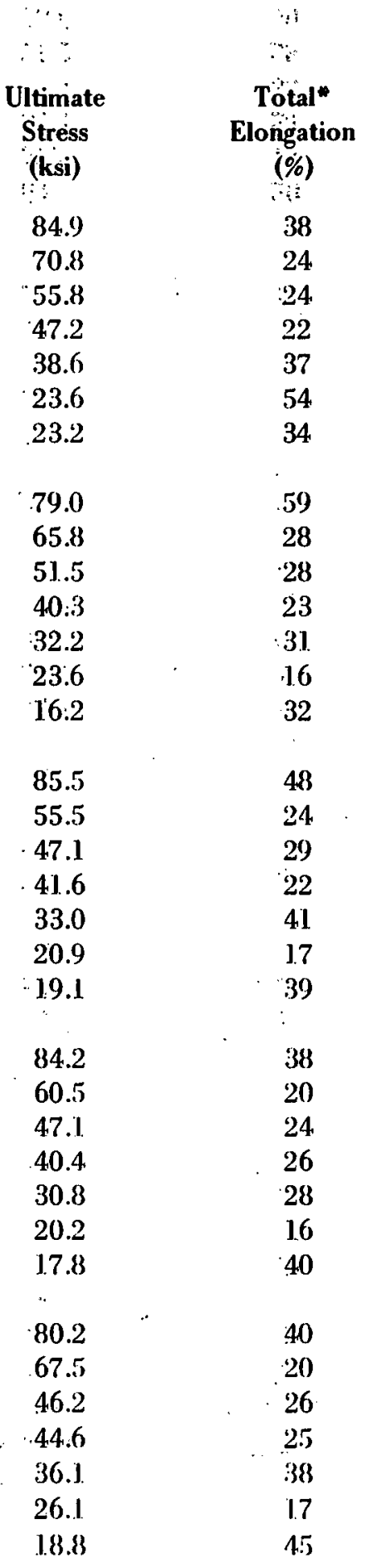

Mill-Annealed

and Aged $1200^{\circ} \mathrm{F}$

for $2000 \mathrm{~h}$

Mill-Annealed

Type 347

- $\left(+800^{\circ} \mathrm{F}\right.$ for $\left.15 \mathrm{~min}\right)$

16.4 
TENSILE PROPERTIES OF MILL-ANNEALED AUSTENITIC STAINLESS STEEL BEFORE AND AFTER THERMAL EXPOSURE

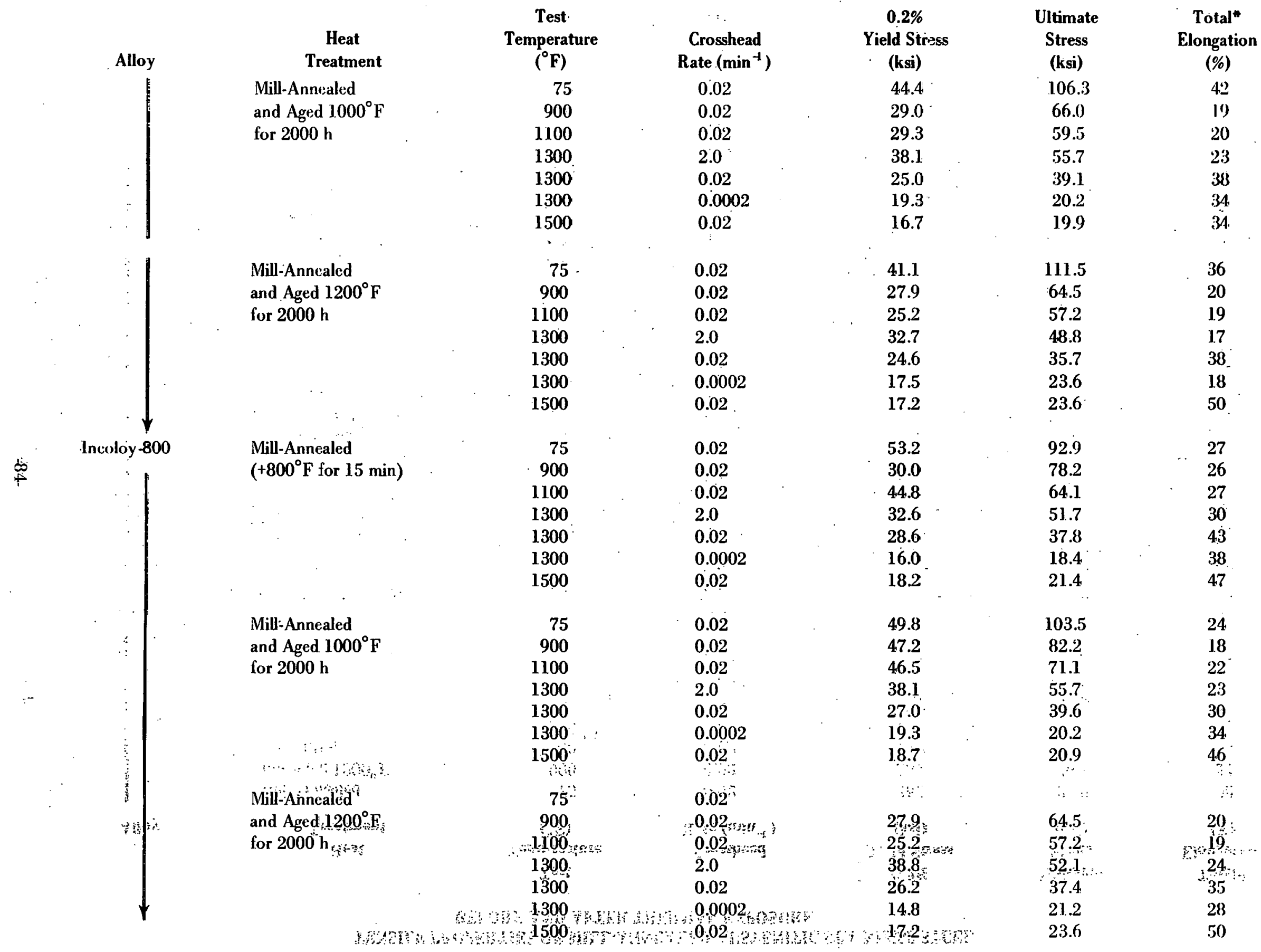




\section{REFERENCES}

1. Holmes, J. J., Robbins, R. E., Brimhall, J. L., and Mastel, B., "Elevated Temperature Irradiation Hardening in Austenitic Stainless Steel," Acta Met., 7, 16 (July 1968) 955.

2. Stiegler, J. O., Bloom, E. E., and Weir, J. R., "Electron Microscopy of Irradiated EBR-II Fuel Cladding," Trans. ANS, 1, 11 (June 1968) 146.

3. Cawthorne, C., and Fulton, E. J., Nature, 216 (November 11, 1967) 575.

4. Brager, H., and Robbins, R. E., "Stabilized Cavities in Irradiated Austenitic Stainless Steel,"BNWL-SA-1701 (February 1968).

5. Rossin, A. D., "Dosimetry for Radiation Damage Studies," ANL-6828 (March 1964).

6. Withop, A., Hutchins, B. A., and Martin, G. C., "Analytical Procedures' and Application of Fluence
Determinations from EBR-II Flux Wires," GEAP-5744, (March 1969).

7. Holmes, J. J., and Irvin, J. E., Trans. ANS, 10, 2 (1967).

8. Kittel, J. H., BNWL-609, December 1967.

9. Murphy, W. F., and Strohm, H. E. Nuclear Applications, 4, 4, 1968.

10. "Sodium-Cooled Reactor, Fast Ceramic Reactor Development Program, Task L, May-July 1968," GEAP-5677.

11. "Sodium-Cooled Reactor, Fast Ceramic Reactor Development Program, Task L, August-October 1968," GEAP 5700.

12. Stroh, A. N., Proc. Royal Society, Ser A, 223, (1954) 404.

\section{ACKNOWLEDGMENTS}

The following individuals have made significant contributions to this report and are accorded special recognition: R. E. Smith and D. S. Vash of Vallecitos Nuclear Center (VNC), for optical metallography and mechanical testing of irradiated materials; U. E. Wolff of VNC, for electron microscopy; W. J. Wagner and A.
Montes, for optical metallography of unirradiated alloys; D. H. Frisby, for mechanical testing of unirradiated materials; and $H$. Saethre, for heat-transfer analysis. In addition, the constructive review of this report by C. N. Spalaris, and the contribution of N. I. Brown toward computations and graphical analysis, are gratefully acknowledged.

\section{DISTRIBUTION LIST}

Director, Contracts Division

U. S. Atomic Energy Commission

San Francisco Operations Office

2111 Bancroft. Way

Berkeley, California 94704

Chief, California Patent Group

U. S. Atomic Energy Commission

San Francisco Operations Office

P. O. Box 808

Livermore, California 94551

Division of Reactor Development and Technology

U. S. A tomic Energy Commission

Washington, D. C. 20545

Attn: Asst. Director for Reactor Engineering
2 Division of Reactor Development and Technology

U. S. Atomic Energy Commission

Washington, D. C. 20545

Attn: M. J. Whitman

Asst. Director for Program Analysis

Division of Reactor Development and Technology

1 U. S. Atomic Energy Commission

Washington, D. C. 20545

Attn: A. Giambusso

Asst. Directur for Project Mgmt

(Attn: R. Sweek, G. Wensch, J. Morabito)

Division of Reactor Development and Technology

2 U. S. Atomic Energy Commission

Washington, D. C. 20545

Attn: J. A. Lieberman

Asst. Director for Nuclear Safety 


\section{DISTRIBU'IION LIST (Continued)}

Division of Reactor Development and Technology U. S. Atomic Energy Commission

Washington, D. C. 20545

Attn: J. A. Lieberman

Asst. Director for Nuclear Safety

Division of Reactor Development and Technology

U.S. Atomic Energy Commission

Washington, D. C. 20545

Attn: J. W. Crawford

Asst. Director for Plant Engineering

Uivision of Reactor Development äñd Technology

U.S. Atomic Energy Commission

Washington, D. C. 20545

Attn: K. H. Steel

Division of Naval Reactors

Division of Reactor Development and Technology

U.S. Atomic Energy Commission

Washington, D. C. 20545

Attn: E. E. Sinclair

Asst. Director for Reactor Tech.

(Attn: J. M. Simmons; I. Zartman)

RDT Site Office

U.S. Atomic Energy Commission

c/o General Electric Company

310 DeGuigne Drive

Sunnyvale, California

Attn: J. V. Levy

LMFBR Program Office

Argonne National Laboratory

9800 South Cass Avenue

Argonne, Illinois 60439

Attn: A. Amorosi, Director

LMFBR Program Office

Argonne National Laboratory

9800 South Cass Avenue

Argonne, Illinois 60439

Attn: L. R. Kelman

Atomics International

P.O. Box 309

Canoga Park, California 91304

Attn: S. Golan
1 Director

Liquid Metals Information Center

P. 0. Box 309

Canoga Park, California 91305

The Babcock \& Wilcox Company

1 Atomic Energy Division

Lynchburg, Virginia 24501

Attn: M. W. Croft

Mr. L. W. Fromm, Manager

1000 MWe L.MFRR. Follow-@n Study Prnjest

1 Building 208

Argonne National Laboratory

9800 South Cass Avenue

Argonne, Illinois 60439

Mr. C. A.. Anderson, Project Mgr

1000 MWe LMFBR Follow-On Study

2 Westinghouse Electric Corporation

Advanced Reactors Division

Waltz Mill Site

P. O. Box 158

Madison, Pennsylvania 15663

FFTF Project

2 P. O. Box 220

Richland, Washington 99352

Attn: Configuration \& Data Management

W. P. Staker, Projcct Manager

1000 MWe LMFBR Follow-On Study

Combustion Engineering, Inc.

P. O. Box 500

1 Windsor, Connecticut 06095

RDT Senior Site Representative

Canoga Park Area Office

P. 0. Box 2325

San Diego, California 92112

1

RDT Senior Site Representative

Canoga Park Area Office

P. 0. Box 591

Canoga Park, California 91305

RDT Senior Site Representative

2 U.S. Atomic Energy Commission

Argonne National Laboratory

9800 South Cass Avenue

Argonne, Illinois 60439
2 


\section{DISTRIBUTION LIST (Continued)}

RI'T Sile Office:

I . . Atomic linergy Commission

Alomic Power Jevclopment Associates, Inc.

19.1 I lïst Street

Jetroil, Michigan 48226

RJ'T Senior Site Representative

()ak Ridge National Laboratory

P. (). Box X

Oak Ridge, Tennessee 37830

The Babcock \& Wilcox Company

Atomic Energy Division

l.ynchburg, Virginia 24501

Attn: S. H. Esleeck

RD'T Senior Site Representative

U.S. Atomic Energy Commission

P. O. Box 550

Richland, Washington 99352

RDT Site Representative

U.S. Atomic Energy Commission

Post Uffice Box 2108

Idaho Falls, Idaho 83401

RDT Site Representative

U.S. Atomic Energy Commission

United Nuclear Corporation

Grasslands Road

Elmsford, New York 10523

Attn: M. Napack

RDT Site Representative

U.S. Atomic Énergy Lommission

United Nuclear Corporation

Grasslands Road

Elmsford, New York 10523

Attn: A Strasser

Argonne National Laboratory

9800 South Cass Avenue

Argonne, Illinois 60439

Attn: J. H. Kittel

Argonne National Laboratory

9800 South Cass Avenue

Argonne, Illinois 60439

Attn: R. C. Vogel
1 Pacific Northwest Laburatory

P. O. Box 999

Richland, Washington 99352

Attn: E. A. Eschbach

Pacific Northwest Laboratory

$1 \quad$ P.O. Box 999

Richland, Washington 99352

Attn: E. A. Evans

University of California

1 Lawrence Radiation Laboratory

P. 0. Box 808

Livermore, California 94551

Attn: A. Rothman

$1 \quad$ Los Alamos Scientific Laboratory

P. O. Box 1663

Los Alamos, New Mexico 87544

Attn: R. D. Baker

1 Los Alamos Scientific Laboratory

P. O. Box 1663

Los Alamos, New Mexico 87544

Attn: D. B. Ilall

Los Alamos Scientific Laboratory

1 P. O. Box 1663

Los Alamos, New Mexico 87544

- Altu: J. C. Clifford

Scientific Laboratory

P. O. Box 1663

Los Alamos, New Mexico 87544

1 Attn: Reports Lihrarian

Westinghouse Electric Corporation

Bettis Atomic Power Laboratory

P. O. Box 79

West Mifflin, Pennsylvania

Attn: E. J. Kreh

3

Oak Ridge National Laboratory

P. O. Box X

Oak Ridge, Tennessee 37830

Attn: J. E. Cunningham

1.

Brookhaven National Laboratory

Upton, New York 11973

Attn: O. E. Dwyer 


\section{DISTRIBUTION LIST (Continued)}

Battelle Memorial Institute

Columbus Laboratories

505 King Avenue

Columbus, Ohio 43201

Attn: D. Keller

Atomics International

P. O. Box 309

Canoga Park, California 91304

Attn: H. Pearlman

Atomics International

P. O. Box 309

Canoga Park, California 91304

Attn: FBR Project Manager

$$
\text { (R. J. Re.eley) }
$$

Dow Chemical Company

Rock Flats Division

P. O. Box 888

Golden, Colorado 80401

Attn: R. D. Forest

Scientific Representative

U.S. Atomic Energy Commission

American Embassy

APO San Francisco 96503

U.S. AEC Scientific Representative

United States Embassy

Paris, France

APO New York 09777

Senior U.S. AEC Representative

U.S. Mission to the European Communities United States Embassy

Brussels, Belgium

Division of Technical Information Ext.

U.S. Atomic Energy Commission

P. O. Box 62

Uak Kidge, 'I'ennessee 37831

Dr. John C. Woodhouse

1 Guest Lane

Wilmington, Delaware 19809

Power Reactor Development Corp.

1911 First Street

Detroit, Michigan 48226

Attn: W. J. McCarthy
1

Argonne National Laboratory

Idaho Division

P. O. Box 1096

Idaho Falls, Idaho 83401

Attn: F. W. Thalgott

1 Detroit Edison Company

1911. First Street

Detroit, Michigan 48226

Attn: A. S. Griswold

1 Atomic Power Development Associates

1911 First Street

Detroit, Michigan 48226

Attn: A. A. Shoudy

Combustion Engineering, Inc.

I. Nuclear Division

Prospect Hill Koad

Windsor, Connecticut 06095

Attn: W. P. Chernock

The Bahcock \& Wilcox Company

1 Atomic Energy Division

Lynchburg, Virginia 24501

Attn: H. S. Barringer

General Atomic

1 P. O. Box 608

San Diego, California 92112

Attn: D. B. Coburn

'I'he Bahcock \& Wilcox Company

1

Alliance Research Center

Alliance, Ohio 44601

Attn: D. Koch

Westinghouse Electric Corporation

50

Advance Reactors Division

P. O. Box 217

Cheswick, Pennsylvania 15024

Attn: W. E. Kay

1 Nuclear Materials \& Equipment Corp.

Plutonium Laboratory

Leechburg, Pennsylvania 15656

Attn: William J. Ross

1

U. S. AEC Scientific Representative

United States Embassy

London, England
1

1

1

1

].

1

1

1

$\mathbf{l}$

1 


\section{DISTRIBUTION LIST (Continued)}

S. F. Stachura Villa l'lein (iel Quartier Roussier Nix-en-Provence 13 - France

S. Visner Nuclear Division

Combustion Engineering, Inc. P. O. Box 500

Windsor, Connecticut 06095
1 W. B. Cottrell, Director

Oak Ridge National Laboratory

P. O. Box $Y$

Oak Ridge, Tennessee 37830

2

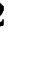

